\title{
$(4)$
}

UNIVERSIDAD PERUANA DE CIENCIAS APLICADAS

FACULTAD DE NEGOCIOS

PROGRAMA ACADÉMICO DE ADMINISTRACIÓN DE EMPRESAS

\section{Factores que afectan la rotación de los asesores telefónicos en los Centros de Contacto de Lima Metropolitana}

\author{
TESIS \\ Para optar el grado académico de título de Administración de Empresas \\ AUTORES: \\ Hoyos Saavedra, Fanny Carolina (0000-0001-8833-6534) \\ Polo Portilla, Giovanna Julissa ～(0000-0002-3315-8790) \\ ASESORES: \\ Chacón Resino, Ramón \\ (0000-0003-0937-1089) \\ Ikeda Tsukazan, Midori \\ (0000-0003-2466-7232)
}

Lima, 24 de noviembre de 2018 
DEDICATORIA

El presente trabajo se lo dedico a mi familia, quienes me apoyaron a seguir cumpliendo con mis metas personales y profesionales; a mi compañera de tesis por su comprensión, además de aprender a trabajar en equipo en el cumplimiento de esta meta profesional.

Fanny Hoyos.

El presente trabajo se lo dedico a mi familia, quienes confiaron y me apoyaron de manera incondicional; a mi compañera de tesis por su amistad y por cada palabra motivadora. A todas las personas que nos motivaron con sus palabras y conocimientos para seguir con la elaboración de este estudio. Giovanna Polo. 
AGRADECIMIENTOS

Esta investigación es el resultado de nuestro esfuerzo y compromiso, con la exigencia y la guía constante de nuestra asesora Midori Ikeda y luego del asesor Ramón Chacón, quienes nos brindaron sus conocimientos para poder desarrollar este estudio.

Alumnas 


\section{RESUMEN}

El presente trabajo de investigación tiene como objetivo identificar los factores que afectan la rotación de asesores telefónicos en los Centros de Contacto de Lima Metropolitana. El planteamiento y desarrollo de este estudio se basa en la siguiente interrogante: ¿Cuáles son los factores laborales que afectan la rotación de asesores telefónicos en los Centros de Contacto de Lima Metropolitana? Para esta investigación, se seleccionaron algunos Centros de Contacto en los que se tuvo mayor acceso para la recolección de testimonios.

Se utilizó el diseño exploratorio - descriptivo, con el fin de reunir información acerca del tema estudiado. Los sujetos de la muestra no probabilística fueron principalmente, los asesores telefónicos.

Para su análisis se utilizó la herramienta de entrevistas de profundidad y la elaboración de una guía de preguntas semi estructuradas, divididas por categorías para cada segmento, y así, poder contrastar las hipótesis planteadas.

Para efectos de esta investigación, se consideró las variables de estudios: turnos de trabajo, condiciones contractuales y remuneración, que bien pueden ser unos de los factores que consideran los asesores telefónicos al momento de desvincularse.

Por lo tanto, se llega a la conclusión que las variables mencionadas en este estudio afectan significativamente la rotación de asesores telefónicos en los centros de contacto investigados en Lima Metropolitana.

Palabras claves: Turnos de trabajo, condiciones contractuales, remuneración y rotación de personal. 
Factors that affect the rotation of telephone consultants in the Contact Centers of Metropolitan Lima

\begin{abstract}
This research work is aimed at identifying the factors affecting the turnover of telephone consultants in Contact Centers located in the Lima Metropolitan Area.

The approach and development of this study are based on the following question: What labor factors do affect the turnover of telephone consultants in Contact Centers located in Lima Metropolitan Area? For this research, some Contact Centers to which there was a greater access were selected for the collection of testimonies.
\end{abstract}

The exploratory-descriptive design was applied for this research with a view to gather information about the subject matter studied. The subjects of the non-probability sample were mainly telephone consultants.

For the purpose of analysis, the in-depth interviewing was applied and a semi-structured interview guide, which questions were divided by categories for each segment, was elaborated. Consequently, the proposed hypotheses were able to be contrasted.

For the purposes of this research, the study variables included: work shifts, contractual conditions and remuneration, which may be factors considered by the telephone consultants when resigning from their job.

Finally, this research concludes that the mentioned variables affect in a significant manner the turnover of telephone consultants in the investigational Contact Centers located in the Lima Metropolitan Area.

Keywords: Work shifts, contractual conditions, remuneration and staff turnover. 


\section{ÍNDICE}

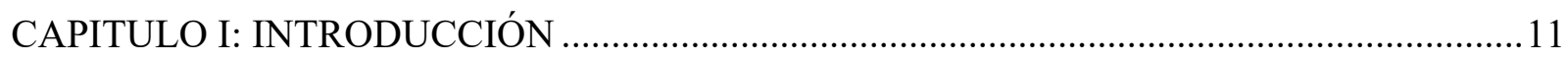

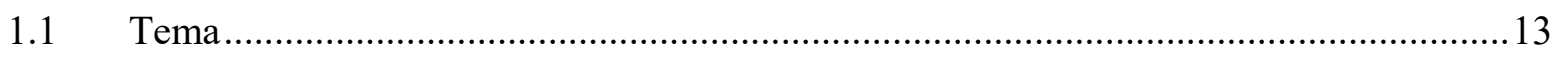

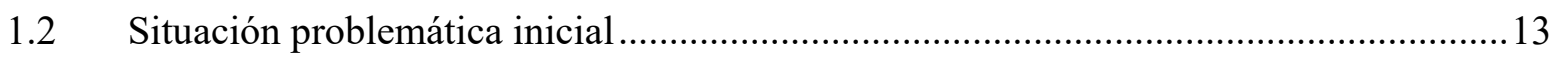

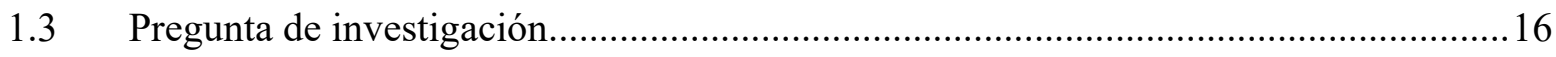

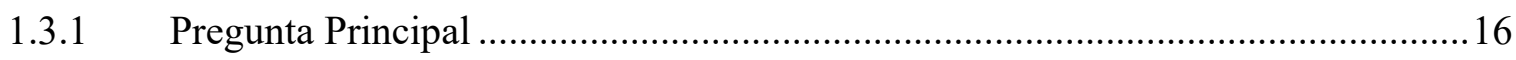

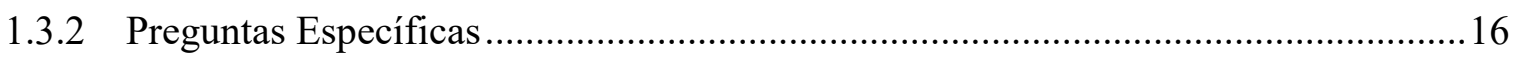

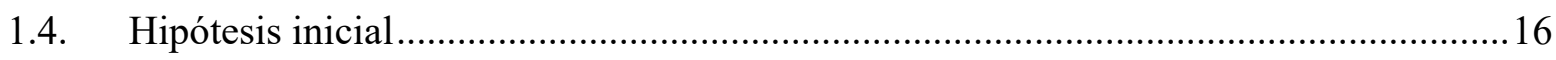

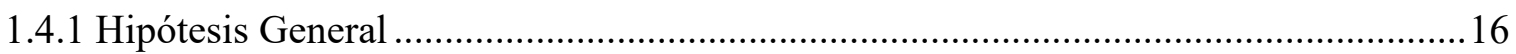

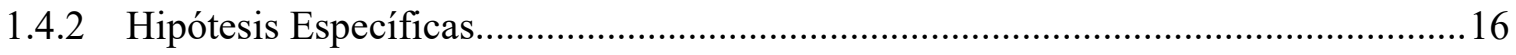

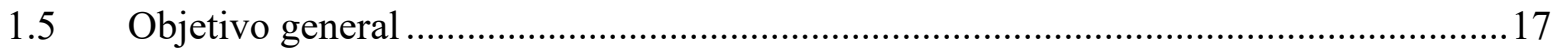

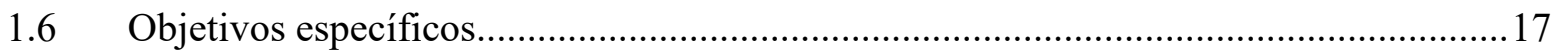

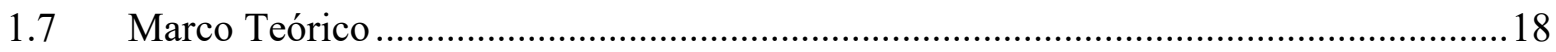

1.7.1 Definición de Call Center y Centros de Contacto ....................................................... 18

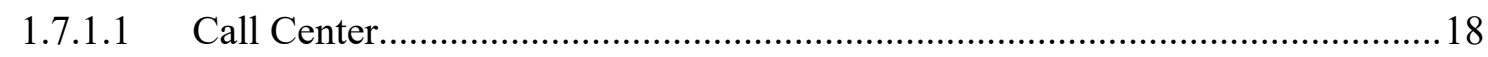

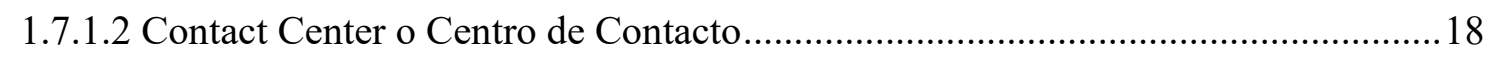

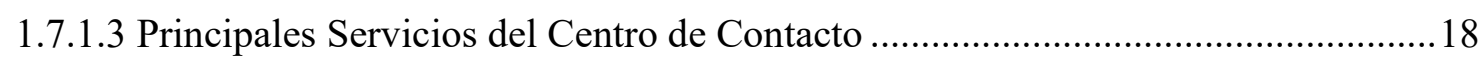

1.7.1.4 Demanda de Servicios en los Centros de Contacto en el Perú ............................... 19

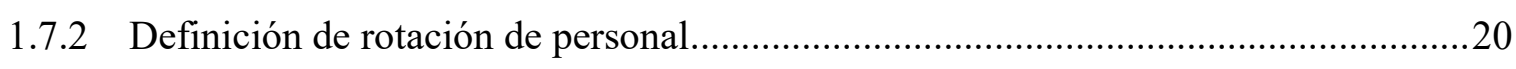

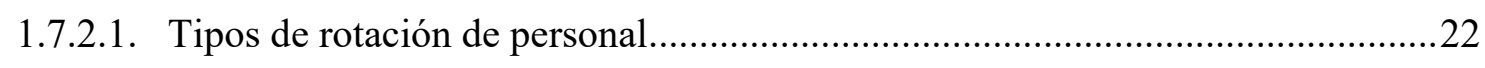

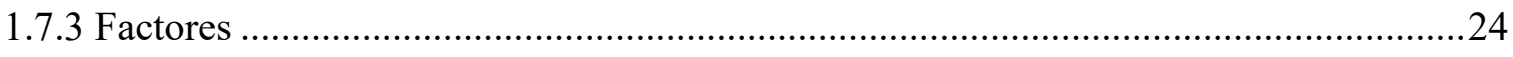

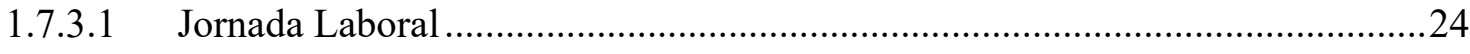

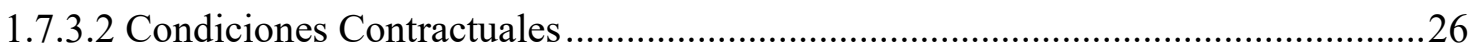

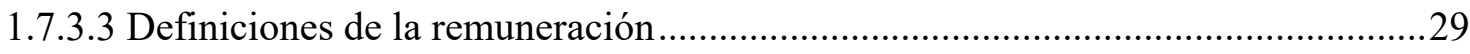

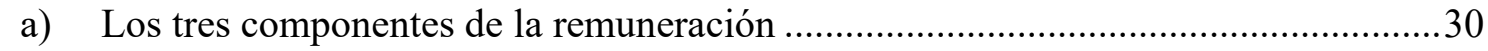

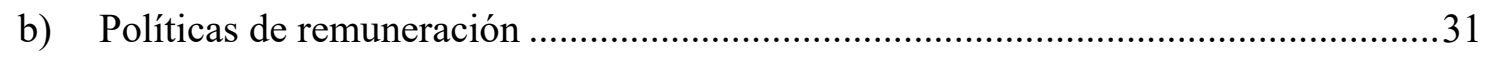

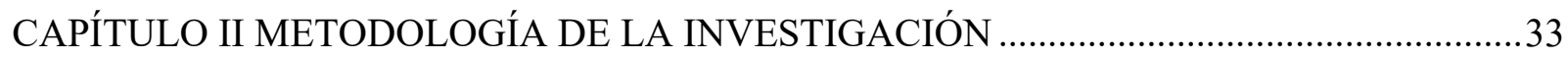

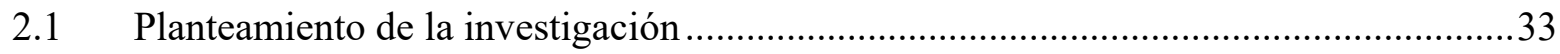




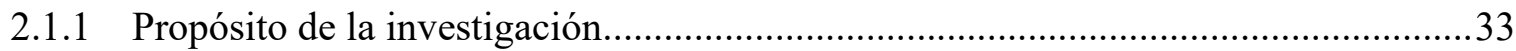

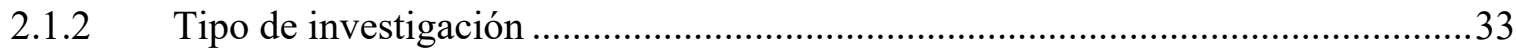

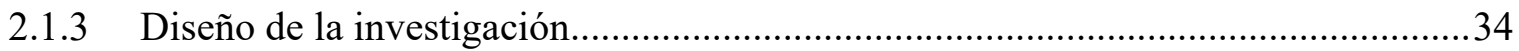

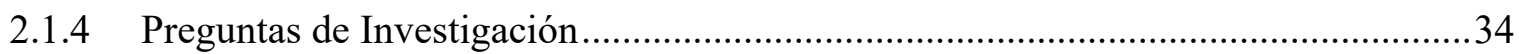

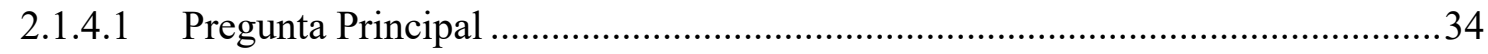

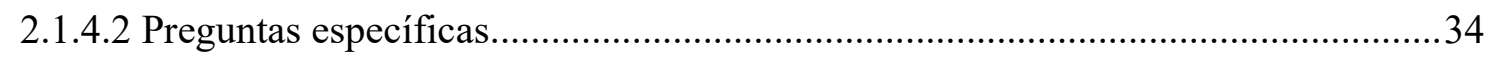

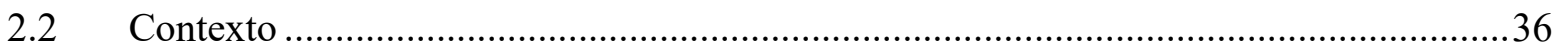

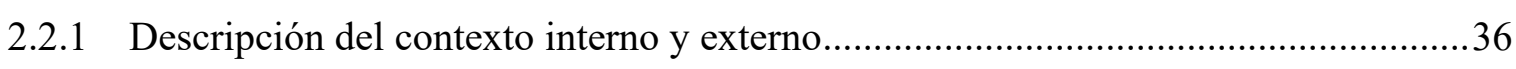

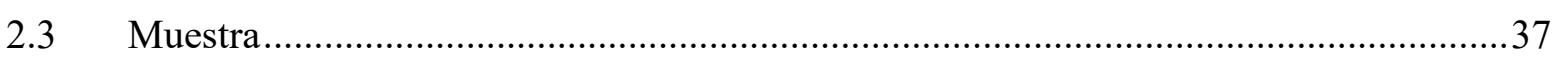

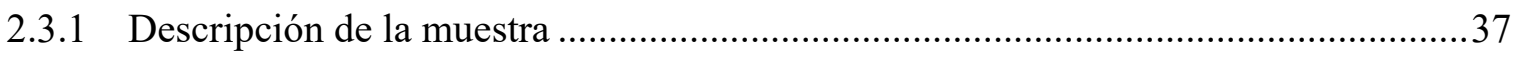

Segmento A. Asesores telefónicos de Centros de Contacto ...................................................

Segmento B. Asesores telefónicos de Centros de Contacto administrados por entidades bancarias. $\quad 38$

Segmento C. Supervisores, jefes o gerentes de Recursos Humanos. ................................38

Segmento D. Especialistas del sector de servicios de Centros de Contacto......................38

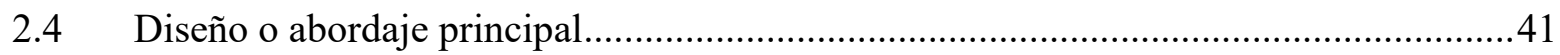

2.4.1 Identificación de la estructura de la entrevista de profundidad.................................41

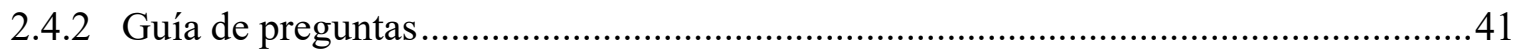

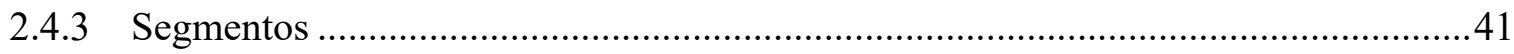

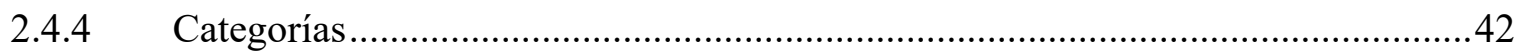

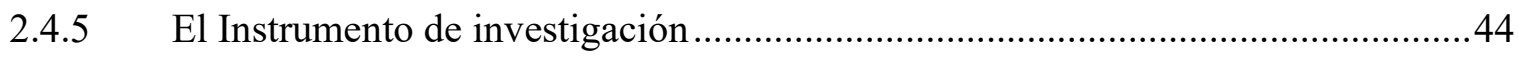

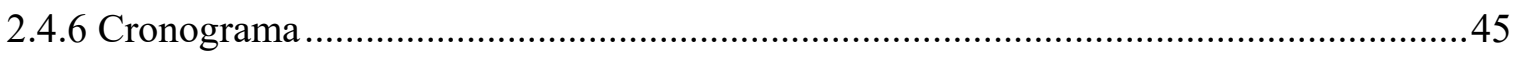

CAPÍTULO III ANÁLISIS DE DATOS Y RESULTADOS .....................................................47

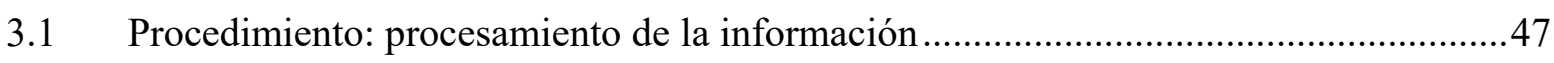

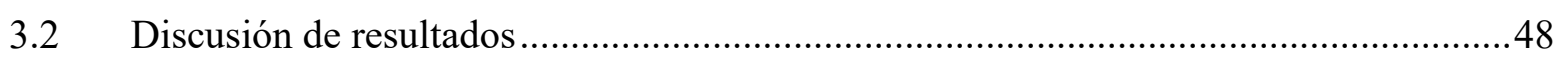

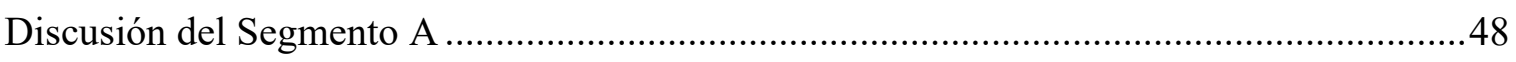

Asesores telefónicos de Centros de Contacto de Lima Metropolitana investigados..........48

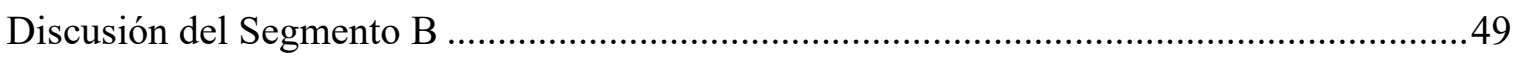

Asesores telefónicos de Centros de Contacto Administrado por entidades bancarias de Lima

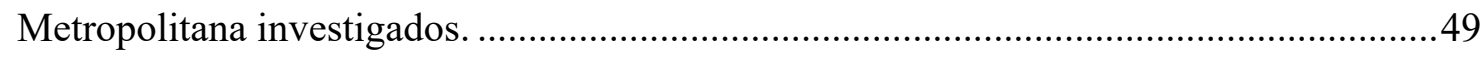

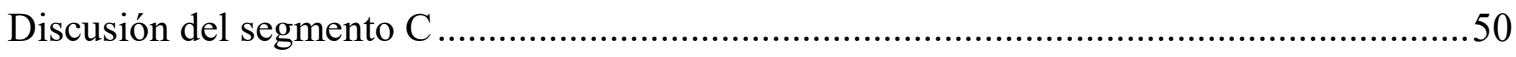


Supervisores, jefes o gerentes de Recursos Humanos....................................................50

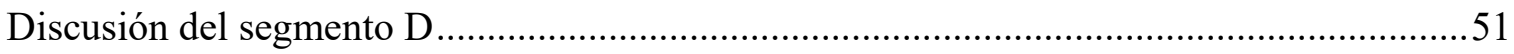

Especialistas del sector de Centros de Contacto de Lima Metropolitana ...........................51

CAPÍTULO IV HALLAZGOS, CONCLUSIONES Y RECOMENDACIONES .........................53

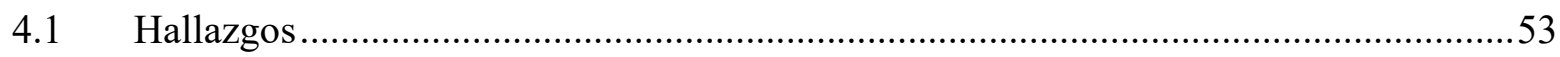

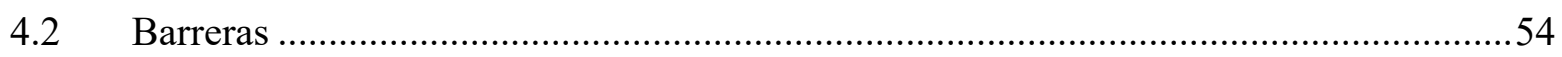

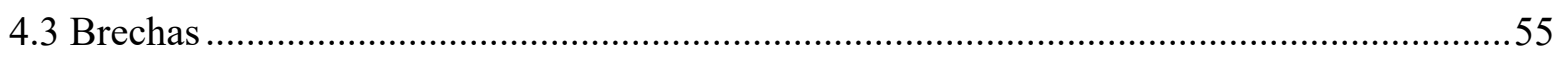

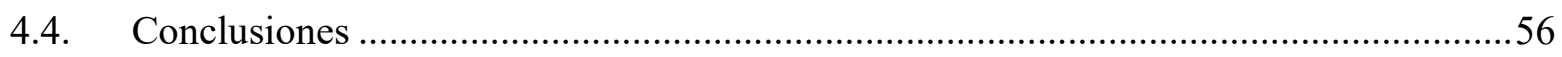

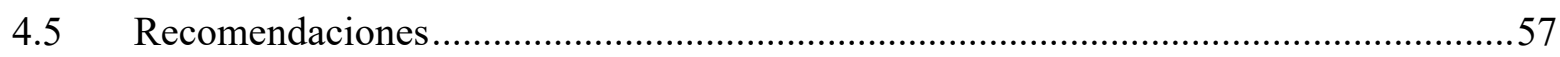

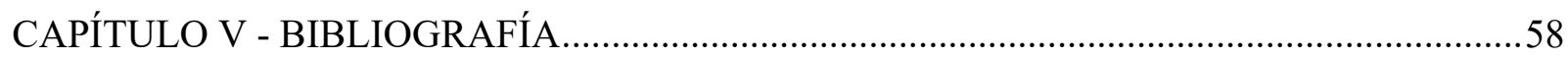

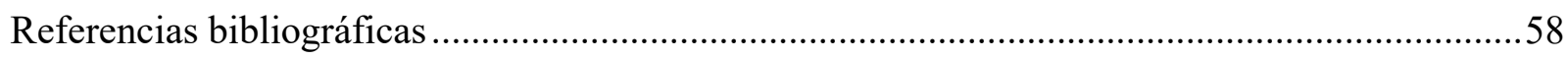

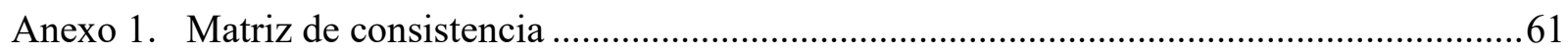

Anexo 2. Cuadro control de aplicación de entrevistas por cada segmento ...................................62

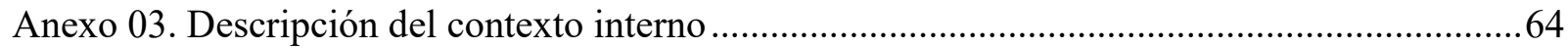

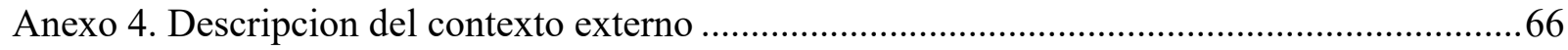

Anexo 5. Guía de preguntas para las entrevistas de profundidad a los asesores telefónicos de los centros de contacto y de centros de contacto administradas por entidades bancarias de Lima

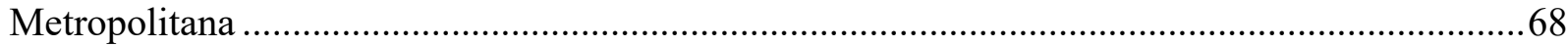

Anexo 6. Guía de preguntas para las entrevistas de profundidad a los supervisores, jefes y/o gerentes de los centros de contacto de Lima Metropolitana

Anexo 7. Guía de preguntas para las entrevistas de profundidad a los especialistas de los centros

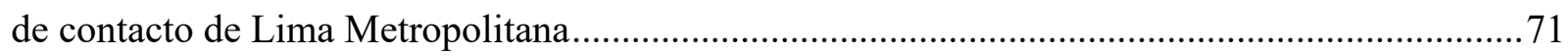




\section{Índice de tablas}

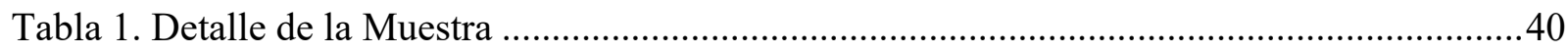

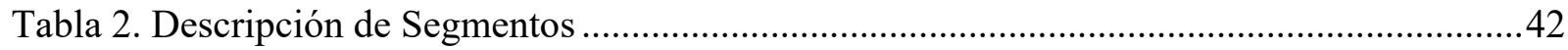

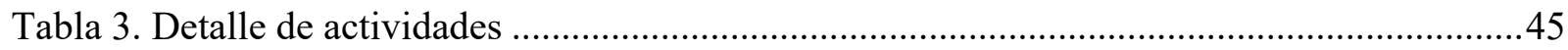

Tabla 4. Observaciones de la entrevista (Segmento A, Maritza, 42 años)....................................72

Tabla 5. Ficha de la entrevista (Segmento A, Maritza, 42 años) ................................................73

Tabla 6. Observaciones de la entrevista (Segmento A, Kevin, 26 años) ......................................74

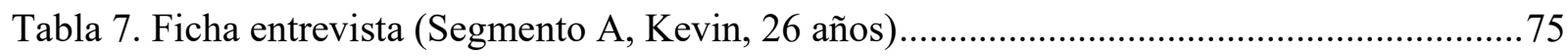

Tabla 8. Observaciones de la entrevista (Segmento A, María, 27 años).......................................77

Tabla 9. Ficha entrevista (Segmento A, María, 27 años) ............................................................78

Tabla 10. Observaciones de la entrevista (Segmento A, María, 27 años)...................................... 80

Tabla 11. Ficha de la entrevista (Segmento A, María, 27 años) ................................................... 81

Tabla 12. Observaciones de la entrevista (Segmento B, Frank, 30 años) ....................................82

Tabla 13. Ficha de la entrevista (Segmento B, Frank, 30 años) .................................................. 83

Tabla 14. Observaciones de la entrevista (Segmento B, Naya, 32 años) ......................................8

Tabla 15. Ficha de la entrevista (Segmento B, Naya, 32 años)................................................... 85

Tabla 16. Observaciones de la entrevista (Segmento C, Supervisor) ….......................................87

Tabla 17. Ficha de la entrevista (Segmento C, Supervisor) .......................................................... 88

Tabla 18. Observaciones de la entrevista (Segmento C, Supervisor) ...........................................90

Tabla 19. Ficha de la entrevista (Segmento C, Supervisor) ........................................................

Tabla 20. Observaciones de la entrevista (Segmento C, Gerente) …...........................................93

Tabla 22. Observación de la entrevista (Segmento C, Gerente) ..................................................95

Tabla 23. Ficha de la entrevista (Segmento C, Gerente).............................................................96

Tabla 24. Observaciones de la entrevista (Segmento D, Institución Privada) ...............................97

Tabla 25. Ficha de la entrevista (Segmento D, Institución Privada) .............................................98

Tabla 26. Observaciones de la entrevista (Segmento D, David Edery Muñoz).............................99

Tabla 27. Ficha de la entrevista (Segmento D, Institución Pública) ...........................................100

Tabla 28. Observaciones de la entrevista (Segmento D, Abogado laboralista) ...........................101

Tabla 29. Ficha de la entrevista (Segmento D, Abogado laboralista).........................................102 


\section{Índice de figuras}

Figura 1. Demanda de Servicios de BPO - Centros de Contacto por Sector en Perú....................19

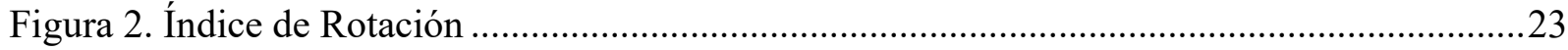




\section{CAPITULO I: INTRODUCCIÓN}

Con el avance tecnológico y el proceso de la globalización en las comunicaciones que se inició en la década de los años 90 en el Perú, el sector de Call Center ha experimentado un crecimiento, debido a la demanda de información de los clientes que utilizan el servicio. No solamente brinda sus servicios a través de una línea telefónica, que permite escuchar la voz del cliente, sino también a través de otros medios de comunicación como el chat, correo electrónico, videoconferencia, al igual que las redes sociales como el facebook, twitter, para mantenerlos informados y estar cada vez más cerca de ellos, dando como resultado la implementación de los Centros de Contacto, por esta razón, se ha generado un cambio en el proceso de sus gestiones, considerando los diferentes requerimientos de los clientes.

Los Centros de Contacto son más dinámicos en el mercado laboral, debido a las exigencias de las empresas que contratan este tipo de prestación de servicios. Para ello, deberán contar con una fuerza de trabajo altamente capacitada, con el fin de reducir la rotación de asesores telefónicos existentes.

De acuerdo con el objetivo general de esta investigación, ha sido necesario conocer los posibles factores que afectan la rotación de asesores telefónicos. Se tuvo dificultad en la obtención de material bibliográfico de tesis nacionales, problemática que persiste hasta la actualidad.

El Capítulo I, es un preámbulo en lo que se refiere a la definición de los Centros de Contacto, desde que se inició como Call Center y su actual funcionamiento; se menciona las definiciones básicas de ambos. Asimismo, los conceptos de algunos factores que podrían afectar la rotación de personal.

En el Capítulo II, se muestra la metodología cualitativa de tipo exploratorio y descriptivo, donde se midieron las variables de estudio de manera independiente, iniciándose con la metodología exploratoria, para obtener más información referente al tema. Luego, la descriptiva a través de la información obtenida por la investigación exploratoria. Se realizó un breve análisis con la finalidad de precisar la información recibida por cada entrevistado y, posteriormente realizar de manera conjunta un concepto por cada variable analizada. 
En el Capítulo III, según la información obtenida a través de las entrevistas de profundidad aplicadas a los diferentes segmentos durante el trabajo de campo, se presentaron algunos obstáculos: Encontrar asesores telefónicos con más de un año de permanencia, así como supervisores y gerentes con disponibilidad de tiempo, para ser entrevistados.

En el Capítulo IV, finalmente se procedió a consolidar la información y validar la hipótesis de investigación por cada variable. Los factores que afectan principalmente la rotación son: el turno de trabajo, las condiciones contractuales y la remuneración de los asesores telefónicos en los Centros de Contacto de Lima Metropolitana investigados. Además, se presentó las conclusiones y recomendaciones de la tesis. 


\subsection{Tema}

Factores que afectan la rotación de los asesores telefónicos en los Centros de Contacto de Lima Metropolitana.

\subsection{Situación problemática inicial}

A nivel mundial, el avance de las nuevas tecnologías de información y la globalización de las comunicaciones aumenta cada vez; por ello, "la competencia global ha provocado que las empresas busquen en forma constante reducir sus costos, de tal forma que cada una ha optado por desplazar algunas de sus actividades productivas o de prestación de servicios, hacia economías que les demanden menores costos; es decir, hacia países emergentes, quienes se ven beneficiados en términos de aumento de ingresos y generación de empleo" (Morris, y otros, 2009). De esta manera, el sector de los Centros de Contacto cuenta con mayor demanda de servicios a nivel internacional, lo que genera mayor cantidad de puestos de trabajo para atender las diferentes necesidades de los clientes.

A nivel latinoamericano, según Call Center News, en el año 2015 el mercado latinoamericano de Call Centers registró ingresos por \$240 millones y se espera que alcance los \$276 millones en el año 2021. Los países que experimentaron las mayores tasas de crecimiento de los últimos años han sido Perú, Chile y Colombia, informó la Oficina Comercial del Perú (Ocex) en Washington DC. (Gestión, 2017).

Los jóvenes tienen más oportunidades laborales, obtener experiencia en el rubro de atención al cliente y desarrollarse a través de líneas de carrera que ofrecen estas organizaciones.

Cada año, la industria de Centros de Contacto incluye a 4,500 peruanos en sus filas y para la mitad de estas contrataciones, estos puestos de trabajo son su primera experiencia laboral, afirmó la Asociación Peruana de Centros de Contacto Apecco. (El Comercio, 2014).

El crecimiento de la industria de los Centros de Contacto ayuda a la empleabilidad de más jóvenes peruanos, al mismo tiempo se incrementa la rotación del personal.

La rotación del personal afecta directamente el cumplimiento de las metas en las organizaciones y a la vez, se incrementan los costos operativos en la contratación de un nuevo personal. 
Como antecedentes del estudio, se consideró algunos trabajos de investigación como las similitudes de variables.

\section{Antecedentes nacionales}

Peña Arévalo, K. J. (2016). Las causas de rotación de personal incorporado por E-recruitment en el Grupo Telestant. Trujillo: Universidad César Vallejo.

Determinó que la rotación del personal se debe a los horarios de trabajo, con una media de 1.93 y a la falta de oportunidades de crecimiento con una media de 1.94 dentro de la organización. Esta medición fue realizada a través de una muestra de 60 ex trabajadores encuestados, quienes fueron contratados a través de E-recruitment (reclutamiento virtual).

Desposorio Jara, M. E. (2016). Los incentivos laborales y su influencia en la productividad de la empresa Call Center Tele Atento del Perú SAC, Plataforma BBVA Continental Trujillo.

Concluyó que los incentivos laborales influyen en la productividad, siendo lo más importante; los cuales se tienen que mejorar para incrementar la productividad en la empresa. El diseño utilizado en la investigación ha sido No experimental-Transaccional con una muestra de 58 asesores de servicios, lo que ha permitido describir variables y analizar su influencia e interrelación.

Guevara Campos, R.X.; Paxi Arocutipa, R.A \& Arratia Chucuya J.A (2016). Plan de mejora para disminuir la alta rotación de los tele operadores en la empresa Olva Contact Center de la ciudad de Tacna 2016: Instituto de Educación Superior Tecnológico Privado Jhon Von Neuman.

Aplicó un diseño no experimental, empírico, transversal, donde se utilizó una muestra de estudio de 60 encuestados aplicada a los tele operadores de Olva Contac Center, para poder visualizar los principales problemas acerca del factor que causa la alta deserción del personal en la organización, y así proponer un plan de mejora para la disminución de esta alta rotación. Se identificó la falta de oportunidades de ascenso, la insatisfacción por la remuneración recibida y sobre todo una de las principales causas: el estrés laboral. 


\section{$\underline{\text { Antecedentes Internacionales }}$}

Mondragón Chávarri, N. (2013). La motivación laboral extrínseca y su relación con el fenómeno de rotación de personal de los ejecutivos telefónicos del grupo Tele marketing Profesional Service. México.

Presentó un elevado índice en la motivación laboral extrínseca (reconocimiento y aspecto económico) y registra altos niveles de rotación de personal. En este aspecto, cabe considerar que la empresa en la que trabajan estas personas, no cubre sus expectativas motivacionales y por ello tienden a buscarlas en otra empresa; lo que determina una relación entre la motivación extrínseca y el fenómeno de rotación en este grupo de ejecutivos telefónicos.

Medellín Henao, M. F. (2013). Incidencia de la motivación en la rotación de personal de la empresa Digitex Internacional. Caldas, Colombia: Universidad Nacional de Colombia, Sede Manizales.

Concluyó que la actualización de puestos de trabajo, así como el reajuste en la estructura salarial, podrían facilitar una selección de personal más objetiva y coherente con el perfil del cargo, al igual que promover la participación activa de los trabajadores, contribuiría a aprovechar más su potencial y a que se sientan realmente útiles para la organización.

Arteaga, C. F. (Marzo de 2016). Propuesta para disminuir la rotación de personal en la sucursal American Call Center Quito - 2016. Quito, Ecuador: Universidad Central de Ecuador.

El autor concluye que existe un creciente número de empleados que renuncian a sus cargos, porque hay inconformidad con los sueldos, lo cual provoca la desmotivación paulatina y como consecuencia, buscan mejores oportunidades de trabajo. Se establecen dos estrategias para poder implementarlas y contribuir con la reducción del índice de rotación: compensación en la remuneración y perfeccionar los procesos de reclutamiento y selección de los empleados.

La mayoría de los Centros de Contacto están situados en Lima Metropolitana, según los datos recibidos por el especialista Edery Muñoz (Ver anexo 24). Por esta razón, se eligió desarrollar el trabajo de investigación en esta zona geográfica. Los factores tomados en cuenta para confirmar si afectan directamente con la rotación de asesores telefónicos en los centros de contacto son principalmente: el turno de trabajo, las condiciones contractuales y la remuneración promedio que éstos presentan. 


\subsection{Pregunta de investigación}

Para la elaboración de nuestro trabajo de investigación se formularon las siguientes preguntas, a fin de enfocar el tema de investigación.

\subsubsection{Pregunta Principal}

- ¿Cuáles son los factores que afectan la rotación de los asesores telefónicos en los Centros de Contacto de Lima Metropolitana?

\subsubsection{Preguntas Específicas}

- ¿Es el turno de trabajo un factor que afecta la rotación de los asesores telefónicos en los Centros de Contacto de Lima Metropolitana?

- ¿Son las condiciones contractuales los factores que afectan la rotación de los asesores telefónicos en los Centros de Contacto de Lima Metropolitana?

- ¿Es la remuneración un factor que afecta la rotación de los asesores telefónicos en los Centros de Contacto de Lima Metropolitana?

\subsection{Hipótesis inicial}

\subsubsection{Hipótesis General}

- Los factores que afectan principalmente la rotación de los asesores telefónicos en los Centros de Contacto de Lima Metropolitana son: el turno de trabajo, las condiciones contractuales y la remuneración.

\subsubsection{Hipótesis Específicas}

- El turno de trabajo es un factor que afecta principalmente la rotación de los asesores telefónicos en los Centros de Contacto de Lima Metropolitana.

- Las condiciones contractuales son factores que afectan principalmente la rotación de los asesores telefónicos en los Centros de Contacto de Lima Metropolitana.

- La remuneración es un factor que afecta principalmente la rotación de los asesores telefónicos en los Centros de Contacto de Lima Metropolitana. 


\subsection{Objetivo general}

- Identificar los factores que afectan principalmente la rotación de los asesores telefónicos en los Centros de Contacto de Lima Metropolitana.

\subsection{Objetivos específicos}

- Identificar cuáles son los turnos de trabajo y en qué medida afecta a los asesores telefónicos en los Centros de Contacto en Lima Metropolitana.

- Identificar cuáles son las condiciones contractuales establecidas frecuentemente en los Centros de Contacto de Lima Metropolitana.

- Identificar cuáles son los componentes de la remuneración establecidos frecuentemente en los centros de Contacto de Lima Metropolitana. 


\subsection{Marco Teórico}

\subsubsection{Definición de Call Center y Centros de Contacto}

Se detalla los conceptos para conocer las diferencias entre lo que era antes un Call Center y en lo que ahora se ha convertido, en un Centro de Contacto, porque cuenta con diversos canales de comunicación para estar más cerca de los clientes.

\subsubsection{Call Center}

"Un call center es el conjunto tecnológico y administrativo que permite unificar la inteligencia y potencia de procesamiento de los sistemas informáticos y las facilidades de la conmutación de llamadas telefónicas, para suministrar información a quienes llaman, en un ambiente de intimidad personal. De esta forma, el call center es el punto de contacto entre un cliente y la empresa por medio del hilo telefónico”. (Morris, y otros, 2009 Pág. 17)

\subsubsection{Contact Center o Centro de Contacto}

"Un Contact Center es el punto de contacto entre el cliente y la empresa a través de medios de comunicación como la vía telefónica, el correo electrónico, el chat y la comunicación multimedia por Internet. Es la evolución del call center, donde sólo existe un único punto de contacto: la línea telefónica.

“...aparecieron otros puntos de contacto entre el cliente y la empresa: el chat, el correo electrónico (e-mail) y el audio y videoconferencia por internet” (Morris, y otros, 2009, págs. 15)

\subsubsection{Principales Servicios del Centro de Contacto}

Según Morris, y otros (2009, págs. 18,20) se mencionan:

\section{$\underline{\text { Servicios inbound (servicios de entrada) }}$}

"Son aquellos en que el cliente se comunica con el contact center por llamada telefónica, sesión de chat o correo electrónico. Son catalogados como servicios de atención al cliente y por lo común absuelven consultas de información general con respecto a un producto o servicio. Desde un punto de vista funcional, el cliente realiza una llamada al contact center de la empresa, la que es atendida por un tele operador que, a su vez, atiende los requerimientos solicitados”. 
Servicios outbound (servicios de salida)

"Son aquellos en que el contact center se comunica con el cliente por llamada telefónica o correo electrónico. A través de los servicios outbound se realizan, por lo general, ventas, cobranzas, encuestas y se actualiza la base de datos de los clientes".

\subsubsection{Demanda de Servicios en los Centros de Contacto en el Perú}

Las empresas buscan tercerizar sus servicios cada vez más, a través de los Centros de Contacto, debido a la mayor demanda de información que requiere el cliente. Asimismo, el incremento de los niveles de ventas y la atención al cliente vía telefónica en los diferentes servicios que se ofrece.

De acuerdo con la información proporcionada en una entrevista realizada a uno de los especialistas en el sector de Centros de Contacto, David Edery Muñoz (Gerente de Exportación de Servicios en PROMPERÚ, (Ver anexo cuadro 24) se obtuvo la siguiente información:

Los principales servicios exportados están orientados a la atención, retención y adquisición de clientes $36 \%$, ventas (crosselling y upselling) 34\%, cobranzas $18 \%$, mesa de ayuda $2 \%$ y otros.

Los sectores atendidos representativos son: Telecomunicaciones $25 \%$, banca, servicios financieros y seguros 23\%, y retail 12\% (PROMPERÚ, 2015)

Figura 1. Demanda de Servicios de BPO - Centros de Contacto por Sector en Perú

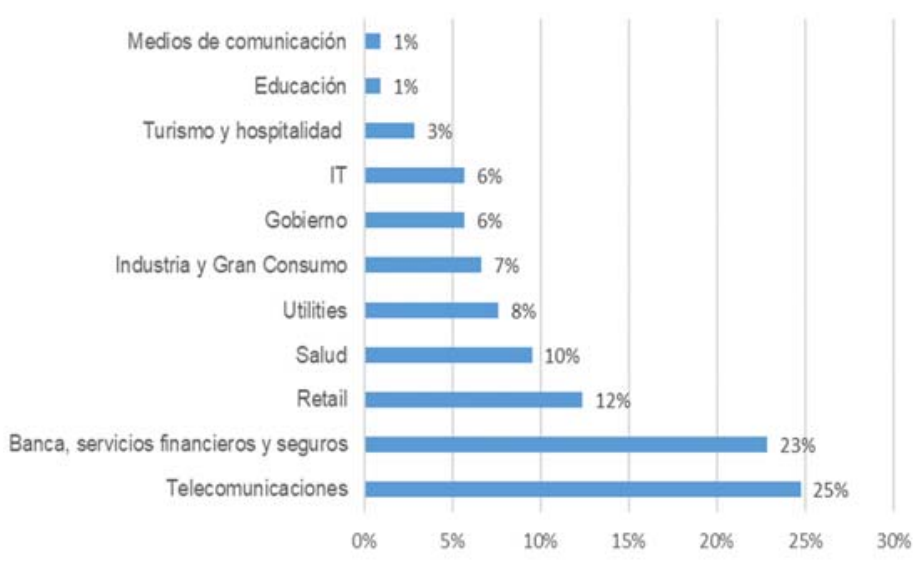

Fuente: (PROMPERÚ, 2015) 
En el Figura 1, se puede apreciar que el sector telecomunicaciones se concentra en un $25 \%$ del total de la demanda del servicio.

Según la información por parte del Departamento de Exportación de Servicios de PROMPERÚ (2016). Los Centros de Contacto ofrecen los siguientes servicios de exportación:

1. Gestión de Cobranza.- Recuperar carteras morosas.

2. Atención al Cliente.-Gestionar la relación con los clientes.

3. Venta y Tele marketing.-Contactar con clientes potenciales para ofrecer y vender productos y servicios.

4. Mesa de ayuda.-Proporcionar soporte técnico relacionado con un producto o servicio brindado.

5. Gestión de base de datos.- Actualizar, segmentar, depurar y analizar las bases de datos empresariales.

6. Fidelización.- Mantener y potenciar la relación entre el cliente y las empresas.

El especialista Edery Muñoz durante la entrevista nos indicó que son prioritarios: gestión de cobranzas, atención al cliente y ventas.

Medios de comunicación utilizados en los Centros de Contacto en el Perú

'En el sector de Centros de Contacto, el primer medio utilizado ha sido las llamadas telefónicas: la primera interacción entre un asesor telefónico y el cliente. Con el avance tecnológico aparecieron otros medios de comunicación como el correo electrónico, el chat, y videoconferencia. Pero a pesar del tiempo transcurrido, los clientes siguen manteniendo el contacto telefónico"; según la información proporcionada en una entrevista realizada al especialista en Centros de Contacto José Núñez Olivares Director de APECCO (Ver anexo cuadro 23).

"El canal de comunicación más utilizado sigue siendo el medio telefónico con un $92 \%$, no obstante, los centros de contacto también ofrecen otros medios de comunicación a través de los siguientes canales: chat 37\%, Twitter 16\%, Facebook 16\%, email 15\%" (APECCO, 2016).

\subsubsection{Definición de rotación de personal}

Según Chiavenato, en su libro Gestión del Talento Humano (2009) define la rotación de personal (o turnover) como: 
“...el resultado de la salida de algunos empleados y la entrada de otros para sustituirlos en el trabajo. Las organizaciones sufren un proceso continuo y dinámico de entropía negativa para mantener su integridad y sobrevivir. Esto significa que continuamente pierden energía y recursos y que se deben alimentar de más energías y recursos para garantizar su equilibrio. La rotación se refiere al flujo de entradas y salidas de personas en una organización; las entradas que compensan las salidas de las personas de las organizaciones. A cada separación casi siempre corresponde la contratación de un sustituto como reemplazo. Esto significa que el flujo de salidas (separaciones, despidos y jubilaciones) se debe compensar con un flujo equivalente de entradas (contrataciones) de personal. La separación se presenta cuando una persona deja de ser miembro de una organización”. (pág. 91)

Según Rodríguez en Introducción a la Psicología del Trabajo (1998) define rotación como:

"El derecho a buscar nuevas oportunidades y nuevos alicientes económicos y profesionales, para mejorar el status personal y profesional, es algo consustancial con la naturaleza humana y entraña múltiples aspectos positivos para el desarrollo de la carrera profesional del individuo". Asimismo, complementa esta definición como "el cambio que los empleados realizan de una organización a otra, con el objeto de desarrollar su carrera profesional mediante procesos de promoción o adquisición de nuevas experiencias que les permitirá enriquecer sus conocimientos, habilidades y potencial profesional, así como mejorar su nivel retributivo”. (págs. 247-248)

Por otro lado Cleveland (2008), "se refiere a si el empleado decidió abandonar la organización (voluntariamente) o la dirección tomó la decisión de terminar la relación contractual con él (involuntariamente) "Tipo de rotación” y puede dividirse en personas que dejaron la organización (externa) y empleados que dejan el puesto, pero asumen otro en la organización (interna).” (pág. 228)

También los autores, Milkovich \& Boudreau (1997) definen la rotación de personal, como:

"La decisión del personal de dejar o abandonar su puesto de trabajo y que se debe a factores internos de la organización, a factores relacionados con las características del individuo, y a factores del mercado de trabajo. 
Entre los factores de la organización, se mencionan: las políticas, prácticas y retribuciones de la organización, el contenido de trabajo, el clima laboral, los estilos de supervisión, las condiciones de trabajo y las relaciones interpersonales con los grupos de trabajo, entre otros.

Los factores personales están asociados a las características socio-demográficas de los trabajadores tales como la edad, educación y responsabilidad familiar, así como otras condiciones relacionadas con la posición que ocupa en su centro de trabajo (nivel jerárquico, nivel de habilidad, estatus y profesionalismo).

Entre los factores de mercado de trabajo, se consideran los niveles de desempleo, 0porcentaje de vacantes, publicidad y reclutamiento, así como la comunicación verbal” (pág. 304)

Por último, Dale (1983) menciona: "Los departamentos de personal pueden y deben, en general, contribuir con la disminución de la tasa de rotación de personal colaborando activamente en la labor de conseguir que los empleados logren sus objetivos, cuando esto ocurre se benefician tanto el empleado como la organización”. (pág. 581)

En los centros de contacto investigados en Lima Metropolitana la rotación de personal es frecuente, debido a las diferentes campañas de corto plazo que las empresas establecen al momento de contratar personal y luego finalizar el término del contrato.

\subsubsection{Tipos de rotación de personal}

Chiavenato (2009):

"Indica que existen dos tipos de separación: la separación por iniciativa del empleado (renuncia) y la separación por iniciativa de la organización (despido).

a) Separación por iniciativa del empleado (renuncia). Se presenta cuando un empleado decide, por razones personales o profesionales, terminar la relación de trabajo con el empleador. La decisión de separarse depende de dos percepciones. La primera es el nivel de insatisfacción del empleado con el trabajo. La segunda es el número de alternativas atractivas que éste encuentra fuera de la organización, en el mercado laboral. 
b) Separación por iniciativa de la organización (despido). Ocurre cuando la organización decide separar a los empleados, sea para sustituirlos por otros más adecuados en base a sus necesidades, para corregir problemas de selección inadecuada o para reducir su fuerza de trabajo. Los cambios en el diseño de los puestos provocan transferencias, recolocaciones, tareas compartidas, reducción de horas de trabajo y despido de colaboradores.

De ahí la necesidad de medir el nivel de separaciones de la organización. El índice de separación mide la proporción de éstas en relación con el tamaño de las fuerzas de trabajo. La fórmula más utilizada es el número de personas que se separan durante un periodo determinado (un mes o un año) en relación con el número promedio existente de empleados. Sin embargo, esta fórmula funciona en relación con las salidas, pero no considera las entradas de personal a la organización.

A continuación, se detalla la fórmula que se utiliza para calcular el índice de rotación:

Figura 2. Índice de Rotación

Índice de Rotación $=$ Número de empleados separados

Promedio efectivo de la organización

La rotación no es la causa, sino el efecto de algunas variables externas e internas. Entre las variables externas están la situación de la oferta y la demanda del mercado de recursos humanos, la coyuntura económica, las oportunidades de empleo en el mercado de trabajo, etcétera. Algunas variables internas responsables de la política salarial y de prestaciones que la organización ofrece son: el estilo administrativo, las oportunidades de crecimiento interno, el diseño de los puestos, las relaciones humanas, las condiciones físicas y psicológicas del trabajo, la estructura y la cultura organizacional.” (pág. 92).

En los centros de contacto investigados en Lima Metropolitana se presentan renuncias voluntarias por parte de los asesores telefónicos y por otro lado, la desvinculación por parte de la empresa al no renovar los contratos después del periodo de prueba o término de una campaña. 


\subsubsection{Factores}

Desde la gestión de la Administración de Recursos Humanos, se desprenden las siguientes variables de investigación.

\subsubsection{Jornada Laboral}

Según el autor (Chiavenato, 2009, págs. 519-523) “, describe la jornada laboral como:

La Jornada de trabajo representa el número de horas diarias, semanales o mensuales que el colaborador debe cumplir debido a su contrato individual de trabajo y para satisfacer el horario laboral convenido colectivamente.

La jornada prevé un horario fijo de entrada y de salida en los días laborables, con cierta tolerancia de retrasos y adelantos. También prevé un determinado intervalo para comidas y de descanso.

El calendario anual de trabajo, el cual establece los días laborables y los llamados puentes (días laborables que quedan entre días feriados y los sábados o domingos en que no se trabaja).

Las vacaciones colectivas son una manera de simplificar el calendario y de reducir los costes laborales. Como cada colaborador tiene derecho a 30 días de vacaciones al año, cada grupo de 12 trabajadores requerirá de un trabajo adicional para cubrir las ausencias por vacaciones y poder respetar el programa de trabajo.

Las organizaciones ofrecen opciones de programas flexibles de trabajo, sobre todo cuando los colaboradores tienen diferentes necesidades e intereses. Las tres razones que sostienen estos programas opcionales son:

La respuesta de la organización a las necesidades de sus colaboradores, el apoyo para mejorar la imagen de la organización y la adopción de programas de asistencia al trabajo y a la familia.

Las principales opciones de programa flexible son:

Semana laboral reducida: la jornada semanal de cinco jornadas de ocho horas se puede programar de modo que se cumpla en menos días. 
En el horario flexible el trabajo se desempeña sujeto a un programa ajustable de horas diarias que cada colaborador adapta a su elección. Se llama horario flexible, flex time u horario movible. Así, el trabajo se programa de modo que permite que el colaborador escoja una parte del esquema de su jornada diaria. El horario flexible permite a las personas tener una mayor autonomía y responsabilidad por su trabajo.

Con un trabajo compartido, dos o más personas comparten o desempeñan un mismo puesto en diferentes horarios de trabajo.

El trabajo a distancia se realiza en casa y el colaborador no se tiene que presentar en la organización. El trabajo en casa (home office) está ganando adeptos en el mundo entero.

El trabajo de tiempo parcial es regular. Engloba a los llamados trabajadores eventuales, a los de medio tiempo, a los temporales y a los independientes."

Según la información expuesta por el autor Chiavenato con relación al concepto de la jornada laboral y en base a la indagación obtenida de los Centros de Contacto investigados, contratan trabajadores eventuales y están sujetos a exigencias del cliente o de la empresa que solicita sus servicios, es decir, por temporadas o campañas. También en la mayoría cuentan con trabajadores a tiempo parcial, con la finalidad de disminuir sus costos operativos.

\section{$\underline{\text { Horario de Trabajo }}$}

Según el autor (Ackerman y otros, Pág. 415)

"El horario de trabajo es la determinación del momento de inicio y, por otro tanto, también del término. La doctrina entiende que las partes de la relación de trabajo son libres para estipular el horario. Más aún: entiende que se comprende en el poder de dirección del empleador el derecho de cambiar, dentro de ciertos límites, el horario de prestación de servicios.

Como regla, es la empresa la que fija unilateralmente el horario. No es habitual que esta condición sea objeto de determinación en norma integrante del reglamento interior. Más raro aún es la estipulación del horario por medio de negociación colectiva y de acuerdos con los trabajadores o con sus representantes. Sin embargo, si existe el acuerdo o la previsión del horario en el reglamento interior, su alteración requiere el acuerdo de voluntades de trabajadores y patrones.” 
En los centros de contacto investigados, las empresas establecen el horario de los asesores telefónicos y ellos aceptan las condiciones, los horarios son rotativos dependiendo de la campaña, pueden variar sus horarios cada mes, cada tres meses o cada seis meses. Los turnos establecidos son los siguientes:

- Turno mañana

- Turno tarde

- Turno noche

\subsubsection{Condiciones Contractuales}

Se refiere a las contrataciones laborales, en referencia con las condiciones y términos de cada contrato, para ser pactadas por el empleador con su cliente o personal, sin que tenga la posibilidad de que éstas sean negociadas o modificadas.

Según la Ley de Productividad y Competitividad Laboral (LPCL) D.S. Nº03-97-TR, publicado el 27 de marzo de 1997 se detalla que la duración del contrato de trabajo puede ser por:

$\underline{\text { Contrato de trabajo de duración indeterminada }}$

"El contrato de trabajo se presume celebrado por tiempo indeterminado salvo prueba en contrario. Puede celebrarse por tiempo determinado en los casos previstos por esta Ley". Artículo 16.

- Contrato Intermitente

- Contrato de Temporada.

$\underline{\text { Contrato de trabajo de duración determinada }}$

"El contrato de trabajo de duración determinada puede celebrarse cuando así lo exija la naturaleza temporal o accidental del servicio que se va a prestar o de la obra que se va a ejecutar. Deben constar por escrito y por triplicado, debiendo consignarse en forma expresa las causas objetivas determinantes de la contratación, su duración, así como las demás condiciones de la relación laboral.” (Artículo 18)

- El contrato por necesidades coyunturales del mercado. 
- El contrato ocasional

- El contrato de suplencia

- El contrato por obra determinada o para servicio específico.

- El contrato expresamente autorizado por norma especial

En referencia al tema de investigación de los Centros de Contacto, es necesario profundizar la siguiente modalidad de contrato.

\section{$\underline{\text { Contrato por obra determinada o para servicio específico }}$}

"La duración está sujeta a la conclusión de la obra o del servicio específico para el que fue contratado. En el caso de este tipo de contrato se permite celebrar las renovaciones que resulten necesarias, para la conclusión de la obra o servicio objeto de contratación.” (Artículo 23).

"En este tipo de contratos podrán celebrarse las renovaciones que resulten necesarias para la conclusión o terminación de la obra o servicio objeto de la contratación.” (Artículo 63º).

"Si el trabajador fuera contratado por un mismo empleador por dos temporadas consecutivas o tres alternas, tendrá derecho a ser contratado en las temporadas siguientes.” (Artículo 69).

"Para hacer efectivo el ejercicio del derecho conferido en el artículo anterior, el trabajador deberá presentarse en la empresa, explotación o establecimiento dentro de los quince (15) días anteriores al inicio de la temporada, vencidos los cuales caducará su derecho a solicitar su readmisión en el trabajo." (Artículo $70^{\circ}$ ).

"Se asimila también al régimen legal del contrato de temporada a los incrementos regulares y periódicos de nivel de la actividad normal de la empresa o explotación, producto de un aumento sustancial de la demanda durante una parte del año, en el caso de los establecimientos o explotaciones en los cuales la actividad es continua y permanente durante todo el año." (Artículo $\left.71^{\circ}\right)$

Período de prueba en contratos de duración determinada.

“En los contratos de duración determinada rige el período de prueba conforme a lo previsto en la presente Ley". (Artículo 25). 
"El período de prueba es de tres meses, a cuyo término el trabajador alcanza derecho a la protección contra el despido arbitrario. Las partes pueden pactar un término mayor en caso las labores requieran de un período de capacitación o adaptación o que por su naturaleza o grado de responsabilidad, tal prolongación pueda resultar justificada." (Artículo $10^{\circ}$ Reglamento: Arts. $16^{\circ}$ y $\left.17^{\circ}\right)$

Durante el trabajo de campo para esta investigación, se logró obtener información sobre los contratos que se establece en los Centros de Contacto. Se ha podido observar que el contrato también utilizado es el contrato a tiempo parcial, debido a los diferentes turnos de trabajo de medio tiempo. Por lo general, los centros de contacto son exportadores de servicios y cuentan con clientes en el extranjero, es decir, se manejan diferentes horarios y para ello, tendrán que considerar el turno y la remuneración para establecer el contrato.

\section{$\underline{\text { Los contratos de trabajo a tiempo parcial }}$}

"El trabajador se obliga a prestar servicios en una jornada de trabajo inferior a cuatro horas diarias o a veinticuatro horas semanales." (Ley General del Trabajo Art .30)

"El contrato de trabajo a tiempo parcial puede celebrarse por tiempo indeterminado sin limitación alguna o por tiempo determinado.

Este contrato es celebrado necesariamente por escrito y se registra ante la Autoridad Administrativa de Trabajo dentro de los treinta (30) días siguientes a su suscripción.” (Ley General del Trabajo Art. 31)

\section{Derechos de los trabajadores}

"Los trabajadores contratados a tiempo parcial, gozan de los derechos que la ley reconoce a los trabajadores contratados a tiempo completo, con excepción de aquellos derechos para cuya percepción se exija laborar un mínimo de cuatro horas diarias o de veinticuatro horas semanales.

Estos trabajadores tienen la condición de afiliados regulares en los sistemas de seguridad social, debiendo calcularse las aportaciones respectivas sobre la base de la remuneración efectiva. Los períodos de aportación se computarán exclusivamente por las horas trabajadas." (Ley General del Trabajo Art. 32) 
Se analizó el tema de las modalidades contractuales. Estos contratos de tiempo determinado son temporales, además, se dan en un período fijo establecido, se puede considerar que se presenta como un problema para el asesor telefónico, generando una sensación de inseguridad cada vez que se acerca el vencimiento del plazo de contrato y posible renovación.

Para los centros de contacto es más factible aplicar esta modalidad, es decir, no sería necesario alguna justificación o explicación por la no renovación del contrato al asesor telefónico.

La contratación de personal bajo alguna de estas modalidades requiere tener en cuenta los aspectos legales, así como el tema de la remuneración.

\subsubsection{Definiciones de la remuneración}

Louffat (2010, pág. 170) "Las remuneraciones y compensaciones son el proceso técnico de la administración del potencial humano que se encarga de retribuir el desempeño laboral de sus trabajadores con un pago en valores monetarios o de servicios/especies; estas últimas denominadas también como prestaciones, compensaciones."

Byars \& Rue (1996, pág. 340) "Es el conjunto de retribuciones extrínsecas recibidas a cambio del trabajo. La paga es la suma de dinero recibida a cambio del trabajo. Normalmente, la remuneración está compuesta por el sueldo o salario base, los incentivos o primas y las prestaciones que procedan."

Werther \& Davis (2000, pág. 331) “La compensación (sueldos, salarios, prestaciones, etcétera) es la gratificación que los empleados reciben a cambio de su labor. La administración de esta vital área a través del departamento de personal garantiza la satisfacción de los empleados; lo que a su vez ayuda a la organización a obtener, mantener y retener una fuerza de trabajo productivo. Sin compensación adecuada, es probable que los empleados abandonen la organización y sea necesario reclutar personal de manera inmediata, con las dificultades que éstas representan.”

Por otro lado, Chiavenato (2002, pág. 230) menciona "Nadie trabaja gratis". "Como socio de la organización, cada empleado se interesa en invertir trabajo, dedicación y esfuerzo personal, conocimientos y habilidades, si recibe la retribución adecuada. Asimismo, las organizaciones se 
interesan en invertir en compensación para su personal, si reciben contribuciones que estén al alcance de sus objetivos. De ahí se deriva el concepto de remuneración total del empleado, que tiene tres componentes: remuneración básica, incentivos salariales y beneficios."

\section{a) Los tres componentes de la remuneración}

\section{1) Remuneración básica}

Según Chiavenato (2002) "Es la remuneración básica o pago fijo que recibe el empleado de manera regular como salario o salario por hora”. (pág. 230)

Para los autores Byars \& Rue (1996, pág. 356). "El salario base es el elemento fundamental que tienen en cuenta la mayoría de los empleados, para formarse una idea sobre la equidad del sistema de retribuciones. Si los empleados no perciben que están siendo pagados equitativamente, pueden producirse varios efectos negativos (retrasos, ausentismo, rotación de trabajo, huelgas, etcétera.). Además, el sistema de salarios base refleja con frecuencia el tono o atmósfera de toda la organización. Si ese sistema se considera equitativo, lo mismo sucede con la organización y, naturalmente, a la inversa. Es muy importante que la organización desarrolle y mantenga un sistema sólido de salarios base, por su trascendencia para toda ella."

En relación con la composición de los salarios: “...los sueldos dependen de varios factores internos (organizacionales) que lo condicionan. La definición de los salarios es compleja e incluye decisiones múltiples, pues los factores internos y externos están interrelacionados y ejercen efectos diferenciados sobre los salarios. Los factores actúan independientemente o en conjunto armónico, para elevar o bajar los salarios. Las decisiones respecto de los salarios se toman teniendo en cuenta el conjunto de los factores internos y externos que constituye el compuesto salarial." Chiavenato (2002 pág. 234)

\section{1) Incentivos salariales}

"Son programas diseñados para recompensar a empleados de buen desempeño. Los incentivos se conceden en diversas formas; por ejemplo, bonos y participación en los resultados, a título de recompensa por alcanzarlos”. (Chiavenato, 2002, pág. 231) 


\section{2) Las prestaciones sociales y beneficios}

"Las prestaciones son retribuciones recibidas en relación con el empleo y con el cargo desempeñado en una organización” (Byars \& Rue, 1996, pág. 348).

"Los beneficios, casi siempre denominados remuneración indirecta, se conceden a través de varios programas (vacaciones, seguro de vida, transporte subsidiado, restaurante subsidiado, etcétera.)" (Chiavenato, 2002, pág. 231).

En los centros de contacto investigados, la mayoría brinda un sueldo mínimo establecido por ley, lo que diferencia de cada uno de ellos son los incentivos salariales, beneficios, las diferentes comisiones establecidas y lo atractivo que resulta para cada asesor telefónico.

\section{b) Políticas de remuneración}

Chiavenato (2002, pág. 255) define:

"Política salarial es el conjunto de decisiones organizacionales sobre asuntos relacionados con la remuneración y los beneficios concedidos a los empleados.

El objetivo principal de la remuneración es crear un sistema de recompensas equitativo para la organización y para los empleados. Para que sea eficaz, la política salarial debe atender simultáneamente siete criterios;

1. Adecuada: la compensación se debe distanciar de los estándares mínimos establecidos por el gobierno o por la convención de trabajo.

2. Equitativa: cada persona debe ser pagada proporcionalmente de acuerdo con su esfuerzo, habilidades y capacitación profesional.

3. Equilibrada: salario, beneficios y otras recompensas deben proporcionar un paquete total de recompensas razonables.

4. Eficacia en cuanto a costos: los salarios no pueden ser excesivos, sino en función de lo que la organización pueda ganar.

5. Segura: los salarios deben ser suficientes para ayudar a los empleados a sentirse seguros y a satisfacer sus necesidades básicas.

6. Incentivadora: los salarios deben motivar eficazmente el trabajo productivo. 
7. Aceptable para los empleados: las personas deben comprender el sistema de salario y sentir que representa un sistema razonable para ellos y para la organización."

Por otro lado, los autores Byars \& Rue (1996, pág. 341) Indican:

"Para desarrollar y aplicar un buen sistema de retribuciones, primero hay que definir ciertas políticas. Naturalmente, estas políticas son muy sensibles a los objetivos y el entorno de la organización. Han de abordar las cuestiones siguientes:

Cuáles son los niveles: mínimo y máximo de remuneración (teniendo en cuenta el valor del puesto para la organización, la capacidad de pago de ésta, las disposiciones legales, la influencia sindical y las presiones del mercado).

Cuáles son las relaciones generales entre los niveles de remuneración (entre la alta gerencia y los directivos de producción, los empleados de producción y los supervisores).

Cómo ha de distribuirse la suma total de remuneraciones (es decir, qué porción va a parar al salario base, a programas de incentivos y a prestaciones)".

En los centros de contacto investigados, cada empresa determina su política de remuneración, establece un monto mínimo como salario base, así como metas e indicadores que los asesores telefónicos deberán cumplir para que puedan comisionar de acuerdo con las campañas que cada centro de contacto establece. La empresa fija los montos mínimos y máximos de cada bonificación que debe percibir cada asesor telefónico. 


\section{CAPÍTULO II METODOLOGÍA DE LA INVESTIGACIÓN}

\subsection{Planteamiento de la investigación}

\subsubsection{Propósito de la investigación}

El propósito de la investigación es identificar si los factores laborales con respecto al turno de trabajo, condiciones contractuales y remuneración influyen principalmente en la rotación de asesores telefónicos en los centros de contacto de Lima Metropolitana.

La principal motivación de esta investigación se basa en la experiencia personal de una de las integrantes del grupo, en donde su primera experiencia laboral fue en un Centro de Contacto hace 12 años atrás, desde ese entonces se presentaba esta problemática de rotación en los asesores telefónicos.

\subsubsection{Tipo de investigación}

Se aplicó una investigación exploratoria-descriptiva. "Inicialmente exploratoria para examinar un tema poco estudiado" (Hernández Sampieri Pág. 91). Se cuenta con pocos estudios relacionados con la rotación en este sector de Centros de Contacto, por ello, a través de una investigación exploratoria, se logró obtener la mayor información referente al tema. Se utilizó las herramientas de investigación como las entrevistas de profundidad, con la finalidad de conocer las opiniones y posturas por cada entrevistado del segmento establecido.

Con la investigación descriptiva "se pretende medir o recoger información de manera independiente o conjunta, sobre los conceptos o las variables a las que se refiere; su objetivo no es indicar cómo se relacionan éstas" (Hernández Sampieri pág. 92). A través de la información obtenida por la investigación exploratoria, se realizó el análisis, con la finalidad de precisar la información por cada entrevistado, para luego realizar de manera conjunta un concepto por cada variable analizada. 


\subsubsection{Diseño de la investigación}

La investigación es de diseño cualitativo, porque recoge información sobre las variables de estudio a través de las entrevistas de profundidad.

Según Hernández Sampieri (pág.7) "Utiliza la recolección y análisis de los datos para afinar las preguntas de investigación o revelar nuevas interrogantes en el proceso de interpretación”.

\subsubsection{Preguntas de Investigación}

Para la elaboración de nuestro trabajo de investigación se formularon las siguientes preguntas, a fin de enfocar el tema de investigación.

\subsubsection{Pregunta Principal}

- ¿Cuáles son los factores que afectan la rotación de los asesores telefónicos en los Centros de Contacto de Lima Metropolitana?

El planteamiento de esta pregunta de investigación se definió con la finalidad de conocer el porqué de la constante rotación de asesores telefónicos; por ello, se incluyó en el cuestionario semi estructurado como pregunta principal a manera que cada entrevistado, según su experiencia mencione los posibles factores que puedan afectar esta rotación.

\subsubsection{Preguntas específicas}

- ¿Es el turno de trabajo un factor que afecta la rotación de los asesores telefónicos en los Centros de Contacto de Lima Metropolitana?

Se consideró esta pregunta de investigación, ya que, el horario en la mayoría de los centros de contacto suele ser rotativo; hay diferentes horarios que se establecen para atender los diferentes requerimientos del cliente, tanto en Lima como a nivel nacional, y clientes que se encuentran en el exterior.

Con las entrevistas obtenidas con este tipo de pregunta, los asesores telefónicos entrevistados indicaron como estaban establecidos sus turnos de trabajo, horarios de descanso y con qué frecuencia existía variación de turnos. 
- ¿Son las condiciones contractuales los factores que afectan la rotación de los asesores telefónicos en los Centros de Contacto de Lima Metropolitana?

Se consideró esta pregunta debido a que la estabilidad laboral es importante y la mayoría de asesores telefónicos no tienen conocimiento de qué tipo de contrato firman.

Con las entrevistas obtenidas con este tipo de pregunta, los asesores telefónicos entrevistados indicaron la frecuencia con la que firman sus contratos, tiempo de periodo de prueba y tiempo de capacitación que recibió en su centro de contacto.

- ¿Es la remuneración un factor que afecta la rotación de los asesores telefónicos en los Centros de Contacto de Lima Metropolitana?

Se consideró plantear esta pregunta debido a que una de las motivaciones principales para todo trabajador es saber cuánto va a recibir por toda su gestión realizada y si ello cumple con sus expectativas laborales.

Con las entrevistas obtenidas, se deseaba conocer como estaba conformado el sueldo fijo y/o variable, es decir, si contaban con algún tipo de condiciones para percibir bonos o comisiones. 


\subsection{Contexto}

\subsubsection{Descripción del contexto interno y externo}

El contexto de la investigación se basa en la aplicación de entrevistas personales a los cuatro segmentos: asesores telefónicos de los Centros de Contacto; asesores telefónicos de los Centros de Contacto administrados por entidades bancarias; supervisores, jefes o gerentes de Recursos Humanos y especialistas del sector de Centros de Contacto de Lima Metropolitana.

Se describe las observaciones durante la aplicación de las entrevistas, es decir, el antes, durante y después de finalizada la entrevista, a fin de tener en consideración los detalles y conclusiones más relevantes.

Con apoyo de nuestra asesora, se elaboraron cartas de presentación dirigidas a los centros de contacto, donde se solicitaron entrevistas, sin éxito, ya que, el sector resultó ser muy restringido y la información se obtuvo con dificultad.

La mayoría de las entrevistas concretadas se coordinaron a través de correos electrónicos. En el caso de algunos supervisores y gerentes, se llevaron a cabo en las instalaciones de los mismos centros de contacto.

Las entrevistas concretadas con los asesores telefónicos y especialistas se realizaron en horarios y lugares a solicitud del entrevistado. 


\subsection{Muestra}

\subsubsection{Descripción de la muestra}

Para obtener información detallada y relevante en el trabajo de investigación, se utilizó la herramienta flexible: las entrevistas a profundidad aplicable a cada segmento de investigación.

Según Roberto Hernández Sampieri, Carlos Fernández Collado, María del Pilar Baptista Lucio (pág. 403) indican lo siguiente: "La entrevista se define como una reunión para conversar e intercambiar información entre una persona (el entrevistador) y otra (el entrevistado) $\mathrm{u}$ otras (entrevistados)".

Los entrevistados pertenecen a cuatro segmentos diferentes y son los siguientes: los asesores telefónicos de los Centros de Contacto; asesores telefónicos de los Centros de Contacto administrados por entidades bancarias; supervisores, jefes o gerentes de Recursos Humanos y especialistas del sector de Centros de Contacto.

El tipo de muestra de cada segmento es no probabilística debido al tipo de investigación exploratorio-descriptivo aplicado en el trabajo de investigación.

Igualmente, los autores mencionados en su libro (pág.176) indican lo siguiente: "En las muestras no probabilísticas, la elección de los elementos no depende de la probabilidad, sino de causas relacionadas con las características de la investigación o los propósitos del investigador”.

Con el fin de responder las preguntas planteadas en este proyecto de investigación, se seleccionaron cuatro tipos de segmentos:

\section{Segmento A. Asesores telefónicos de Centros de Contacto}

El perfil de los asesores telefónicos: experiencia laboral mayor a cuatro meses en los servicios de llamadas inbound y outbound en las áreas de ventas, cobranzas y atención al cliente, con un rango de edad entre los 25 y 45 años, que trabajen actualmente en los Centros de Contacto de Lima Metropolitana. 
Herramienta: Entrevista de profundidad / Muestra: No Probabilística Aleatoria

Número de entrevistados: 4

\section{Segmento B. Asesores telefónicos de Centros de Contacto administrados por entidades bancarias.}

El perfil de los asesores telefónicos es: experiencia laboral mayor a un año en los servicios de llamadas inbound y outbound en las áreas de ventas, cobranzas y atención al cliente, con un rango de edad entre los 25 y 45 años, que trabajen actualmente en los Centros de Contacto administrados por entidades bancarias en Lima Metropolitana.

Herramienta: Entrevista de profundidad / Muestra: No Probabilística Número de entrevistados: 2

\section{Segmento C. Supervisores, jefes o gerentes de Recursos Humanos.}

El perfil de este segmento es para todos los supervisores, jefes y gerentes de Recursos Humanos que cuenten con experiencia de dos años a más en los Centros de Contacto y Centro de Contacto administrados por entidades bancarias en Lima Metropolitana, se escoge este segmento debido a que los supervisores trabajan directamente con los asesores telefónicos, tienen comunicación directa con ellos y pueden informar los motivos de renuncias o el motivo por el que dejan de trabajar en los Centros de Contacto. Ellos evalúan constantemente a los asesores telefónicos, los reportes de los supervisores van directamente a los jefes o gerentes de Recursos Humanos, son ellos los que conocen de cerca a qué se debe la constante rotación de asesores telefónicos en los Centros de Contacto de Lima Metropolitana.

Herramienta: Entrevista de profundidad / Muestra: No Probabilística Número de entrevistados: 5

\section{Segmento D. Especialistas del sector de servicios de Centros de Contacto.}

El perfil de este segmento está dirigido a los especialistas con más de diez años de experiencia en el sector de Centros de Contacto de Lima Metropolitana. La trayectoria de los especialistas favorece para obtener información relevante en el trabajo de investigación.

Herramienta: Entrevista de profundidad / Muestra de expertos: No Probabilística Número de entrevistados: 3 
Formación académica y experiencia de los especialistas

\author{
Presidente de APECCO (Institución Privada) \\ Empresa: APECCO \\ Cargo: Presidente \\ Fecha: De mayo 2008 a la actualidad \\ Empresa: HDC BPO SERVICE \\ Cargo: Director General \\ Inicio: De 2000 a la actualidad
}

\title{
Gerente de Exportación de Servicios (Institución Pública)
}

MBA Master Business Administration 2008 - 2010 - Universidad de Tarapacá

Diplomado, Gestión 2007 - 2007 - Universidad ESAN

Economista, 1984 - 1988 -Universidad Inca Garcilaso de la Vega

Empresa: PROMPERÚ

Cargo: Gerente de Exportación de Servicios

Fecha: De enero 2008 a la actualidad

Empresa: Universidad de Lima

Cargo: Profesor de Exportación e Importación de Servicios en Administración de Negocios

Fecha: De abril 2015 a la actualidad

Empresa: UPC - Programa EPE

Cargo: Profesor de exportación de Servicios EPE

Fecha: De abril 2012 a la actualidad

Empresa: Comisión de Promoción del Perú para la exportación y el Turismo

Cargo: Gerente de Programas y Proyectos Multisectoriales

Fecha: De enero 1998 a la actualidad

\section{Marcos (Abogado laboralista)}

Magister, Derecho del Trabajo 2009 - 2011 - Universidad San Martín de Porres

Abogado, Derecho del Trabajo 1997 - 2002 - Universidad San Martín de Porres

Empresa: Estudio Elías Mantero Abogados

Cargo: Abogado Asociado

Fecha: De enero 2018 a la actualidad

Empresa: ARS Management SAC

Cargo: Abogado

Fecha: De julio 2016 a la actualidad

Empresa: Quirós Horna \& Asociados

Cargo: Gerente de Asuntos Procesales

Fecha: De setiembre 2014 a la actualidad

Empresa: Consultor de Empresas Consultor Permanente

Cargo: Abogado - Apoderado

Fecha: De febrero 2012 a la actualidad

Empresa: Catedrático Instituciones Educativas Nivel Superior

Cargo: Catedrático

Fecha: De marzo 2009 a la actualidad 
Tabla 1. Detalle de la Muestra

\begin{tabular}{|c|c|c|c|}
\hline $\begin{array}{c}\text { Segmento A } \\
\text { Asesores telefónicos } \\
\text { de los Centros de } \\
\text { Contacto }\end{array}$ & \begin{tabular}{|c|} 
Segmento B \\
Asesores telefónicos \\
de los Centros de \\
Contacto \\
Administrado por \\
Entidades Bancarias.
\end{tabular} & $\begin{array}{c}\text { Segmento C } \\
\text { Supervisores, jefes } \\
\text { o gerentes de } \\
\text { Recursos } \\
\text { Humanos. }\end{array}$ & $\begin{array}{c}\text { Segmento D } \\
\text { Especialistas del } \\
\text { sector de servicios } \\
\text { de Centros de } \\
\text { Contacto. }\end{array}$ \\
\hline $\begin{array}{l}\text { Grupo objetivo de la } \\
\text { investigación. }\end{array}$ & $\begin{array}{l}\text { Grupo de asesores } \\
\text { telefónicos con similar } \\
\text { labor. }\end{array}$ & $\begin{array}{l}\text { Grupo que tiene por } \\
\text { objetivo contrastar la } \\
\text { información } \\
\text { obtenida por } \\
\text { segmentos A y B }\end{array}$ & $\begin{array}{lr}\text { Es necesaria la } \\
\text { opción r de } \\
\text { individuos expertos } \\
\text { en un tema. } \\
\text { (Sampieri rág. } \\
\text { 397). }\end{array}$ \\
\hline $\begin{array}{l}\text { Inicialmente se } \\
\text { planteó concretar } \\
\text { entrevistas con un } \\
\text { asesor telefónico por } \\
\text { cada Centro de } \\
\text { Contacto de Lima } \\
\text { Metropolitana. } \\
\text { En la investigación } \\
\text { en campo se concretó } \\
4 \text { entrevistas en los } \\
\text { Centros de Contacto } \\
\text { que tuvimos mayor } \\
\text { información }\end{array}$ & $\begin{array}{l}\text { Inicialmente se planteó } \\
\text { concretar entrevistas } \\
\text { con un } \\
\text { telefónico por } \\
\text { Centro de }\end{array}$ & 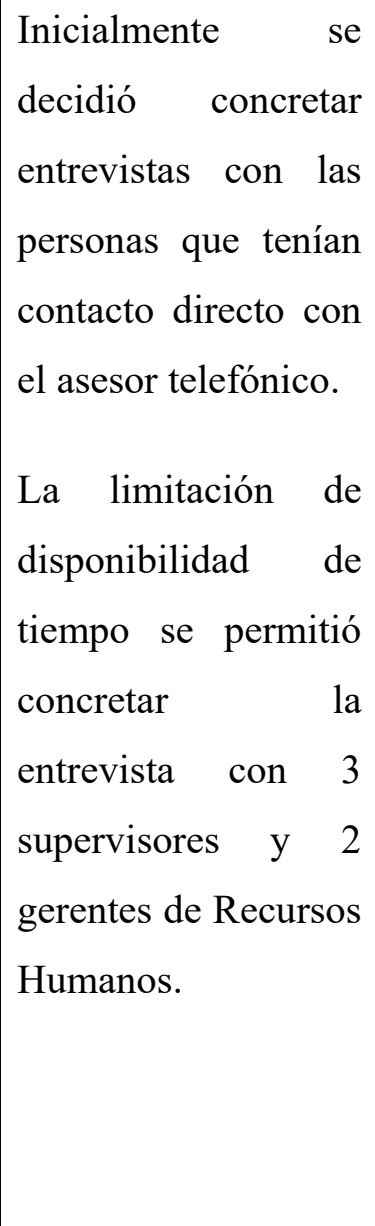 & $\begin{array}{l}\text { Se consideró que } \\
\text { era necesario tomar } \\
3 \text { entrevistas con: } \\
\text { - Representante de } \\
\text { una entidad } \\
\text { Privada. } \\
\text { - Representante de } \\
\text { una entidad Pública } \\
\text { - Abogado } \\
\text { laboralista, Con la } \\
\text { finalidad de } \\
\text { profundizar los } \\
\text { temas acerca de las } \\
\text { condiciones y } \\
\text { normativas sobre } \\
\text { contratos. }\end{array}$ \\
\hline
\end{tabular}




\subsection{Diseño o abordaje principal}

El diseño de investigación se basa en una Teoría Fundamentada, porque se busca que a través de la aplicación de entrevistas de profundidad, se pueda responder al principal problema de la investigación realizada.

Strauss \& Corbin (1990) “Afirman que la Teoría Fundamentada puede ser utilizada para un mejor entendimiento de un fenómeno ya estudiado y así poder profundizar en él”.

\subsubsection{Identificación de la estructura de la entrevista de profundidad.}

Se cree conveniente utilizar la herramienta de entrevista de profundidad.

Se elaboró un cuadro filtro por cada segmento a investigar, conforme se aplicaron las entrevistas se fue adecuando la guía de preguntas.

Con la entrevista de profundidad se permitió que el entrevistado pueda hablar con libertad sobre el tema de investigación y así se logró obtener más información y realizar un análisis sobre lo estudiado.

No se utilizó la herramienta de focus group, debido a horarios y fechas específicas para su desarrollo.

\subsubsection{Guía de preguntas}

Se estableció realizar una guía de la confección de un cuestionario semi estructurado, con preguntas abiertas y bajo la elaboración de una guía de preguntas, con el fin de obtener la información más completa para dar respuesta al problema de investigación, el cual fue modificado de acuerdo con el segmento a investigar.

(Ver Anexos 05, 06 y 07)

\subsubsection{Segmentos}

Se seleccionó los siguientes segmentos: 
Tabla 2. Descripción de Segmentos

\begin{tabular}{|c|l|}
\hline Segmentos & \multicolumn{1}{|c|}{ Descripción } \\
\hline $\begin{array}{c}\text { Segmento A } \\
\begin{array}{c}\text { Asesores telefónicos en } \\
\text { los Centros de Contacto. }\end{array}\end{array}$ & $\begin{array}{l}\text { Asesores telefónicos desde los } 18 \text { a } 45 \text { años, con o sin } \\
\text { y ventas, mayor a 4 meses de permanencia. }\end{array}$ \\
\hline $\begin{array}{c}\text { Segmento B } \\
\text { Asesores telefónicos en } \\
\text { los Centros de Contacto } \\
\text { Administrados por } \\
\text { Entidades Bancarias. }\end{array}$ & $\begin{array}{l}\text { Asesores telefónicos desde los 18 a 45 años, con experiencia } \\
\text { laboral en el área de atención al cliente, cobranzas y ventas, } \\
\text { mayor a un año de permanencia. }\end{array}$ \\
\hline $\begin{array}{c}\text { Segmento C } \\
\text { Supervisores, jefe o } \\
\text { gerente de Recursos } \\
\text { Humanos de Centros de } \\
\text { Contacto }\end{array}$ & $\begin{array}{l}\text { Supervisores a cargo de un equipo o grupo de asesores } \\
\text { telefónicos y jefes o gerentes a cargo del área de Recursos } \\
\text { Humanos con más de 2 años de permanencia. }\end{array}$ \\
\hline $\begin{array}{c}\text { Segmento D } \\
\text { Especialista del sector } \\
\text { de Centros de Contacto }\end{array}$ & Perfil 2. Institución Pública con más de 10 años en el sector. \\
\cline { 2 - 3 } & $\begin{array}{l}\text { Perfil 3. Profesional conocedor de normas y modalidades } \\
\text { contractuales con más de 10 años de experiencia. }\end{array}$ \\
\hline & \\
\hline
\end{tabular}

\subsubsection{Categorías}

Se tomó en cuenta las preguntas semi estructuradas. "El entrevistador solicita al entrevistado una lista de conceptos a manera de conjunto o categorías" (Sampieri Pág. 420). Se establecieron las siguientes categorías relacionadas con la herramienta de entrevista de profundidad.

\section{$\underline{\text { Segmentos A y B }}$}

En ambos segmentos se inició con preguntas generales, preguntas complejas, preguntas sensibles y preguntas de cierre, tal como se muestra a continuación:

Experiencia en el sector de Centros de Contacto: Se empieza con preguntas acerca de la identificación y experiencia que tiene el entrevistado con respecto al sector de Centros de Contacto. 
Información de las variables de estudio: Luego, preguntas acerca de las variables de investigación sobre los turnos de trabajo, condiciones contractuales y el sistema de remuneración que perciben en los Centro de Contacto.

Factores que afectan la rotación de asesores telefónicos: En esta parte, se busca conocer la percepción que tiene el entrevistado sobre la rotación de los asesores telefónicos en los Centros de Contacto de Lima Metropolitana.

Información Adicional: En esta categoría, se toma en cuenta la apreciación que ha tenido el entrevistado con respecto a un punto que no se ha tocado en la entrevista.

\section{$\underline{\text { Segmentos C y D }}$}

En ambos segmentos se inició con preguntas generales, preguntas complejas, preguntas sensibles y preguntas de cierre, tal como se muestra a continuación:

Experiencia en el sector de Centros de Contacto: Se inicia con preguntas acerca de la identificación y experiencia que tiene el entrevistado con respecto al sector, además, brindaron información sobre el perfil de un asesor telefónico en su Centro de Contacto.

Información de las variables de estudio: Se realizó preguntas acerca de las variables de investigación sobre las políticas establecidas con respecto a turnos de trabajo, modalidades contractuales y el sistema de remuneración que percibe el asesor telefónico en su Centro de Contacto.

Factores que afectan la rotación de asesores telefónicos: En esta parte, se buscó conocer la percepción que tiene el entrevistado sobre la rotación de los asesores telefónicos en su Centro de Contacto.

Información Adicional: En esta categoría, se toma en cuenta la apreciación que ha tenido el entrevistado con respecto a un punto que no se ha tocado en la entrevista. 


\subsubsection{El Instrumento de investigación}

Debido a que la investigación es cualitativa se empleó la entrevista de profundidad como herramienta para recolectar datos. Así mismo se elaboró un cuestionario semi estructurado, con la finalidad de levantar la mayor información posible del tema de investigación.

El cuestionario semi estructurado cuenta con el contenido de preguntas establecidas para cada segmento. Para el segmento A y B (Ver anexo 5). Finalmente, para el segmento C y D (Ver anexo $6)$. 


\subsubsection{Cronograma}

Tabla 3. Detalle de actividades

\begin{tabular}{|c|c|c|c|c|c|c|c|c|c|c|c|c|c|c|c|c|c|c|c|c|}
\hline \multirow{2}{*}{ ACTIVIDADES } & \multicolumn{4}{|c|}{ JULIO } & \multicolumn{4}{|c|}{ AGOSTO } & \multicolumn{4}{|c|}{ SETIEMBRE } & \multicolumn{4}{|c|}{ NOVIEMBRE } & \multicolumn{4}{|c|}{ DICIEMBRE } \\
\hline & 1 & 2 & 3 & 4 & 1 & 2 & 3 & 4 & 1 & 2 & 4 & 5 & 1 & 2 & 3 & 4 & 1 & 2 & 3 & 4 \\
\hline Elección de tema de Tesis & $\mathbf{x}$ & & & & & & & & & & & & & & & & & & & \\
\hline Revisión de la problemática & $\mathbf{x}$ & & & & & & & & & & & & & & & & & & & \\
\hline Búsqueda de referencias bibliográficas & $\mathbf{x}$ & & & & & & & & & & & & & & & & & & & \\
\hline Elaboración del Anteproyecto de tesis & & $\mathbf{x}$ & $\mathbf{x}$ & $\mathbf{x}$ & & & & & & & & & & & & & & & & \\
\hline Aprobación del Anteproyecto de tesis & & & & & $\mathbf{x}$ & $\mathbf{x}$ & $\mathbf{x}$ & & & & & & & & & & & & & \\
\hline Revisión del marco teórico Capítulo I & & & & & & & $\mathbf{x}$ & $\mathbf{x}$ & & & & & & & & & & & & \\
\hline Elección de tipo de metodología & & & & & & & & & $\mathbf{x}$ & & & & & & & & & & & \\
\hline Corrección de las observaciones & & & & & & & & & $\mathbf{x}$ & $\mathbf{x}$ & & & & & & & & & & \\
\hline Elaboración del Capítulo II & & & & & & & & & $\mathbf{x}$ & $\mathbf{x}$ & & & & & & & & & & \\
\hline Elección del segmento a investigar & & & & & & & & & & $\mathbf{x}$ & & & & & & & & & & \\
\hline Elección de instrumentos y herramientas a utilizar & & & & & & & & & & $\mathbf{x}$ & & & & & & & & & & \\
\hline Selección de la muestra & & & & & & & & & & $\mathbf{x}$ & & & & & & & & & & \\
\hline Elaboración de la guía de pautas de entrevista & & & & & & & & & & $\mathbf{x}$ & & & & & & & & & & \\
\hline Elaboración de cuestionario & & & & & & & & & & & $\mathbf{x}$ & & & & & & & & & \\
\hline Investigación de Campo & & & & & & & & & & & & $\mathbf{x}$ & $\mathbf{x}$ & $\mathbf{x}$ & $\mathbf{x}$ & $\mathbf{x}$ & $\mathbf{x}$ & $\mathbf{x}$ & $\mathbf{x}$ & \\
\hline Aplicación de entrevistas a especialistas & & & & & & & & & & & & & $\mathbf{x}$ & $\mathbf{x}$ & & & & & & \\
\hline Aplicación de las entrevistas a encargados de RRHH & & & & & & & & & & & & & $\mathbf{x}$ & $\mathbf{x}$ & & & & & & \\
\hline Aplicación de encuestas a los asesores telefónicos & & & & & & & & & & & & & & & $\mathbf{x}$ & $\mathbf{x}$ & $\mathbf{x}$ & $\mathbf{x}$ & $\mathbf{x}$ & \\
\hline $\begin{array}{l}\text { Aplicación de encuestas a los asesores telefónicos de los } \\
\text { Centros de Contacto administrados por entidades bancarias }\end{array}$ & & & & & & & & & & & & & & & & & & $\mathbf{x}$ & $\mathbf{x}$ & \\
\hline Levantamiento de información & & & & & & & & & & & & & & & & & & & & $\mathbf{x}$ \\
\hline Análisis de los resultados Capítulo III & & & & & & & & & & & & & & & & & & & & $\mathbf{x}$ \\
\hline Análisis de las variables & & & & & & & & & & & & & & & & & & & & $\mathbf{x}$ \\
\hline Elaboración Capítulo IV & & & & & & & & & & & & & & & & & & & & $\mathbf{x}$ \\
\hline Conclusiones y recomendaciones & & & & & & & & & & & & & & & & & & & & $\mathbf{x}$ \\
\hline
\end{tabular}




\section{Fuente: Elaboración propia.}

Las fechas programadas en el cronograma fueron establecidas en base a los tiempos del taller recibido por parte de la universidad. Se logró cumplir con los tiempos indicados para la elección de metodología, segmentación y herramientas de investigación.

Finalmente, el análisis de los resultados de las entrevistas fue presentado posteriormente a la culminación del cronograma inicial, por temas de tiempo y coordinación. 


\section{CAPÍTULO III ANÁLISIS DE DATOS Y RESULTADOS}

\subsection{Procedimiento: procesamiento de la información}

Se basó en una investigación cualitativa-descriptiva de la siguiente manera:

$\underline{\text { Primero, }}$, se aplicó la serie de entrevistas de profundidad a los grupos objeto de investigación. Se comenzó por entrevistar al grupo de los asesores telefónicos de los Centros de Contacto, los asesores telefónicos de los Centros de Contacto administrado por entidades bancarias; luego los supervisores, gerentes del área de Recursos Humanos y finalmente al grupo de expertos, según el perfil definido en la muestra.

$\underline{\text { Segundo, }}$, se recolectó la información del segmento A y luego se contrastó con las entrevistas del segmento B, a fin de comparar las variables de estudios, en cuanto a los turnos de trabajo establecidos, condiciones contractuales, así como la remuneración percibida por el cumplimiento de su labor.

$\underline{\text { Tercero, }}$, se elaboró un cuadro resumen de la información compilada de los principales hallazgos por cada entrevista de profundidad, a fin de contar con la información en conjunto y así poder compararlo con todos los segmentos. (Ver anexo 3)

Se extrapoló los puntos encontrados en común en la bitácora del contexto interno y externo de las entrevistas de profundidad por cada segmento. (Ver anexo 4) 


\subsection{Discusión de resultados}

\section{Discusión del Segmento A}

\section{Asesores telefónicos de Centros de Contacto de Lima Metropolitana investigados.}

Para este segmento se aplicaron cuatro entrevistas de profundidad en un periodo de tres meses. Los resultados en su mayoría similares. Se consideró entrevistar al asesor telefónico en un ambiente externo y en los horarios sugeridos por ellos mismos.

Para todos los entrevistados los horarios son establecidos de acuerdo con las diferentes campañas que cada Centro de Contacto establece y firman contrato de renovación cada 3 meses.

María (Ver tabla 9) indica que los cambios de horarios son informados previamente. Para Maritza y María (Ver tabla 5 y 9), las horas efectivas laboradas son de 6 horas diarias, indicando que el tiempo que se dedican a negociar su venta, les permite tener actividades paralelas, es decir, se encuentran conforme con sus horarios, a menos cantidad de horas laborales se reduce el estrés producido por la gestión realizada. Ambas, indican que la capacitación es demasiado corta, lo que no permite que los asesores se encuentren debidamente preparados al momento de ejercer sus funciones.

Todos los entrevistados no están de acuerdo que el sueldo base sea $\mathrm{S} / 850.00$, puesto que, en caso no cumplan con las escalas o indicadores de venta o cobranzas por alguna razón, solo recibirán el sueldo mínimo, el cual refieren que este monto es bajo y en algunos casos solo logra cubrir sus necesidades básicas.

Finalmente, la variable de comisión oscila entre S/ 300.00 a S/ 1000.00 en promedio, que dependerá de la campaña, logro de indicadores, objetivos individuales o grupales de ser el caso. 


\section{Discusión del Segmento B}

\section{Asesores telefónicos de Centros de Contacto Administrado por entidades bancarias de Lima Metropolitana investigados.}

Para este segmento se aplicaron dos entrevistas de profundidad en un periodo de tres meses. Los resultados en su mayoría fueron similares. Para este segmento también se consideró entrevistar al asesor telefónico en ambiente externo y en los horarios sugeridos por ellos mismos.

A diferencia del segmento A, el índice de rotación es menor.

Frank (Ver tabla 13) y Naya (Ver tabla 15) consideran que los beneficios y el respaldo que brinda cada entidad bancaria, es muy importante, la diferencia se encuentra en la política de contratación, además de enfatizar los requisitos del perfil del asesor telefónico, es decir con estudios superiores en curso o técnicos completos y experiencia previa en atención al cliente de forma presencial o por teléfono y no contar con antecedentes crediticios negativos.

Frank, precisa que los horarios son fijos de lunes a viernes, es opcional laborar el sábado, de acuerdo con la productividad, en el caso de la remuneración, menciona que el sueldo base debería ser mayor al mínimo vital, porque en caso de no alcanzar con sus indicadores mensuales, se verán tan afectado.

Para ambos entrevistados el tiempo de contratación es cada 6 meses y a partir del segundo año, se evalúa sus resultados para la realización de una contratación indeterminada.

Para Naya, hace referencia la línea de carrera que está establecida en cada área del Centro de Contacto, la cual considera que es necesaria para mejorar la estabilidad laboral.

Finalmente, la variable de comisión oscila entre S/ 1500.00 a S/ 2000.00 mensuales en promedio, que dependerá de la productividad, logro de indicadores y plazos de metas trimestrales.

A comparación del segmento A, la precisión y exigencia es mucho mayor, es por ello, que los montos de la variable son elevados, incluso, el nivel profesional dependerá que el asesor se encuentre con mayor competitividad y su permanencia sea la óptima en el Centro de Contacto. 


\section{Discusión del segmento C}

\section{Supervisores, jefes o gerentes de Recursos Humanos.}

Para este segmento se aplicaron cinco entrevistas de profundidad en un lapso de tres meses. Los resultados fueron variados, ya que se aplicaron entrevistas a supervisores, jefes o gerentes de Recursos Humanos de los Centro de Contacto del segmento A y B. Para este segmento los entrevistados agendaron citas según sus horarios disponibles y en sus respectivas instalaciones y/o oficinas de cada Centro de Contacto.

Con respecto al perfil del asesor telefónico no es igual en ambos segmentos. En el caso del perfil del asesor telefónico del segmento A depende del requerimiento de la empresa usuaria, contratando a personas con o sin experiencia laboral, con o sin estudios previos. El índice de rotación en este tipo de segmento es muy elevado. Según la gerente de Recursos Humanos de la empresa HDC Service (Ver tabla 21), indica que el puesto de asesor telefónico son posiciones golondrinas porque trabajan de manera temporal para cubrir necesidades básicas, se intenta hacer una línea de carrera y en el camino son pocos los que llegan a supervisores.

En segmento B, el perfil del asesor telefónico que contrata este segmento cuenta con mayores exigencias, con experiencia laboral o la mínima requerida dependiendo el área a ocupar. Según el supervisor del BCP (Ver tabla 19), indica que los asesores telefónicos si tienen una línea de carrera y el tiempo de permanencia es mayor a 4 años, la mayoría de asesores telefónicos son profesionales bachilleres o titulados

Los supervisores son el contacto directo con los asesores telefónicos, ellos conocen de cerca las necesidades y también los motivos de renuncias, ya sean voluntarias o involuntarias. Según la supervisora de Banco Interbank (Ver tabla 17), su personal tiene un periodo mayor a 2 años de permanencia, lo que ayuda a disminuir la rotación en su área. Brindarles un buen clima laboral y buenas condiciones de trabajo a veces no es suficiente porque los asesores telefónicos quieren ganar más y tener una línea de carrera, y en un Centro de Contacto es limitado. Según la Gerente de Recursos Humanos de la empresa MTG Perú (Ver tabla 23), indica que la remuneración puede ser baja, pero si el ambiente o clima laboral es muy bueno, el asesor permanecerá. Si la remuneración 
es baja y el clima no es bueno, el asesor abandona el trabajo y busca nuevas oportunidades. Muchas empresas no tienen una estructura de línea de carrera definida, permitiendo la fuga de talentos.

\section{Discusión del segmento D}

\section{Especialistas del sector de Centros de Contacto de Lima Metropolitana}

En este segmento se aplicaron tres entrevistas de profundidad en un periodo de tres meses. Para este segmento los entrevistados agendaron citas según sus horarios disponibles y en sus respectivas oficinas.

Desde el año 2002 en el Perú empezaron a posicionarse diferentes Centros de Contacto en la ciudad de Lima y en provincias, a medida que ha pasado el tiempo, ahora no solamente los call center son un centro de llamadas telefónicas de entradas y salidas, sino son llamados Centros de Contacto, porque también utilizan la comunicación vía mensajes de texto, correos electrónicos, facilitando las operaciones que los clientes requieren. Según el especialista de la Institución Pública (PromPerú) (Ver tabla 27), indica que la tasa de crecimiento se ha desacelerado porque ya no aparecen nuevos centros de contactos, debido a que cuentan con problemas de infraestructura, lo que genera malas condiciones laborales y esto podría ser un factor que genere la rotación. El índice de rotación en este sector ha sido de $18 \%$ en el primer trimestre del año 2017 , índice muy elevado porque debería estar entre un $10 \%$ o $11 \%$ anual.

Según el especialista de la Institución Privada (Ver tabla 25), indica que la rotación en este sector se da en jóvenes que oscilan entre 18 y 25 años, la mayoría sin experiencia laboral y sin estudios concluidos, teniendo un horario rotativo que no les permite una estabilidad para seguir estudiando o realizar actividades paralelas. Refiere que el sector tiene potencial de crecimiento para captar más jóvenes sin experiencia y generar mayor empleabilidad laboral. Según el abogado laboralista (Ver tabla 29), indica que por el desconocimiento que tienen los jóvenes en cuanto a su modalidad contractual, su periodo de prueba no supera los tres meses, lo que implica que la empresa llegue a desvincularlos antes del periodo de prueba. La remuneración mínima vital en el Perú es baja y el sueldo promedio no está acorde con la del mercado. Los horarios van de acuerdo con el contrato 
que tengan con el cliente usuario, los asesores telefónicos tienen que adaptarse a los diferentes turnos que cada centro de contacto establece en su contrato. 


\section{CAPÍTULO IV HALLAZGOS, CONCLUSIONES Y RECOMENDACIONES}

\subsection{Hallazgos}

- En relación con el factor de los turnos de trabajo, los horarios son establecidos de acuerdo con las campañas que tienen los Centros de Contacto investigados y en la mayoría los horarios son rotativos. Los asesores telefónicos tienen que adaptarse a los horarios, pueden trabajar en diferentes turnos, de mañana, tarde o noche. La edad promedio de la mayoría de los jóvenes oscila entre 18 y 22 años, quienes recién se insertan al mundo laboral, obteniendo su primer trabajo en un Centro de Contacto. Muchos de estos jóvenes no se adaptan a este tipo de trabajo y renuncian en menos de seis meses, incluso algunos no superan ni el periodo de prueba, no llegan a los tres meses, consideran el trabajo de manera temporal para que puedan cubrir algunas necesidades del momento.

- Los asesores telefónicos que se encuentran en un rango de edad entre 25 y 45 años presentan una mayor estabilidad laboral, tienen responsabilidades personales, lo que les permite permanecer mayor tiempo en un centro de contacto.

- En relación con el factor de las condiciones contractuales en los Centros de Contacto investigados en el segmento A, el tiempo de duración del contrato es determinado y se renueva cada tres meses. Si el asesor telefónico es menos productivo, su renovación de contrato puede reducirse a una renovación mensual o al despido por falta de cumplimiento de las metas establecidas. En el caso de los Centros de Contacto del segmento B, la renovación se da cada seis meses y la renovación está sujeta a una evaluación de resultados. Después de dos años se puede evaluar para un contrato indeterminado.

- En relación al factor de la remuneración, en los centros de contactos investigados, establecen el sueldo base o el sueldo mínimo que corresponde por ley y el sueldo variable que está 
conformado por las comisiones y beneficios adicionales según las políticas de remuneración en cada Centro de Contacto. Los asesores telefónicos entrevistados no están conformes con la remuneración mínima establecida como sueldo base, ya que consideran que es muy bajo en el mercado laboral; pero lo que sí les motiva es el sueldo variable percibido a cambio de su productividad. Algunos de los asesores telefónicos prefieren trabajar en centros de contacto donde las comisiones son más altas, que les permita mejorar sus ingresos y otras opciones de crecimiento laboral.

- Los asesores telefónicos entrevistados que pertenecen al segmento B, tienen otro tipo de perfil, las exigencias para la contratación de personal son mayores y los beneficios que brindan estos Centro de Contacto administrados por entidades bancarias son mejores en comparación al segmento A, debido a que ofrecen un mayor sueldo base, los horarios son fijos y las condiciones contractuales son más estables, lo que le brinda mayor estabilidad al asesor telefónico.

- Las líneas de carrera es un factor que causa la retención de asesores telefónicos de los Centros de Contacto de entidades bancarias, en comparación al Segmento A, que no cuenta con líneas de carreras establecidas.

- Otros factores encontrados son la edad, mientras más jóvenes, sin experiencia o estudios, sin habilidades blandas, sin carga familiar, es el riesgo que la adaptación a este tipo de labor sea prolongada. También, las condiciones laborales, es decir, el clima laboral, ambiente laboral son factores a considerar en la decisión de renuncia.

\subsection{Barreras}

- Algunos asesores telefónicos entrevistados se intimidaron por la filmación de las entrevistas.

- Uno de los jefes entrevistados de los Centros de Contacto se limitó a brindar datos, debido a que se negaba a la entrevista filmada.

- Inicialmente no se contaba con una correcta guía de preguntas, esto fue mejorando según las pautas de la asesora. 
- Poca disponibilidad de las principales empresas de los Centros de Contacto para facilitarnos entrevistas de acuerdo a los segmentos establecidos, a pesar de entregar cartas de presentación de manera presencial emitidas por parte de la universidad.

\subsection{Brechas}

- Para concretar una entrevista en un Centro de Contacto administrado por entidades bancarias, la jefa del área de Recursos Humanos solicitó el cuestionario de preguntas antes de aceptar la entrevista y a pesar de la insistencia, no se concretó.

- En esta investigación las brechas no fueron un impedimento, si bien cierto no se lograron las entrevistas planeadas, se logró cumplir el objetivo y alcanzar el desarrollo del análisis de la investigación. 


\subsection{Conclusiones}

- Se valida de manera parcial nuestra hipótesis general de la investigación, debido a que se validó por cada variable estudiada. Los turnos de trabajo y la remuneración básica afectan principalmente la rotación de los asesores telefónicos y las condiciones contractuales, no afectan principalmente, según la investigación.

- En la mayoría de los Centros de Contacto investigados, cuentan con diferentes horarios que varían por inicio y término de cada campaña, lo que no les permite tener estabilidad para que puedan continuar con sus estudios o alguna actividad paralela. Algunos de los Centros de Contactos investigados otorgan una excepción en la flexibilidad de horarios, siempre y cuando se encuentre cursando una actividad académica; esto afectaría significativamente la rotación de asesores telefónicos.

- Las condiciones contractuales no afectan principalmente la rotación. Según la mayoría de entrevistados indican que los más jóvenes firman su contrato sin tener conocimiento de la modalidad o tipo de contratos establecidos. Además, consideran que el tiempo es razonable para insertarse al rubro de Centros de Contacto. Sin embargo, la edad y la experiencia de cada asesor telefónico, es importante para poder mantener su estabilidad laboral.

- La remuneración referente al sueldo base afecta principalmente la rotación. Los asesores telefónicos de los Centros de Contacto sujetos de estudio en la investigación no están conformes con su sueldo base y para el Segmento A, mencionan que la remuneración variable percibida es muy baja, a diferencia del Segmento B, si se encuentran conformes porque consideran que las comisiones son altas, además de los diferentes incentivos percibidos. Para ambos segmentos refieren que, si no llegan a sus metas o indicadores, no podrán comisionar y solo recibirán su sueldo base.

- La remuneración promedio de los Centros de Contacto, no es igual en comparación a los Centros de Contacto administrados por entidades bancarias investigados, debido a las exigencias de las políticas de remuneración y perfil académico establecido en cada uno de ellos. 


\subsection{Recomendaciones}

- Se recomienda realizar periódicamente encuestas de satisfacción a los asesores telefónicos a través de medios virtuales, con el objetivo de conocer que tan satisfechos o insatisfechos se encuentran sobre los beneficios que el Centro de Contacto les brinda, por ejemplo, con respecto a los turnos de trabajo establecidos en cada campaña y a la vez, con la información recolectada realizar un estudio a profundidad para implementar mejoras y poder retener el recurso humano.

- Se recomienda que los contratos se elaboren con términos más específicos y entendibles para los asesores telefónicos y que puedan evaluar la reducción de números de horas efectivas laboradas para que el asesor telefónico tenga más tiempo para realizar otras actividades, además de minimizar el estrés por la gestión.

- Se recomienda que en futuras investigaciones se realice un estudio de los indicadores salariales que establecen en los centros de Contacto, para conocer si realmente son alcanzables de acuerdo con la labor de cada asesor telefónico.

- El supervisor o jefe de área debería darle mayor seguimiento al asesor telefónico a través de la retroalimentación, podría realizar una entrevista de salida, a fin de conocer realmente las causas de las renuncias de su personal y posteriormente establecer acciones que permitan disminuir la rotación su área. 


\section{CAPÍTULO V - BIBLIOGRAFÍA}

\section{Referencias bibliográficas}

Ackerman y otros (pág 415)

Alles, M. (2015). Dirección Estratégica de Recursos Humanos (Vol. Gestión de Competencias). Granica.

Arroyo Gamboa, Y. K. (2014). La Gestión de Recursos Humanos y la Tasa de Rotación de personal en la empresa Compartamos Financiera, sucursal Trujillo. Trujillo: Universidad Nacional de Trujillo.

Arteaga, C. F. (Marzo de 2016). Propuesta para disminuir la rotación de personal en la sucursal American Call Center Quito - 2016. Quito, Ecuador: Universidad Central de Ecuador.

Byars, L. L., \& Rue, L. W. (1996). Gestión de Recursos Humanos (Cuarta ed.). IRWIN.

Castillo Aponte, J. (2006). Administración de personal: un enfoque hacia la calidad. ECOE Ediciones.

Chiavenato, I. (2002). Gestión del Talento Humano: El nuevo papel de los recursos humanos en las organizaciones. Mc Graw Hill.

Chiavenato, I. (2009). Gestión del Talento Humano. En I. Chiavenato, Gestión del Talento Humano (3era Edición ed., pág. 91). MC Graw - Hill / Interamericana Editores CA.DCV.

Cleveland, B. (2008). (1 de junio del 2005) Tackling Turnover. Call Center.16. En L. GómezMejía, D. Balkin, \& R. Cardy, Gestión de recursos humanos (5ta ed., pág. 228). Person Prentice Hall.

Dale, Y. (1983). Manejo de Personal y Relaciones Industriales, Cia (9 ed.). México, México: Continental S.A.

Desposorio Jara, M. E. (2016). Los incentivos laborales y su influencia en la productividad de la empresa Call Center Teleatento del Perú SAC, Plataforma BBVA Continental. Trujillo.

Gómez, L. R., Balkin, D. B., \& Cardy, R. L. (2008). Gestión de Recursos Humanos (5a ed. ed.). 
Gómez-Mejía, L., Balkin, D., \& Cardy, R. (2008). Gestión de recursos humanos (5a Edición ed.). Pearson Prentice Hall.

Guevara Campos, R. X., Paxi Arocutipa, R. A., \& Arratia Chucuya, J. A. (2016). Plan de mejora para disminuir la alta rotación de los teleoperadores en la empresa Olva Contact Center. Tacna: Instituto de Educación Superior Tecnológico Privado Jhon Von Neuman.

Hernández Sampieri, R. (s.f.). Metodología de la Investigación. Mc Graw Hill.

Louffat, E. (2010). Administración del Potencial Humano (1 ed.). Argentina: Cengage Learning .

Medellín Henao, M. F. (2013). Incidencia de la motivación en la rotación de personal de la empresa Digitex Internacional. Caldas, Colombia: Universidad Nacional de Colombia Sede Manizales.

Medrano López, D. L. (2010). Satisfacción Laboral y Rotación de Personal en los Agentes Teleoperadores en el Call Center "Icon Media Center" de la Ciudad de Tacna durante el último trimestre del año 2010. Tacna.

Milkovich, G., \& Boudreau, J. (1997). Dirección y Administración de Recursos Humanos: Un enfoque de estrategia (6 edición ed.). México D.F.: Adisson Wesley.

Mondragón Chavarrí, N. (2013). La motivación laboral extrínseca y su relación con el fenómeno de rotación de personal de los ejecutivos telefónicos de grupo telemarketing profesional service. México.

Morris, E., Ancajima, A., Chiri, C., Galindo, J., Guido , C., \& Mejía, E. (2009). Gerencia Global 14: Servicios de contact center basados en offshore outsourcing. Lima: Editorial Cordillera S.A.C.

Peña Arévalo, K. J. (2016). Las causas de rotación de personal incorporado por E-recruitment en el Grupo Telestant. Trujillo: Universidad César Vallejo.

Rodríguez. (1998). Introducción a la Psicología del trabajo .

Rodríguez Aliaga, D. K. (2016). Los incentivos laborales y su influencia en el rendimiento de los colaboradores del centro de contacto del Banco de Crédito del Perú sucursal . La Esperanza.

Ruiz Bazán, G. L. (2016). Factores de rotación de personal en el Call Center del Banco de Crédito del Perú -Cobtel. Trujillo: Universidad César Vallejo. 
Salazar Prado, T. M. (2016). Identificación de los factores que determinan la alta rotación del personal de ventas en empresas retail de prendas de vestir: Caso Tiendas Piero. Universidad de Lima.

Strauss, A. L., \& Corbin, J. (1990). Basics of Qualitative Research: Grounded theory, procedures and techniques. Newbury Park, C.A.: Sage Publications.

Weiss, D. y. (1993). La función de los Recursos Humanos. En C. Bourreau, \& G. Mignotte. Madrid: CND Ciencias de la Dirección.

Werther, W. B., \& Davis, K. (2000). Administración de Personal y Recursos Humanos (Quinta ed.). México: McGraw- Hill Interamericana Editores, S.A. de C.V.

Wikipedia . (31 de Agosto de 2017). Wikipedia La enciclopedia libre. Obtenido de https://es.wikipedia.org/wiki/Centro_de_llamadas

\section{Referencia Virtual}

APECCO. (18 de junio del 2017). Obtenido de la Página Web:

http://www.apecco.org/cms/?page_id=4407

Diario El Comercio. (23 de octubre de 2014). Obtenido de El Comercio:

http://elcomercio.pe/economia/peru/mitad-empleados-call-centers-son-primerizos-179030

Diario Gestión (18 de junio de 2017). Obtenido de Gestión:

http://gestion.pe/economia/call-centers-peru-chile-y-colombia-lideran-su-crecimiento-region2192822

PROMPERÚ. (18 de junio del 2017). Obtenido de la Página Web:

https://www.promperu.gob.pe/ 


\section{Anexo 1. Matriz de consistencia}

\begin{tabular}{|c|c|c|c|}
\hline $\begin{array}{l}\text { PROBLEMA } \\
\text { GENERAL }\end{array}$ & $\begin{array}{l}\text { OBJETIVO } \\
\text { GENERAL }\end{array}$ & HIPÓTESIS GENERAL & VARIABLES \\
\hline $\begin{array}{lr}\text { ¿Cuáles son los } \\
\text { factores que afectan la } \\
\text { rotación de los } \\
\text { asesores telefónicos en } \\
\text { los Centros de } \\
\text { Contacto de Lima } \\
\text { Metropolitana? }\end{array}$ & $\begin{array}{l}\text { Identificar los factores } \\
\text { que afectan la rotación } \\
\text { de los asesores } \\
\text { telefónicos en los } \\
\text { Centros de Contacto de } \\
\text { Lima Metropolitana. }\end{array}$ & $\begin{array}{l}\text { Los factores que afectan } \\
\text { principalmente la rotación } \\
\text { son el turno de trabajo, las } \\
\text { condiciones contractuales } \\
\text { y la remuneración de los } \\
\text { asesores telefónicos en los } \\
\text { Centros de Contacto de } \\
\text { Lima Metropolitana. }\end{array}$ & $\begin{array}{l}\text { - Turno de } \\
\text { trabajo }\end{array}$ \\
\hline $\begin{array}{c}\text { PROBLEMAS } \\
\text { ESPECÍFICOS. - }\end{array}$ & $\begin{array}{c}\text { OBJETIVO } \\
\text { ESPECÍFICOS }\end{array}$ & $\begin{array}{c}\text { HIPÓTESIS } \\
\text { ESPECÍFICAS }\end{array}$ & contractuale \\
\hline $\begin{array}{l}\text { 1. ¿Es el turno de } \\
\text { trabajo un factor que } \\
\text { afecta la rotación de } \\
\text { los asesores } \\
\text { telefónicos en los } \\
\text { Centros de Contacto } \\
\text { de Lima } \\
\text { Metropolitana? } \\
\text { 2. ¿Las condiciones } \\
\text { contractuales son } \\
\text { factores que afectan la } \\
\text { rotación los asesores } \\
\text { telefónicos en los } \\
\text { Centros de Contacto } \\
\text { de Lima } \\
\text { Metropolitana? } \\
\text { 3. ¿La remuneración } \\
\text { es un factor que afecta } \\
\text { la rotación de los } \\
\text { asesores telefónicos en } \\
\text { los Centros de } \\
\text { Contacto de Lima } \\
\text { Metropolitana? }\end{array}$ & $\begin{array}{l}\text { 1. Identificar cuáles son } \\
\text { los turnos de trabajo y } \\
\text { en qué medida afecta a } \\
\text { los asesores telefónicos } \\
\text { en los Centros de } \\
\text { Contacto de Lima } \\
\text { Metropolitana. } \\
\text { 2. Identificar cuáles son } \\
\text { las condiciones } \\
\text { contractuales } \\
\text { establecidas } \\
\text { frecuentemente en los } \\
\text { Centros de Contacto de } \\
\text { Lima Metropolitana. } \\
\text { 3. Identificar cuáles son } \\
\text { los componentes de la } \\
\text { remuneración } \\
\text { establecidos } \\
\text { frecuentemente en los } \\
\text { Centros de Contacto de } \\
\text { Lima Metropolitana. }\end{array}$ & $\begin{array}{l}\text { 1. El turno de trabajo es un } \\
\text { factor que afecta } \\
\text { principalmente la rotación } \\
\text { de los asesores telefónicos } \\
\text { en los Centros de Contacto } \\
\text { de Lima Metropolitana. } \\
\text { 2. Las condiciones } \\
\text { contractuales son factores } \\
\text { que afectan principalmente } \\
\text { la rotación de los asesores } \\
\text { telefónicos en los Centros } \\
\text { de Contacto de Lima } \\
\text { Metropolitana. } \\
\text { 3. La remuneración es un } \\
\text { factor que afecta } \\
\text { principalmente la rotación } \\
\text { de los asesores telefónicos } \\
\text { en los Centros de Contacto } \\
\text { de Lima Metropolitana. }\end{array}$ & - $\underset{\mathrm{n}}{\text { Remuneració }}$ \\
\hline
\end{tabular}




\section{Anexo 2. Cuadro control de aplicación de entrevistas por cada segmento}

$\underline{\text { Segmento A (Asesores telefónicos de Centros de Contacto) }}$

\begin{tabular}{|l|l|}
\hline Centro de Contacto & Tercerizador de Servicios \\
\hline Sector de Servicio & Área de Cobranzas y Área de Ventas \\
\hline Edad & 24 a 42 años \\
\hline Sexo & Femenino o Masculino \\
\hline Tiempo de permanencia en el CC & Mayor a 4 meses \\
\hline Turno de trabajo & Indiferente \\
\hline Lugar & Lima Metropolitana \\
\hline
\end{tabular}

$\underline{\text { Segmento B (Asesores telefónicos de Centros de Contacto administrados por entidades bancarias) }}$

\begin{tabular}{|l|l|}
\hline Centro de Contacto & Administrado por Entidades Financieras \\
\hline Sector de Servicio & Área de Cobranzas y área de Ventas \\
\hline Edad & 24 a 42 años \\
\hline Sexo & Femenino o Masculino \\
\hline Tiempo de permanencia en el CC & Mayor a 1 año \\
\hline Turno de trabajo & Indiferente \\
\hline Lugar & Lima Metropolitana \\
\hline
\end{tabular}


$\underline{\text { Segmento C (Supervisores, jefes de área o gerentes de Recursos Humanos de Centros de Contacto) }}$

\begin{tabular}{|l|l|}
\hline Sector de Servicio & $\begin{array}{l}\text { Tercerizador de Servicios y } \\
\text { Administrado por Entidades Financieras }\end{array}$ \\
\hline Edad & Indiferente \\
\hline Sexo & Femenino o Masculino \\
\hline Tiempo de permanencia en el CC & Mayor a 2 años \\
\hline Turno de trabajo & Indiferente \\
\hline Lugar & Lima Metropolitana \\
\hline
\end{tabular}

$\underline{\text { Segmento D (Especialistas en el sector de servicios de Centros de Contacto) }}$

\begin{tabular}{|l|l|}
\hline Sector de Servicio & Centros de Contacto \\
\hline Edad & Indiferente \\
\hline Sexo & Femenino o Masculino \\
\hline Experiencia en el Sector & Mayor a 10 años \\
\hline Turno de trabajo & Indiferente \\
\hline Lugar & Lima Metropolitana \\
\hline
\end{tabular}


Anexo 03. Descripción del contexto interno

\begin{tabular}{|c|c|c|c|c|}
\hline $\begin{array}{l}\text { SEGMENTO / } \\
\text { CONTEXTO }\end{array}$ & $\begin{array}{c}\text { SEGMENTO A } \\
\text { Asesores telefónicos de } \\
\text { centros de contacto de Lima } \\
\text { Metropolitana. }\end{array}$ & $\begin{array}{c}\text { SEGMENTO B } \\
\text { Asesores telefónicos de centros } \\
\text { de contactos administrados por } \\
\text { entidades bancarias. }\end{array}$ & $\begin{array}{c}\text { SEGMENTO C } \\
\text { Supervisores, Jefes de áreas o } \\
\text { Gerentes de Recursos Humanos. }\end{array}$ & $\begin{array}{c}\text { SEGMENTO D } \\
\text { Especialistas en el sector de Centros de } \\
\text { Contacto }\end{array}$ \\
\hline $\begin{array}{l}\text { Experiencia en } \\
\text { el sector }\end{array}$ & $\begin{array}{l}\text { Con experiencia en Ventas y } \\
\text { Cobranzas, más de } 4 \text { meses. }\end{array}$ & $\begin{array}{l}\text { Con experiencia en Ventas y } \\
\text { Cobranzas, más de } 1 \text { año. }\end{array}$ & Con experiencia más de 2 años. & Con experiencia más de 10 años. \\
\hline $\begin{array}{l}\text { Información de } \\
\text { las variables de } \\
\text { estudio }\end{array}$ & $\begin{array}{l}\text { Horarios rotativos } \\
\text { establecidos por campañas. } \\
\text { Firman renovaciones de } \\
\text { contratos cada } 3 \text { meses. } \\
\text { Su sueldo base es } 850 \text { soles. } \\
\text { Sueldo promedio } 1,500 \text { soles } \\
\text { mensuales }\end{array}$ & $\begin{array}{l}\text { Existen turnos fijos, dos } \\
\text { horarios establecidos como } \\
\text { máximo. } \\
\text { Firman renovaciones de } \\
\text { contratos cada } 6 \text { meses. } \\
\text { Sueldo base es } 750 \text { soles a más. } \\
\text { Sueldo promedio } 3,000 \text { soles }\end{array}$ & $\begin{array}{l}\text { Los turnos son establecidos } \\
\text { según el cliente. } \\
\text { La renovación de contratos es } \\
\text { de acuerdo con una evaluación } \\
\text { de desempeño. } \\
\text { El sueldo promedio está acorde } \\
\text { con el mercado. }\end{array}$ & $\begin{array}{l}\text { La edad promedio de asesores es de } 18 \text { a } \\
45 \text { años. } \\
\text { Los turnos son rotativos. } \\
\text { La renovación está de acuerdo con el } \\
\text { desempeño. } \\
\text { El sueldo promedio está acorde con el } \\
\text { mercado. }\end{array}$ \\
\hline $\begin{array}{l}\text { Factores que } \\
\text { afectan la } \\
\text { rotación }\end{array}$ & $\begin{array}{l}\text { Las renuncias se deben a que } \\
\text { no llegan a sus metas, por lo } \\
\text { tanto, no comisionan y solo } \\
\text { perciben su salario base. } \\
\text { No toleran el trabajo bajo } \\
\text { presión. } \\
\text { No se adaptan rápidamente a } \\
\text { la labor. } \\
\text { Desvinculación por término } \\
\text { de campaña. } \\
\text { El tiempo de permanencia es } \\
\text { de } 3 \text { a } 6 \text { meses. }\end{array}$ & $\begin{array}{l}\text { La rotación es mínima. } \\
\text { Las renuncias en su mayoría } \\
\text { son voluntarias. } \\
\text { La exigencia para el } \\
\text { cumplimiento de las metas } \\
\text { establecida es de acuerdo con el } \\
\text { perfil del asesor y en el área en } \\
\text { el que esté ubicado. } \\
\text { El tiempo de permanencia es de } \\
2 \text { años. }\end{array}$ & $\begin{array}{l}\text { En el Segmento } \quad \text { B, las } \\
\text { renuncias se deben a } \\
\text { oportunidades, }\end{array}$ & $\begin{array}{l}\text { Jóvenes entre } 18 \text { a } 20 \text { años sin } \\
\text { responsabilidades, trabajan para cubrir } \\
\text { sus necesidades básicas o temporales. } \\
\text { Las condiciones laborales no son las más } \\
\text { adecuadas en algunos Centros de } \\
\text { Contacto. } \\
\text { Los Centros de Contacto no se } \\
\text { diferencian porque todos brindan el } \\
\text { mismo servicio. } \\
\text { Existe desconocimiento por parte de los } \\
\text { asesores telefónicos sobre las leyes } \\
\text { laborales. }\end{array}$ \\
\hline $\begin{array}{l}\text { Información } \\
\text { Adicional }\end{array}$ & $\begin{array}{l}\text { Indican que los cambios de } \\
\text { horarios son avisados hasta } \\
\text { con un día de anticipación. }\end{array}$ & $\begin{array}{l}\text { Asesores con carga familiar o } \\
\text { estudios son los que menos } \\
\text { rotan. }\end{array}$ & $\begin{array}{l}\text { En el Segmento A, el perfil del } \\
\text { asesor telefónico varía en } \\
\text { función con el contrato que se } \\
\text { firma con la empresa. }\end{array}$ & $\begin{array}{l}\text { El sector de Centros de Contacto es un } \\
\text { trabajo temporal para la mayoría los } \\
\text { asesores telefónicos y para otros es }\end{array}$ \\
\hline
\end{tabular}




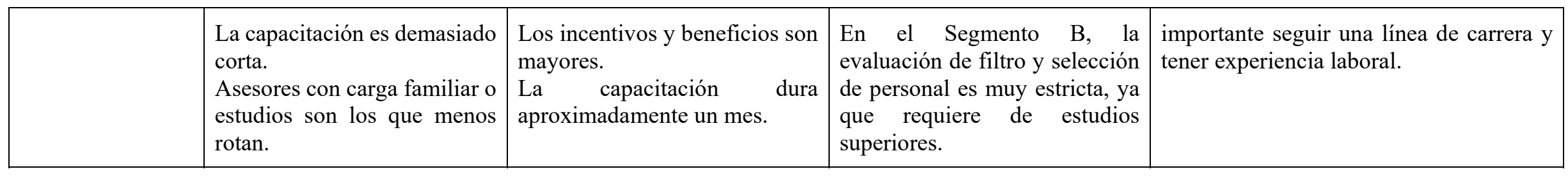




\section{Anexo 4. Descripcion del contexto externo}

\begin{tabular}{|c|c|c|c|c|}
\hline $\begin{array}{l}\text { ENTREVISTADO } \\
\text { S/CATEGORÍAS }\end{array}$ & $\begin{array}{c}\text { SEGMENTO A } \\
\text { Asesores telefónicos de } \\
\text { centros de contacto de Lima } \\
\text { Metropolitana. }\end{array}$ & $\begin{array}{l}\text { SEGMENTO B } \\
\text { Asesores telefónicos de } \\
\text { centros de contactos } \\
\text { administrados por } \\
\text { entidades bancarias. }\end{array}$ & $\begin{array}{c}\text { SEGMENTO C } \\
\text { Supervisores, Jefes de } \\
\text { áreas o Gerentes de } \\
\text { Recursos Humanos. }\end{array}$ & $\begin{array}{c}\text { SEGMENTO D } \\
\text { Especialistas en el sector de } \\
\text { Centros de Contacto }\end{array}$ \\
\hline $\begin{array}{l}\text { Observaciones } \\
\text { antes de la } \\
\text { entrevista }\end{array}$ & $\begin{array}{l}\text { Se tuvo dificultad para } \\
\text { concretar las entrevistas } \\
\text { debido a la falta de tiempo. } \\
\text { Las entrevistas se coordinaron } \\
\text { vía correo electrónico, en } \\
\text { primera instancia no se obtuvo } \\
\text { respuestas favorables por } \\
\text { temas laborales en los Centros } \\
\text { de Contacto. }\end{array}$ & $\begin{array}{l}\text { Las entrevistas se } \\
\text { coordinaron vía telefónica, } \\
\text { respondieron de forma muy } \\
\text { amable y se pactó el lugar, } \\
\text { fecha, según su } \\
\text { disponibilidad. }\end{array}$ & $\begin{array}{l}\text { Las coordinaciones se } \\
\text { gestionaron vía correo } \\
\text { electrónico, concretando } \\
\text { fecha y lugar. En el caso de } \\
\text { los supervisores de } \\
\text { Interbank y del BCP, las } \\
\text { entrevistas fueron pactadas } \\
\text { vía telefónica. }\end{array}$ & $\begin{array}{l}\text { Se coordinaron las entrevistas a } \\
\text { través de cartas de presentación y } \\
\text { se obtuvo respuesta de los tres } \\
\text { especialistas. Respondieron en } \\
\text { forma positiva y se gestionó por } \\
\text { correo electrónico fecha y lugar de } \\
\text { las entrevistas pactadas. }\end{array}$ \\
\hline $\begin{array}{l}\text { Observaciones } \\
\text { durante la } \\
\text { entrevista }\end{array}$ & $\begin{array}{l}\text { Brindaron } \\
\text { relevante de cada una de } \\
\text { nuestras variables de } \\
\text { investigación. Se mostraron } \\
\text { nerviosos por la entrevista } \\
\text { filmada. } \\
\text { Los asesores telefónicos } \\
\text { colaboraron en brindarnos } \\
\text { referencia para contactar a sus } \\
\text { supervisores. }\end{array}$ & $\begin{array}{l}\text { No hubo oposición en } \\
\text { grabar las entrevistas. Los } \\
\text { entrevistados brindaron } \\
\text { información relevante. }\end{array}$ & $\begin{array}{l}\text { Cada uno de los } \\
\text { entrevistados nos brindó } \\
\text { información en base a } \\
\text { nuestras variables de } \\
\text { investigación. } \\
\text { La mayoría de las } \\
\text { entrevistas fueron grabadas } \\
\text { en el interior de sus } \\
\text { oficinas. }\end{array}$ & $\begin{array}{l}\text { Cada uno de los entrevistados } \\
\text { dominaba su campo, el ambiente } \\
\text { de la entrevista fue cómodo, se } \\
\text { realizó en una oficina } \\
\text { proporcionada especialmente por } \\
\text { el entrevistado. }\end{array}$ \\
\hline
\end{tabular}




\begin{tabular}{|c|c|c|c|c|}
\hline $\begin{array}{l}\text { Observaciones } \\
\text { después de la } \\
\text { entrevista }\end{array}$ & $\begin{array}{l}\text { No hubo oposición en grabar } \\
\text { las entrevstas. Los } \\
\text { entrevistados brindaron } \\
\text { información extra fuera del } \\
\text { estudio, cada uno escogió el } \\
\text { horario y lugar de entrevista. }\end{array}$ & $\begin{array}{l}\text { Nos brindaron información } \\
\text { completa y detallada de su } \\
\text { experiencia en el sector. }\end{array}$ & $\begin{array}{l}\text { Los entrevistados nos } \\
\text { ofrecieron algunas } \\
\text { referencias para } \\
\text { contactarnos con jefes de } \\
\text { otros Centros de contacto. } \\
\text { Les pareció importante el } \\
\text { tema de investigación. }\end{array}$ & $\begin{array}{l}\text { Se obtuvo información del sector. } \\
\text { Se recibió información adicional } \\
\text { por medios electrónicos. } \\
\text { Asimismo, con contactos } \\
\text { referenciales. }\end{array}$ \\
\hline $\begin{array}{l}\text { Conclusiones } \\
\text { generales por } \\
\text { segmento }\end{array}$ & $\begin{array}{l}\text { Se recolectó información } \\
\text { variada acerca de los factores } \\
\text { que pueden afectar la rotación } \\
\text { de asesores telefónicos. }\end{array}$ & $\begin{array}{l}\text { Se logró realizar la } \\
\text { comparación de las } \\
\text { variables de estudio con el } \\
\text { segmento objetivo. }\end{array}$ & $\begin{array}{l}\text { La información obtenida } \\
\text { referente al tema fue } \\
\text { contrastada con las } \\
\text { variables, según los } \\
\text { segmentos investigados. }\end{array}$ & $\begin{array}{l}\text { Las entrevistas fueron de gran } \\
\text { ayuda para nuestro tema de } \\
\text { investigación. }\end{array}$ \\
\hline
\end{tabular}




\section{Anexo 5. Guía de preguntas para las entrevistas de profundidad a los asesores telefónicos de los centros de contacto y de centros de contacto administradas por entidades bancarias de Lima Metropolitana}

\begin{tabular}{|c|c|}
\hline Clase & Preguntas \\
\hline $\begin{array}{c}\text { Experiencia en el } \\
\text { sector }\end{array}$ & $\begin{array}{l}\text { ¿Cuál es su nombre? ¿Qué edad tiene? } \\
\text { ¿En qué área del Centro de Contacto labora? } \\
\text { ¿Cuánto tiempo tiene laborando en este Centro de Contacto? } \\
\text { ¿Ha trabajado en otro Centro de Contacto? } \\
\text { ¿El porqué de su elección en trabajar en un Centro de Contacto? }\end{array}$ \\
\hline $\begin{array}{l}\text { Información de } \\
\text { las variables de } \\
\text { los turnos de } \\
\text { trabajo. }\end{array}$ & $\begin{array}{l}\text { Me gustaría conocer ¿Cómo es el sistema de llamadas? } \\
\text { ¿Cuáles son los turnos de trabajo? Horarios de turnos de trabajo, } \\
\text { refrigerio, descansos, entre otros. } \\
\text { Existen cambios de horarios. ¿Son informados a tiempo? } \\
\text { ¿Considera que su horario le permite tener actividades paralelas? ¿Le } \\
\text { permite estudiar? ¿Alguna otra actividad paralela? }\end{array}$ \\
\hline $\begin{array}{l}\text { Información de } \\
\text { las variables de } \\
\text { condiciones } \\
\text { contractuales. }\end{array}$ & $\begin{array}{l}\text { ¿Cómo es la modalidad de contratación? } \\
\text { ¿Cada cuánto tiempo renuevan contrato? ¿Qué tipo de contrato } \\
\text { firman? } \\
\text { ¿Se especifica su turno de trabajo en el contrato? }\end{array}$ \\
\hline $\begin{array}{l}\text { Información de } \\
\text { las variables de } \\
\text { remuneración. }\end{array}$ & $\begin{array}{l}\text { Coméntenos ¿Cómo es el sistema de remuneración? } \\
\text { (Sueldo base, variables, incentivos, beneficios y sueldo promedio) } \\
\text { Considera que lo percibido está acorde con sus labores diarias. }\end{array}$ \\
\hline $\begin{array}{l}\text { Factores que } \\
\text { afectan la } \\
\text { rotación. }\end{array}$ & $\begin{array}{l}\text { En su experiencia laboral, ¿Cada cuánto tiempo observa usted, que } \\
\text { renuncian e ingresan nuevos asesores telefónicos en su área? ¿Cuánto } \\
\text { tiempo es el periodo de capacitación? ¿Cuánto tiempo es su periodo } \\
\text { de prueba? } \\
\text { ¿Cuál es el principal motivo de permanecer en este centro de } \\
\text { Contacto? }\end{array}$ \\
\hline $\begin{array}{c}\text { Información } \\
\text { adicional. }\end{array}$ & $\begin{array}{l}\text { ¿Desearía dejarnos algún comentario adicional con respecto al tema } \\
\text { tratado? Opinión personal sobre los factores que puedan afectar la } \\
\text { rotación de asesores telefónicos. }\end{array}$ \\
\hline
\end{tabular}


Anexo 6. Guía de preguntas para las entrevistas de profundidad a los supervisores, jefes $\mathrm{y} / \mathrm{o}$ gerentes de los centros de contacto de Lima Metropolitana

\begin{tabular}{|c|c|}
\hline Clase & Preguntas \\
\hline $\begin{array}{c}\text { Experiencia en el } \\
\text { sector }\end{array}$ & $\begin{array}{l}\text { ¿Cuál es su cargo en el Centro de Contacto? } \\
\text { ¿Cuánto tiempo tiene laborando para este Centro de Contacto? } \\
\text { ¿Cómo se inició en el Centro de Contacto? ¿Ha realizado línea de } \\
\text { carrera? } \\
\text { ¿Cuál es el tipo de organización o estructura organizacional en su } \\
\text { Centro de Contacto? ¿Cómo es la comunicación de supervisor a } \\
\text { asesor telefónico? } \\
\text { ¿Cuál es el perfil del asesor telefónico en su área? } \\
\text { ¿Cuántos asesores telefónicos están a su cargo? }\end{array}$ \\
\hline $\begin{array}{l}\text { Información de } \\
\text { las variables de } \\
\text { los turnos de } \\
\text { Trabajo. }\end{array}$ & $\begin{array}{l}\text { ¿Cómo es el sistema de operación de llamadas? } \\
\text { ¿Cuál es la política establecida de los turnos de trabajo de los asesores } \\
\text { telefónicos? } \\
\text { ¿Tienen turnos de trabajo rotativos? } \\
\text { ¿Su turno de trabajo está especificado en su contrato laboral? }\end{array}$ \\
\hline $\begin{array}{l}\text { Información de } \\
\text { las variables de } \\
\text { modalidades } \\
\text { contractuales. }\end{array}$ & $\begin{array}{l}\text { ¿Cómo es la modalidad de contratación del asesor telefónico? ¿Qué } \\
\text { porcentaje de asesores telefónicos tienen contratos temporales, } \\
\text { indeterminados u otros? } \\
\text { Sobre los tipos y duración de contratos aplicados a los asesores } \\
\text { telefónicos: } \\
\text { ¿Cuál es el porcentaje de contratos que se renuevan a los asesores } \\
\text { telefónicos? }\end{array}$ \\
\hline $\begin{array}{l}\text { Información de } \\
\text { las variables de } \\
\text { remuneración. }\end{array}$ & $\begin{array}{l}\text { ¿Cuál es la política de remuneración del asesor telefónico? ¿Tienen } \\
\text { sueldo básico y sueldo variable? } \\
\text { ¿Considera que la remuneración establecida para un asesor telefónico } \\
\text { se encuentra en promedio con la del mercado laboral? }\end{array}$ \\
\hline $\begin{array}{l}\text { Factores que } \\
\text { afectan la } \\
\text { rotación. }\end{array}$ & $\begin{array}{l}\text { ¿Cuál es el porcentaje de asesores telefónicos que no les renuevan } \\
\text { contrato y en qué periodo de tiempo? } \\
\text { ¿Cuáles son los motivos más frecuentes de renuncia? ¿Qué } \\
\text { porcentaje de renuncias hay, voluntarias e involuntarias? } \\
\text { ¿Cuánto es el tiempo de permanencia de un asesor telefónico en su } \\
\text { área? } \\
\text { ¿Tienen asesores telefónicos de manera permanente en el Centro de } \\
\text { Contacto? } \\
\text { ¿Cuál es el índice de rotación de asesores telefónicos en su área? }\end{array}$ \\
\hline
\end{tabular}



rotación de asesores telefónicos. 


\section{Anexo 7. Guía de preguntas para las entrevistas de profundidad a los especialistas de los centros de contacto de Lima Metropolitana}

\begin{tabular}{|c|c|}
\hline Clase & Preguntas \\
\hline $\begin{array}{l}\text { Experiencia } \\
\text { en el sector }\end{array}$ & $\begin{array}{l}\text { ¿Podría hablarnos del sector de Centros de Contacto en Lima } \\
\text { Metropolitana? } \\
\text { ¿Cuál es el servicio que tiene mayor demanda? Gestión de cobranzas, } \\
\text { atención al cliente, ventas y tele marketing, mesa de ayuda, gestión de } \\
\text { base de datos y fidelización. } \\
\text { ¿Cuántas empresas dedicadas al sector de Centros de Contacto existen en } \\
\text { Lima Metropolitana? } \\
\text { ¿Cuántos asesores telefónicos hay en el sector de Centros de Contacto } \\
\text { en Lima Metropolitana? }\end{array}$ \\
\hline $\begin{array}{l}\text { Información } \\
\text { de las } \\
\text { variables de } \\
\text { estudio }\end{array}$ & $\begin{array}{l}\text { ¿Cuál es la edad promedio de asesores telefónicos que contratan los } \\
\text { Centros de Contacto? } \\
\text { ¿Cuántas horas promedio trabajan los asesores telefónicos en los Centros } \\
\text { de Contacto? } \\
\text { ¿Cuál es la remuneración promedio de los asesores telefónicos en los } \\
\text { Centros de Contacto? } \\
\text { ¿Cuál es el tiempo de permanencia de los asesores telefónicos en los } \\
\text { Centros de Contacto? }\end{array}$ \\
\hline $\begin{array}{l}\text { Factores que } \\
\text { afectan la } \\
\text { rotación }\end{array}$ & $\begin{array}{l}\text { ¿Cuál es el índice de rotación de los asesores telefónicos en los Centros } \\
\text { de Contacto en Lima Metropolitana? } \\
\text { ¿Con este índice de crecimiento existe mayor empleabilidad para los } \\
\text { jóvenes que buscan obtener su primera experiencia laboral? } \\
\text { ¿Usted cree, que existe potencial de crecimiento en este sector? }\end{array}$ \\
\hline $\begin{array}{c}\text { Información } \\
\text { Adicional }\end{array}$ & $\begin{array}{l}\text { ¿Desearía dejarnos algún comentario adicional con respecto al tema } \\
\text { tratado? Opinión personal sobre los factores que puedan afectar la } \\
\text { rotación de asesores telefónicos. }\end{array}$ \\
\hline
\end{tabular}


Tabla 4. Observaciones de la entrevista (Segmento A, Maritza, 42 años)

\begin{tabular}{|c|c|}
\hline $\begin{array}{l}\text { Contexto } \\
\text { /Segmento }\end{array}$ & Asesor Telefónico \\
\hline $\begin{array}{l}\text { Observaciones } \\
\text { antes de la } \\
\text { entrevista }\end{array}$ & $\begin{array}{l}\text { La entrevista se coordinó directamente con la gerente de Recursos } \\
\text { Humanos, la cual nos ayudó a concretar la entrevista dentro del } \\
\text { horario de trabajo del asesor telefónico, para el día miércoles } 15 \text { de } \\
\text { noviembre del } 2017 \text { a las } 02: 30 \mathrm{pm} \text { en las instalaciones del Centro de } \\
\text { Contacto de HDC. } \\
\text { La entrevistada tiene } 4 \text { meses en la empresa. En un inicio se solicitó } \\
\text { a un asesor con mayor tiempo en el Centro de Contacto, pero por } \\
\text { motivos de la misma gerencia no tuvimos éxito. }\end{array}$ \\
\hline $\begin{array}{l}\text { Observaciones } \\
\text { durante la } \\
\text { entrevista }\end{array}$ & $\begin{array}{l}\text { La entrevista se desarrolló en una oficina pequeña de uno de los } \\
\text { supervisores de la empresa, en la misma oficina se concretó otra } \\
\text { entrevista con otro asesor de igual tiempo en la empresa, el } \\
\text { supervisor permaneció todo el tiempo de la entrevista en su oficina, } \\
\text { dificultando la entrevista por el ruido ocasionado y la incomodidad } \\
\text { de las personas entrevistadas. } \\
\text { La entrevistada estaba un poco nerviosa, luego se la observó relajada } \\
\text { respondiendo a todas nuestras preguntas. }\end{array}$ \\
\hline $\begin{array}{l}\text { Observaciones } \\
\text { después de la } \\
\text { entrevista }\end{array}$ & $\begin{array}{l}\text { La entrevistada brindó información básica del tema tratado, ya que } \\
\text { al ser entrevistada en la misma oficina de unos de los supervisores } \\
\text { del área, si bien se la notaba un poco nerviosa, después no quería } \\
\text { dejar de ser entrevistada, porque entró en confianza. }\end{array}$ \\
\hline $\begin{array}{l}\text { Conclusión } \\
\text { general de la } \\
\text { entrevista del } \\
\text { asesor telefónico. }\end{array}$ & $\begin{array}{l}\text { La rotación se debe a la falta de conocimiento de los asesores } \\
\text { telefónicos con la labor que se realiza en el Centro de Contacto, } \\
\text { debido a que el tiempo de capacitación es muy corto. } \\
\text { Los jóvenes no se sienten realmente motivados por la labor } \\
\text { realizada, ya que las comisiones son muy bajas. }\end{array}$ \\
\hline
\end{tabular}


Tabla 5. Ficha de la entrevista (Segmento A, Maritza, 42 años)

\begin{tabular}{|c|c|}
\hline Clase & Ficha Filtro \\
\hline $\begin{array}{l}\text { intas } \\
\text { rales }\end{array}$ & $\begin{array}{l}\text { Trabaja en la empresa HDC desde hace } 4 \text { meses, en el área de tele } \\
\text { marketing. Además, cuenta con experiencia en otro centro de contacto } \\
\text { como el de Corporación Saga Falabella, en el cual estuvo } 3 \text { años como } \\
\text { asesora telefónica. Dejó de trabajar por mejora salarial y se incorporó al } \\
\text { BCP, empresa con mayores beneficios, luego el BCP tercerizó sus } \\
\text { servicios y el sueldo ya no era el mismo y renunció para trabajar en HDC. } \\
\text { Bachiller en Ciencias de la Comunicación y Psicología, por motivos de } \\
\text { salud no pudo ejercer su carrera. Por ello, buscó nuevas opciones de } \\
\text { trabajo y decidió quedarse en un centro de contacto, ya que es un trabajo } \\
\text { donde puede trabajar sentada por un tema de salud; le ha ido muy bien y } \\
\text { hasta la fecha está trabajando en el sector. }\end{array}$ \\
\hline $\begin{array}{l}\text { Pre } \\
\text { sob } \\
\text { fun } \\
\text { di: }\end{array}$ & $\begin{array}{l}\text { Actualmente, tiene un horario establecido en el turno mañana, de lunes a } \\
\text { sábado de 09:00am a 04:00pm con media hora de break, le brindan } \\
\text { facilidades de horario por un tema de cierre de ventas, puede cambiar de } \\
\text { 03:00pm a 09:00pm. } \\
\text { Su primer contrato fue de } 2 \text { meses como periodo de prueba, luego renovó } \\
\text { contrato cada } 3 \text { meses. Su básico es de } S / 850.00 \text {, su variable tiene escala } \\
\text { y es de acuerdo a las ventas cerradas que establece la empresa. El } \\
\text { promedio del sueldo variable es de } S / 200.00 \text { al mes. Tiene un bono por } \\
\text { puntualidad de } S / 100.00 \text { al mes. Lo que significa que al mes gana un } \\
\text { promedio de } S / 1,150.00 \text {. }\end{array}$ \\
\hline $\begin{array}{l}\text { Experiencia } \\
\text { sobre el sector } \\
\text { de servicios }\end{array}$ & $\begin{array}{l}\text { La entrevistada cuenta con más de } 10 \text { años trabajando en el rubro de } \\
\text { Centros de Contacto en Lima Metropolitana. } \\
\text { El motivo principal de renuncia según su experiencia, es que la mayoría } \\
\text { de los jóvenes no se adaptan rápidamente a la labor en un Centro de } \\
\text { Contacto. Por ello, no venden los productos o servicios ofrecidos, además } \\
\text { no muestran interés por el trabajo y se conforman con la remuneración } \\
\text { básica, por lo cual la empresa no les renueva su contrato. } \\
\text { El tiempo de permanencia de los asesores telefónicos es de tres meses. }\end{array}$ \\
\hline $\begin{array}{c}\text { Información } \\
\text { Adicional }\end{array}$ & $\begin{array}{l}\text { La entrevistada indica que el horario le permite tener actividades } \\
\text { paralelas, no tiene hijos, pero aprovecha para estar más tiempo con su } \\
\text { familia. } \\
\text { En otros Centros de Contacto trabajan más de } 8 \text { horas y se estresan. } \\
\text { Algunos asesores telefónicos renuncian desde que se encuentran en el } \\
\text { periodo de capacitación. }\end{array}$ \\
\hline
\end{tabular}


Tabla 6. Observaciones de la entrevista (Segmento A, Kevin, 26 años)

\begin{tabular}{|c|c|}
\hline $\begin{array}{c}\text { Contexto } \\
\text { /Segmento }\end{array}$ & Asesor Telefónico \\
\hline $\begin{array}{l}\text { Observaciones } \\
\text { antes de la } \\
\text { entrevista }\end{array}$ & $\begin{array}{l}\text { La entrevista se coordinó previa comunicación con la gerente de } \\
\text { RRHH, quien asignó a un asesor telefónico del Centro de Contacto } \\
\text { HDC BPO Service. A solicitud del entrevistado se programó para el } \\
\text { día } 21 \text { de noviembre a las } 08: 10 \mathrm{pm} \text { en la Cafetería Rauletti, ubicada } \\
\text { en el distrito de Breña. El entrevistado se presentó en el horario } \\
\text { pactado. }\end{array}$ \\
\hline $\begin{array}{l}\text { Observaciones } \\
\text { durante la } \\
\text { entrevista }\end{array}$ & $\begin{array}{l}\text { La entrevista se realizó en un ambiente cómodo. Durante la } \\
\text { entrevista se presentaron inconvenientes por el ingreso de personas } \\
\text { al lugar, ocasionando algunas interrupciones. El entrevistado } \\
\text { accedió a responder a todas las preguntas planteadas. Al iniciar la } \\
\text { entrevista se le notaba un poco nervioso, se observaron varios } \\
\text { movimientos de manos y a medida que transcurría la entrevista se le } \\
\text { observó tranquilo, interesado y brindó información relevante en el } \\
\text { tema tratado. }\end{array}$ \\
\hline $\begin{array}{l}\text { Observaciones } \\
\text { después de la } \\
\text { entrevista }\end{array}$ & $\begin{array}{l}\text { La duración de la entrevista fue de } 45 \text { minutos. Luego de culminada } \\
\text { la entrevista se le observó más relajado, tranquilo y conversó acerca } \\
\text { de sus experiencias laborales. }\end{array}$ \\
\hline $\begin{array}{l}\text { Conclusión } \\
\text { general de la } \\
\text { entrevista del } \\
\text { asesor telefónico }\end{array}$ & $\begin{array}{l}\text { El entrevistado refiere que los factores que podrían afectar la } \\
\text { rotación de asesores son los siguientes: } \\
\text { Los jóvenes entre } 18 \text { a } 20 \text { años toman como un pasatiempo el trabajo } \\
\text { en un Centro de Contacto, debido a que el puesto no requiere de } \\
\text { experiencia previa y no están acostumbrados a trabajar bajo presión. } \\
\text { Falta de tolerancia con el trato recibido por parte del cliente. } \\
\text { Constante búsqueda de nuevas oportunidades laborales. } \\
\text { Finalmente, el entrevistado se siente a gusto con su labor y considera } \\
\text { que en algún momento dejará la labor de asesor telefónico, para } \\
\text { dedicarse a lo que realmente ha estudiado su carrera en Marketing. }\end{array}$ \\
\hline
\end{tabular}


Tabla 7. Ficha entrevista (Segmento A, Kevin, 26 años)

\begin{tabular}{|c|c|}
\hline Clase & Ficha Filtro \\
\hline $\begin{array}{l}\text { Preguntas } \\
\text { generales }\end{array}$ & $\begin{array}{l}\text { Actualmente labora en el área de cobranzas (Campaña por el BBVA) } \\
\text { tiene } 3 \text { años y } 6 \text { meses de experiencia en el Centro de Contacto HDC } \\
\text { BPO Service. También trabajó un año y medio en GSS, el motivo } \\
\text { principal de su última renuncia fue por asuntos personales. Cuenta con } \\
\text { experiencia en atención al cliente de forma presencial en centros } \\
\text { comerciales. Eligió trabajar en un Centro de Contacto porque su principal } \\
\text { objetivo era ganar experiencia en ventas, puesto que contaba con estudios } \\
\text { previos de marketing. }\end{array}$ \\
\hline $\begin{array}{l}\text { Preguntas } \\
\text { sobre sus } \\
\text { funciones } \\
\text { diarias }\end{array}$ & $\begin{array}{l}\text { El sistema de llamadas es "Predictivo" monitoreado por el supervisor, } \\
\text { quien asigna la cartera de clientes para cada asesor telefónico, se concreta } \\
\text { de } 25 \text { a } 30 \text { llamadas por hora. } \\
\text { Los horarios son rotativos semanalmente. Su horario actual de } 8: 00 \text { am a } \\
\text { 5:00 pm. y 10:00 am a 8:00 pm aplicados en los días de lunes a viernes y } \\
\text { los sábados de 9:00 am a 1:00 pm.(opcional) } 8 \text { horas diarias, incluido } 1 \\
\text { hora de refrigerio y } 20 \text { minutos de break, los cuales varían con frecuencia } \\
\text { de acuerdo con la campaña, Estas modificaciones son comunicadas desde } \\
\text { el inicio de la contratación y son establecidas en el contrato de trabajo, } \\
\text { indica que sus horarios le permiten llevar actividades paralelas como el } \\
\text { estudio. } \\
\text { Los contratos de trabajo, son temporales y se renuevan cada } 3 \text { meses. } \\
\text { La política de remuneración está conformada por un sueldo base de } \\
\text { S/850.00, más una variable (comisiones) entre } S / 450.00 \text { a S/500.00 como } \\
\text { tope aproximado, adicional tienen incentivos (no monetarios), como son } \\
\text { los vales de consumo por llegar a las metas u objetivos como equipo, } \\
\text { además de los beneficios educativos. El sueldo promedio mensual de un } \\
\text { asesor telefónico es de } S / 1,400.00 \text {. El sueldo percibido no está acorde con } \\
\text { el mercado, puesto que considera que la gestión que se realiza en cada } \\
\text { campaña, es alta, la remuneración mínima vital es baja y en su mayoría } \\
\text { no permite cubrir las necesidades básicas. }\end{array}$ \\
\hline $\begin{array}{l}\text { Experiencia } \\
\text { sobre el sector } \\
\text { de servicios }\end{array}$ & $\begin{array}{l}\text { En su campaña actual ha habido un ingreso mínimo de personal nuevo. } \\
\text { Si bien es cierto, existen periodos donde es necesario desvincular a } \\
\text { asesores telefónicos o reubicarlos en otras áreas, debido a la culminación } \\
\text { del contrato con la empresa usuaria. El periodo de capacitación depende } \\
\text { de la campaña. Los asesores no se sienten satisfechos con la campaña, es } \\
\text { decir no se adaptan con facilidad a la labor, trabajan bajo presión, no } \\
\text { alcanzan los indicadores, por lo tanto, no llegan a comisionar. } \\
\text { El tiempo de permanencia de un asesor es de } 6 \text { meses, considera que las } \\
\text { renuncias se dan entre jóvenes de } 18 \text { a } 20 \text { años. El motivo principal de }\end{array}$ \\
\hline
\end{tabular}




\begin{tabular}{|l|l|} 
& $\begin{array}{l}\text { permanecer en el Centro de Contacto se debe a que se presentan } \\
\text { oportunidades para seguir una línea de carrera como formador, analista } \\
\text { de calidad, capacitador, pero debido a la falta de tiempo no ha concluido } \\
\text { con la evaluación. }\end{array}$ \\
\hline $\begin{array}{l}\text { Información } \\
\text { Adicional }\end{array}$ & $\begin{array}{l}\text { Falta de información sobre la modalidad de contratos indeterminados. El } \\
\text { entrevistado nos indicó que hay poca cantidad de asesores telefónicos que } \\
\text { cuentan con más de un año laborando en el centro de contacto. }\end{array}$ \\
\hline
\end{tabular}


Tabla 8. Observaciones de la entrevista (Segmento A, María, 27 años)

\begin{tabular}{|c|l|}
\hline $\begin{array}{c}\text { Contexto } \\
\text { /Segmento }\end{array}$ & \multicolumn{1}{c|}{ Asesor Telefónico } \\
\hline $\begin{array}{c}\text { Observaciones } \\
\text { antes de la } \\
\text { entrevista }\end{array}$ & $\begin{array}{l}\text { La entrevista se coordinó gracias a contactos referenciales, se } \\
\text { concretó el domingo 26 de noviembre del 2017 a la 01:00pm en la } \\
\text { cafetería Roma, ubicada en el distrito de Magdalena. } \\
\text { Se presentaron atrasos en la llegada por parte del asesor telefónico. } \\
\text { La entrevista se inició a las 02:00 pm. }\end{array}$ \\
\hline $\begin{array}{c}\text { Observaciones } \\
\text { durante la } \\
\text { entrevista }\end{array}$ & $\begin{array}{l}\text { La entrevistada estaba un poco nerviosa, se cubría las manos, se } \\
\text { notaba una persona cerrada porque tenía los brazos cruzados, luego } \\
\text { empezó a relajarse, utilizaba sus manos para expresarse, se } \\
\text { agarraba mucho el pasador de la polera que tenía puesta, miraba a } \\
\text { los ojos al responder las pregu-ntas y luego bajaba la mirada y se } \\
\text { concentraba en su celular. }\end{array}$ \\
\hline $\begin{array}{c}\text { Observaciones } \\
\text { después de la } \\
\text { entrevista }\end{array}$ & $\begin{array}{l}\text { La entrevistada brindó información muy importante, además nos } \\
\text { recomendó a su supervisor para concretar una entrevista, le gustó } \\
\text { participar en la entrevista de profundidad, le pareció muy } \\
\text { interesante el tema de investigación. } \\
\text { La entrevista tuvo una duración de 40 minutos. }\end{array}$ \\
$\begin{array}{c}\text { Conclusión } \\
\text { general de la } \\
\text { entrevista del }\end{array}$ & $\begin{array}{l}\text { La entrevistada indica que la mayor rotación se da en los jóvenes } \\
\text { de 18 a 21 años. } \\
\text { Los asesores esperan las gratificaciones de julio y diciembre para } \\
\text { luego renunciar. } \\
\text { ventas y el trato que reciben del cliente no es el esperado. } \\
\text { En comparación con su trabajo anterior, las ventas por teléfono son } \\
\text { más difíciles que las ventas presenciales. Sus ingresos eran } \\
\text { mayores, pero por motivos personales ingresó al sector de los } \\
\text { Centros de Contacto para probar su desenvolvimiento y hacer línea } \\
\text { de carrera, trabajando 6 horas efectivas diarias. }\end{array}$ \\
\hline
\end{tabular}


Tabla 9. Ficha entrevista (Segmento A, María, 27 años)

\begin{tabular}{|c|c|}
\hline Clase & Ficha Filtro \\
\hline $\begin{array}{c}\text { Preguntas } \\
\text { generales }\end{array}$ & $\begin{array}{l}\text { Trabaja en Servicios Call Center del Perú SCC, en el área de ventas de } \\
\text { Portabilidad ENTEL. Es su primera experiencia en el sector de centro de } \\
\text { contacto, tiene un año y } 6 \text { meses. Además, cuenta con experiencia en } \\
\text { bancos y supermercados. Su trabajo anterior fue en el banco Interbank, } \\
\text { trabajó en el área de atención al cliente y ventas, renunció por temas } \\
\text { personales y familiares. En Interbank trabajaba de } 08: 30 \text { am a 07:00pm de } \\
\text { lunes a viernes y sábados de 09:00 am a 01:00pm, indica muchas horas de } \\
\text { trabajo y poco tiempo para estar con su hijo. } \\
\text { En SCC, el perfil del asesor que solicitan son jóvenes desde los } 18 \text { años } \\
\text { hasta los } 60 \text { años, sin experiencia previa, secundaria completa. }\end{array}$ \\
\hline $\begin{array}{c}\text { Preguntas } \\
\text { sobre sus } \\
\text { funciones } \\
\text { diarias }\end{array}$ & $\begin{array}{l}\text { Su horario laboral es de } 6 \text { horas efectivas diarias, tiene media hora de } \\
\text { break, de lunes a viernes de } 09: 00 \text { am a } 3: 30 \mathrm{pm} \text {, los sábados de } 09: 00 \text { a } \\
\text { 03:00pm, el segundo horario establecido por la empresa es de } 03: 30 \mathrm{pm} \text { a } \\
\text { 10:00pm, indica que si una es estudiante, le otorgan facilidades para } \\
\text { escoger el horario, los cambios de horarios se dan previa información al } \\
\text { asesor telefónico. El periodo de capacitación es de una semana } \\
\text { aproximadamente para esa campaña. } \\
\text { Su contrato inicial fue por un periodo de } 3 \text { meses, luego la renovación es } \\
\text { de } 2 \text { a } 3 \text { meses, dependiendo de los resultados obtenidos. En el contrato se } \\
\text { establece su horario de trabajo, los contratos indeterminados se aplican a } \\
\text { partir de los } 2 \text { años de permanencia y están sujetos a una evaluación de los } \\
\text { indicadores. } \\
\text { Los asesores telefónicos se clasifican por masters, los que siempre venden, } \\
\text { los medios son los que venden un poco menos que los masters, y el junior } \\
\text { es el personal que recién entra a trabajar. } \\
\text { El supervisor actualiza en su sistema un programa y lo comparte con los } \\
\text { asesores telefónicos para que les den seguimiento a sus ventas. } \\
\text { Su sueldo básico es de } S / 850.00 \text {, para comisionar establecen un rango de } \\
\text { ventas mensuales. El sueldo variable es de } \mathrm{S} / 1,300.00 \text { hasta } \mathrm{S} / 1,600.00 \\
\text { Brindan incentivos por puntualidad y asistencia el bono es de } \mathrm{S} / 200.00 \mathrm{El} \\
\text { sueldo promedio es de } \mathrm{S} / 2,500.00 \text { aproximadamente. Mientras que su } \\
\text { sueldo básico en Interbank era de } \mathrm{S} / 1,200.00 \text {, y su variable } \mathrm{S} / 1,500.00 \text { a } \\
\mathrm{S} / 2,000.0 \text {, en promedio de sueldo mensual era de } \mathrm{S} / 3,000.00 \text { trabajando } \\
\text { más horas. } \\
\text { En la empresa está permitido que el asesor telefónico pueda hacer doble } \\
\text { turno, como máximo dos a tres veces al mes para llegar a su meta y } \\
\text { aprovechar la buena base de datos de clientes (es opcional). }\end{array}$ \\
\hline
\end{tabular}




\begin{tabular}{|c|l|}
$\begin{array}{c}\text { Experiencia } \\
\text { sobre el } \\
\text { sector de } \\
\text { servicios }\end{array}$ & $\begin{array}{l}\text { La rotación de los asesores telefónicos es constante, su tiempo de } \\
\text { permanencia es entre } 3 \text { a } 6 \text { meses, la edad es de } 18 \text { a } 21 \text { años sin carga } \\
\text { familiar. La presión por las ventas, no les permite llegar a su meta y por lo } \\
\text { tanto, no les renuevan su contrato, del total de } 25 \text { que ingresaron de su } \\
\text { grupo quedaron dos. } \\
\text { En su área indica que de los } 500 \text { asesores telefónicos, solo } 100 \text { o 150 } \\
\text { aproximadamente tienen más de un año. }\end{array}$ \\
\hline $\begin{array}{c}\text { Información } \\
\text { Adicional }\end{array}$ & $\begin{array}{l}\text { Considera que trabajar menos horas en un Centro de Contacto es favorable } \\
\text { porque le permite tener más tiempo para estar con la familia, estudiar y el } \\
\text { básico está acorde porque trabaja solo } 6 \text { horas. } \\
\text { Después de } 6 \text { meses se puede ascender a supervisor, si se da una línea de } \\
\text { carrera, hay convocatorias internas para otros puestos en las diversas áreas. } \\
\text { La comunicación en el Centro de Contacto es horizontal y todos se tratan } \\
\text { con respeto. } \\
\text { La capacitación es corta, dura } 10 \text { días aproximadamente, según la campaña } \\
\text { y requerimiento del cliente. }\end{array}$ \\
\hline
\end{tabular}


Tabla 10. Observaciones de la entrevista (Segmento A, María, 27 años)

\begin{tabular}{|c|c|}
\hline $\begin{array}{l}\text { Contexto } \\
\text { /Segmento }\end{array}$ & Asesor Telefónico \\
\hline $\begin{array}{l}\text { Observaciones } \\
\text { antes de la } \\
\text { entrevista }\end{array}$ & $\begin{array}{l}\text { La entrevista se concretó para el jueves } 30 \text { de noviembre } 2017 \text { a las } \\
\text { 07:00pm en las mismas instalaciones de la empresa, ubicada en el } \\
\text { distrito de La Victoria. } \\
\text { A la hora indicada empezó la entrevista, el lugar era muy cómodo, } \\
\text { agradable porque no había ruido, la oficina contaba con un } \\
\text { escritorio, una computadora, sillas ergonómicas, aire } \\
\text { acondicionado, buena iluminación. }\end{array}$ \\
\hline $\begin{array}{l}\text { Observaciones } \\
\text { durante la } \\
\text { entrevista }\end{array}$ & $\begin{array}{l}\text { Al inicio de la entrevista, la asesora telefónica se notaba un poco } \\
\text { nerviosa porque no le gustan las cámaras, al comienzo no quería } \\
\text { ser grabada ni filmada, pero se le explicó por qué se requería y } \\
\text { aceptó. } \\
\text { Durante la entrevista movía mucho sus manos, jugaba con el } \\
\text { lapicero y no quería mirar a la cámara, después entró en confianza } \\
\text { y estuvo más tranquila durante el resto de la entrevista. }\end{array}$ \\
\hline $\begin{array}{l}\text { Observaciones } \\
\text { después de la } \\
\text { entrevista }\end{array}$ & $\begin{array}{l}\text { Brindó información importante para el tema de investigación en } \\
\text { relación con los factores en estudio. Recomendó ir a más empresas } \\
\text { del sector para continuar entrevistando, ya que le pareció muy } \\
\text { interesante y relevante la rotación de los asesores telefónicos. } \\
\text { La entrevista duró } 20 \text { minutos. }\end{array}$ \\
\hline $\begin{array}{c}\text { Conclusión } \\
\text { general de la } \\
\text { entrevista del } \\
\text { asesor telefónico }\end{array}$ & $\begin{array}{l}\text { La entrevistada informa que la mayor rotación de asesores } \\
\text { telefónicos se debe a la falta de conocimiento de los servicios que } \\
\text { ofrecen, el periodo de capacitación es muy corto y no se sienten } \\
\text { preparados para atender a los clientes. }\end{array}$ \\
\hline
\end{tabular}


Tabla 11. Ficha de la entrevista (Segmento A, María, 27 años)

\begin{tabular}{|c|c|}
\hline $\begin{array}{l}\text { Contexto } \\
\text { /Segmento }\end{array}$ & Ficha Filtro \\
\hline $\begin{array}{l}\text { Preguntas } \\
\text { generales }\end{array}$ & $\begin{array}{l}\text { María tiene } 27 \text { años, trabaja para MTG PERÚ SAC en el área de } \\
\text { cobranzas, tiene más de un año trabajando en el área. } \\
\text { Anteriormente trabajó para el Centro de Contacto Tele Gestión } \\
\text { Empresarial SAC, renunció por mejoras económicas laborales, } \\
\text { permaneció solo } 8 \text { meses. }\end{array}$ \\
\hline $\begin{array}{l}\text { Peguntas sobre } \\
\text { sus funciones } \\
\quad \text { diarias }\end{array}$ & $\begin{array}{l}\text { Tiene un horario rotativo, actualmente su jornada establecida es de } \\
\text { lunes a viernes de } 09: 00 \text { am a } 06: 00 \mathrm{pm} \text { y los sábados, de 08:00am } \\
\text { a } 01: 00 \mathrm{pm} \text {, pero ese horario puede variar. Cuando hay un cambio, } \\
\text { le informan un día antes y tiene que adaptarse, pero cuando tiene } \\
\text { clases le dan facilidades al momento del horario de salida. } \\
\text { Su modalidad de contrato es a plazo fijo y cada } 3 \text { meses renuevan } \\
\text { su contrato, previamente hay una evaluación de resultados. } \\
\text { El sueldo promedio de un asesor telefónico es de } \mathrm{S} / 1,400.00 \text {, tiene } \\
\text { un sueldo base de } \mathrm{S} / 1,000.00 \text { y el sueldo variable oscila entre } \\
\mathrm{S} / 300.00 \text { y } \mathrm{S} / 400.00 \text { como máximo. }\end{array}$ \\
\hline $\begin{array}{l}\text { Experiencia sobre } \\
\text { el sector de } \\
\text { servicio }\end{array}$ & $\begin{array}{l}\text { Tiene trabajando en el sector más de un año y ocho meses, se } \\
\text { cambió de trabajo por mejora salarial y mejores horarios que le } \\
\text { permiten seguir estudiando. Considera que el sueldo promedio está } \\
\text { acorde al mercado, ya que puede cubrir sus necesidades básicas. }\end{array}$ \\
\hline $\begin{array}{l}\text { Información } \\
\text { adicional }\end{array}$ & $\begin{array}{l}\text { Indica que el factor que afecta la rotación de asesores telefónicos } \\
\text { es la falta de interés en el puesto, debido a que la mayoría son } \\
\text { jóvenes de } 18 \text { a } 22 \text { años que no llegan a sus metas, se aburren y } \\
\text { renuncian al mes: incluso algunos asesores telefónicos abandonan } \\
\text { el trabajo terminando la capacitación. }\end{array}$ \\
\hline
\end{tabular}


Tabla 12. Observaciones de la entrevista (Segmento B, Frank, 30 años)

\begin{tabular}{|c|l|}
\hline $\begin{array}{c}\text { Contexto } \\
\text { /Segmento }\end{array}$ & \multicolumn{1}{|c|}{ Asesor Telefónico } \\
\hline $\begin{array}{c}\text { Observaciones } \\
\text { antes de la } \\
\text { entrevista }\end{array}$ & $\begin{array}{l}\text { La entrevista fue coordinada según la recomendación de la } \\
\text { supervisora del centro de contacto del Banco Interbank, para el } \\
\text { martes 28 de noviembre a las 7.00pm, de acuerdo con la } \\
\text { disponibilidad del asesor, la entrevista se realizó en la Cafetería } \\
\text { ubicado en el Jr. Ucayali- Cercado de Lima. }\end{array}$ \\
\hline $\begin{array}{c}\text { Observaciones } \\
\text { durante la } \\
\text { entrevista }\end{array}$ & $\begin{array}{l}\text { El entrevistado estaba un poco nervioso debido a la filmación, luego } \\
\text { entró en confianza a medida que transcurría la entrevista. Nos } \\
\text { comentó acerca de su experiencia laboral en el sector y sobre su } \\
\text { experiencia en trabajo de campo, realizando comparaciones con su } \\
\text { trabajo actual. }\end{array}$ \\
\hline $\begin{array}{c}\text { Observaciones } \\
\text { después de la } \\
\text { entrevista }\end{array}$ & $\begin{array}{l}\text { La entrevista tuvo una duración de 25 minutos. Se le notaba apurado, } \\
\text { puesto que tenía otras actividades programadas, respondió a todas } \\
\text { las preguntas de investigación, información relevante que permite } \\
\text { realizar comparaciones del trabajo de un centro de contacto } \\
\text { tercerizado y centro de contacto propio. }\end{array}$ \\
\hline $\begin{array}{c}\text { Conclusión } \\
\text { general de la } \\
\text { entrevista del } \\
\text { asesor telefónico }\end{array}$ & $\begin{array}{l}\text { Indica que la rotación es mínima en el Centro de Contacto del banco } \\
\text { Interbank, con el grupo de trabajo que empezó desde hace dos años } \\
\text { se ha mantenido hasta la fecha, sólo renunciaron 3 asesores } \\
\text { telefónicos por motivos de baja productividad. } \\
\text { Con respecto a las variables de investigación en este tipo de centro } \\
\text { de contacto, el sueldo promedio es mayor, el horario de trabajo es } \\
\text { fijo de 45 horas semanales, los contratos son renovados cada 6 meses } \\
\text { según la productividad, luego de 2 años pueden suscribir contrato } \\
\text { indeterminado previa evaluación de resultados. }\end{array}$ \\
\hline
\end{tabular}


Tabla 13. Ficha de la entrevista (Segmento B, Frank, 30 años)

\begin{tabular}{|c|c|}
\hline $\begin{array}{l}\text { Contexto } \\
\text { /Segmento }\end{array}$ & Ficha filtro \\
\hline $\begin{array}{l}\text { Preguntas } \\
\text { generales }\end{array}$ & $\begin{array}{l}\text { Frank tiene } 30 \text { años, trabaja para el área de Tele marketing, se dedica } \\
\text { a las ventas de tarjeta de crédito. Tiene } 2 \text { años trabajando en el centro } \\
\text { de contacto de Interbank. Cuenta con experiencia en el sector, } \\
\text { anteriormente trabajó para el centro de contacto Luz del Sur en el área } \\
\text { de reclamos, realizó sus prácticas profesionales, renunció por motivos } \\
\text { laborales, crecimiento personal y económico, además ha trabajado de } \\
\text { forma presencial en ventas como corredor de seguro en la empresa } \\
\text { Rímac Seguros. }\end{array}$ \\
\hline $\begin{array}{l}\text { Preguntas sobre } \\
\text { sus funciones } \\
\text { diarias }\end{array}$ & $\begin{array}{l}\text { Su horario laboral es de lunes a viernes de } 09: 00 \text { am a } 06: 00 \mathrm{pm} \text { y los } \\
\text { sábados de 09:00am de } 02: 00 \mathrm{pm} \text {. (opcional) } \\
\mathrm{Su} \text { sueldo promedio es de } \mathrm{S} / 2,500.00 \text { a } \mathrm{S} / 3,000.00 \text {, conformado por } \\
\text { el básico } \mathrm{S} / 750.00 \text { y el variable que oscila entre } \mathrm{S} / 1,500.00 \text { a } \\
\mathrm{S} / 2,000.00 \text {, para que puedan comisionar deben cumplir el } 100 \% \text { de } \\
\text { sus indicadores. } \\
\text { El primer contrato es de } 3 \text { meses, luego } 6 \text { meses y, después de } 2 \text { años } \\
\text { son contratos indeterminados, previa evaluación de resultados. Hay } \\
\text { una cláusula que indica que el contrato de renovación está sujeto a la } \\
\text { productividad y el horario puede variar. }\end{array}$ \\
\hline $\begin{array}{l}\text { Experiencia } \\
\text { sobre el sector de } \\
\quad \text { servicios }\end{array}$ & $\begin{array}{l}\text { Tiene más de } 10 \text { años trabajando en el sector, tiene experiencia en } \\
\text { atención al cliente y ventas. En comparación con el sueldo promedio } \\
\text { que percibía en el centro de contacto de Luz del Sur fono cliente era } \\
\text { un básico de } \mathrm{S} / 1,500.00 \text {. } \\
\text { Actualmente, no está conforme con el sueldo base que establece } \\
\text { como política el Banco Interbank, debería estar en un básico de } \\
\mathrm{S} / 1,000.00 \text {; ya que si no llega al } 100 \% \text { de sus indicadores no podría } \\
\text { comisionar y todo su esfuerzo trabajado en el mes sería en vano. }\end{array}$ \\
\hline $\begin{array}{c}\text { Información } \\
\text { Adicional }\end{array}$ & $\begin{array}{l}\text { Refiere que los factores que afectan la rotación en la mayoría de los } \\
\text { asesores telefónicos, se debe a que se frustran por no llegar a la meta } \\
\text { de ventas y no toleran el trabajo bajo presión. }\end{array}$ \\
\hline
\end{tabular}


Tabla 14. Observaciones de la entrevista (Segmento B, Naya, 32 años)

\begin{tabular}{|c|l|}
\hline $\begin{array}{c}\text { Contexto } \\
\text { /Segmento }\end{array}$ & \multicolumn{1}{c|}{ Asesor Telefónico } \\
\hline $\begin{array}{c}\text { Observaciones } \\
\text { antes de la } \\
\text { entrevista }\end{array}$ & $\begin{array}{l}\text { La entrevista se realizó el día 01 de diciembre 2017 a las 03:00 pm en } \\
\text { las instalaciones del BCP ubicado en Jr. Lampa 499 Cercado de Lima. } \\
\text { La entrevista se inició en el horario pactado. }\end{array}$ \\
\hline $\begin{array}{c}\text { Observaciones } \\
\text { durante la } \\
\text { entrevista }\end{array}$ & $\begin{array}{l}\text { El lugar era cómodo, un ambiente tranquilo. La entrevistada presentó } \\
\text { conviosismo en todo el tiempo de la entrevista, debido a que jugaba } \\
\text { indicó que no le gustan las cámaras, pese a ello, respondió todas las } \\
\text { preguntas planteadas. }\end{array}$ \\
\hline $\begin{array}{c}\text { Observaciones } \\
\text { después de la } \\
\text { entrevista }\end{array}$ & $\begin{array}{l}\text { La información obtenida muy relevante para el tema de investigación, } \\
\text { las variables de estudio se pueden comparar con otros Centros de } \\
\text { Contacto, sus respuestas fueron claras y específicas. }\end{array}$ \\
\hline $\begin{array}{c}\text { Conclusión } \\
\text { general de la } \\
\text { entrevista del } \\
\text { asesor } \\
\text { telefónico }\end{array}$ & $\begin{array}{l}\text { El índice de rotación en este Centro de Contacto es mínimo, ya que el } \\
\text { personal es permanente, la mayoría tiene más de un año en las } \\
\text { diferentes áreas que pertenecen al Centro de Contacto. }\end{array}$ \\
\hline
\end{tabular}


Tabla 15. Ficha de la entrevista (Segmento B, Naya, 32 años)

\begin{tabular}{|c|c|}
\hline $\begin{array}{c}\text { Contexto } \\
\text { /Segmento }\end{array}$ & Ficha Filtro \\
\hline $\begin{array}{c}\text { Preguntas } \\
\text { generales }\end{array}$ & $\begin{array}{l}\text { Naya tiene } 32 \text { años, trabaja en el BCP desde hace } 10 \text { años y } 3 \text { meses, } \\
\text { actualmente su puesto es funcionaria de Bec en Contacto, ha tenido una } \\
\text { línea de carrera en el banco, empezó como un asesor de consultas } \\
\text { generales con un sueldo mínimo sin comisiones. Trabajó anteriormente } \\
\text { en un centro de contacto en telefonía de larga distancia. } \\
\text { Perfil de un asesor: Estudiantes con carreras universitarias por culminar, } \\
\text { disponibles a tiempo completo. }\end{array}$ \\
\hline $\begin{array}{l}\text { Preguntas } \\
\text { sobre sus } \\
\text { funciones } \\
\text { diarias }\end{array}$ & $\begin{array}{l}\text { Hay distintos horarios, pero en su área existen dos horarios fijos } \\
\text { establecidos: lunes a viernes de 09:00am a } 06: 00 \mathrm{pm} \text { y los sábados de } \\
09: 00 \mathrm{am} \text { a } 02: 00 \mathrm{pm} \text { y de lunes a viernes de } 10: 00 \mathrm{am} \text { a } 08: 00 \mathrm{pm} \text {. } \\
\text { Los contratos dependen del puesto, si son bachilleres contrato } \\
\text { indeterminado, si son estudiantes a plazo fijo, se renuevan cada } 6 \text { meses. } \\
\text { Por política de la empresa para tener contrato indeterminado tiene que } \\
\text { tener } 3 \text { años y está sujeto a una evaluación de desempeño. } \\
\text { La política remunerativa está establecida por códigos, anteriormente el } \\
\text { sueldo base era para todos } \mathrm{S} / 800.00 \text {, y no existía comisiones, posterior a } \\
\text { ello implementaron las ventas y el tope era de } \mathrm{S} / 2,500.00 \text { actualmente en } \\
\text { su puesto el sueldo promedio del asesor es de } \mathrm{S} / 3,700.00 \text { en su área, con } \\
\text { un sueldo base de } \mathrm{S} / 3,000.00 \text {. } \\
\text { El sueldo base indica que está acorde a lo que el puesto requiere, el bono } \\
\text { le parece que debería ser más elevado porque para alcanzar los } \\
\text { indicadores hay un esfuerzo adicional por el cumplimiento de ventas. }\end{array}$ \\
\hline $\begin{array}{l}\text { Experiencia } \\
\text { sobre el sector } \\
\text { de servicios }\end{array}$ & $\begin{array}{l}\text { En su experiencia con más de } 10 \text { años, indica que la rotación se daba hace } \\
4 \text { a } 5 \text { años atrás, ya que en los puestos actuales se encuentra las personas } \\
\text { más antiguas y el personal nuevo ha sido contratado desde hace un año y } \\
8 \text { meses. } \\
\text { La rotación era mayor porque los asesores telefónicos no se adaptaban a } \\
\text { los horarios, no daban permisos para ninguna ocasión, cierre de } \\
\text { contratos, no había renovaciones, descansos médicos falsificados. Los } \\
\text { principales motivos de renuncias se daban por el horario rotativo y el } \\
\text { sueldo. Actualmente en su área no existe rotación. El tiempo de } \\
\text { permanencia es de } 2 \text { años. }\end{array}$ \\
\hline
\end{tabular}


El clima laboral anteriormente no se percibía, los ascensos eran difíciles

Información Adicional porque no había una buena comunicación con los jefes directos, sólo ascendían los que se recomendaban entre los jefes. Actualmente el banco está presentando cambios con respecto al clima laboral, por los mismos puestos nuevos que están creando. Para postular internamente a otra área se debe tener un año como mínimo en la empresa. 
Tabla 16. Observaciones de la entrevista (Segmento C, Supervisor)

\begin{tabular}{|c|l|}
\hline $\begin{array}{c}\text { Contexto } \\
\text { /Segmento }\end{array}$ & \multicolumn{1}{|c|}{ Supervisor } \\
\hline $\begin{array}{c}\text { Observaciones } \\
\text { antes de la } \\
\text { entrevista }\end{array}$ & $\begin{array}{l}\text { La entrevista se coordinó vía telefónica. Se dio lugar el día 23 de } \\
\text { noviembre, en la sala de recepción del Banco Interbank ubicado } \\
\text { en el Centro Cívico, a las 11:30 am. }\end{array}$ \\
\hline $\begin{array}{c}\text { Observaciones } \\
\text { durante la } \\
\text { entrevista }\end{array}$ & $\begin{array}{l}\text { La entrevista se realizó en un ambiente cómodo. La entrevistada } \\
\text { accedió a responder a todas las preguntas planteadas, se le notaba } \\
\text { muy interesada en el tema de investigación, mostraba seguridad } \\
\text { en sus palabras, sus respuestas fueron claras, contaba con amplios } \\
\text { conocimientos del área a su cargo. }\end{array}$ \\
\hline $\begin{array}{c}\text { Observaciones } \\
\text { después de la } \\
\text { entrevista }\end{array}$ & $\begin{array}{l}\text { La entrevista tuvo una duración de 30 minutos. A la entrevistada } \\
\text { se le observó tranquila, brindó información relevante en el tema } \\
\text { tratado. Las políticas contractuales, salariales y turnos } \\
\text { establecidos en el Banco Interbank son totalmente diferentes a los } \\
\text { centros de contacto que tercerizan sus servicios. El primer filtro } \\
\text { que utilizan para contratar asesores telefónicos es que sean } \\
\text { mayores de 20 años con responsabilidades o carga familiar, para } \\
\text { evitar rotación en el área. } \\
\text { Nos recomendó a uno de sus asesores telefónicos para concretar } \\
\text { una entrevista. }\end{array}$ \\
\hline $\begin{array}{c}\text { Conclusión general } \\
\text { de la entrevista del } \\
\text { supervisor }\end{array}$ & $\begin{array}{l}\text { Los asesores telefónicos tienen un horario flexible, el sueldo } \\
\text { promedio está acorde al mercado laboral, los contratos son cada 6 } \\
\text { meses, factores que permiten la permanencia en el centro de } \\
\text { contacto. La entrevistada indica que existe una baja rotación de } \\
\text { asesores telefónicos en su área, por lo tanto, los factores que } \\
\text { pueden afectar las salidas de los asesores telefónicos son: } \\
\text { Dejar de percibir su sueldo variable por la falta de cumplimiento } \\
\text { de sus metas. La baja productividad puede determinar que el } \\
\text { próximo año no permanezcan en el puesto. } \\
\text { Con esta entrevista se ha logrado realizar la comparación de los } \\
\text { asesores telefónicos que trabajan en un centro de contacto propio. }\end{array}$ \\
\hline
\end{tabular}


Tabla 17. Ficha de la entrevista (Segmento C, Supervisor)

\begin{tabular}{|c|c|}
\hline $\begin{array}{c}\text { Contexto } \\
\text { /Segmento }\end{array}$ & Ficha Filtro \\
\hline $\begin{array}{c}\text { Experiencia } \\
\text { en el sector de } \\
\text { Centro de } \\
\text { Contacto }\end{array}$ & $\begin{array}{l}\text { La entrevistada trabaja desde marzo } 2015 \text { para el Centro de Contacto de } \\
\text { Interbank. El perfil del asesor telefónico: edad entre } 20 \text { y } 30 \text { años, } \\
\text { estudiantes técnicos y/o universitarios, que tenga experiencia en ventas } \\
\text { telefónicas o presencial, con responsabilidades familiares y con } \\
\text { vocación de servicio, el requerimiento se basa en resultados obtenidos } \\
\text { en encuestas internas. El área es televentas: ventas de tarjeta de crédito, } \\
\text { pagos automáticos, seguros de tarjetas, un crosselling con una cartera de } \\
\text { clientes bancarizados y no bancarizados. }\end{array}$ \\
\hline $\begin{array}{c}\text { Información } \\
\text { de las } \\
\text { variables de } \\
\text { estudio }\end{array}$ & $\begin{array}{l}\text { Los turnos de trabajo son de ocho horas y media efectivas diarias fuera } \\
\text { del horario de refrigerio y break, de lunes a viernes de } 8: 00 \text { am a } 6: 00 \\
\text { pm. Existe sólo un horario establecido, no tienen part-time. Se suscriben } \\
\text { contratos por tres, seis meses y un año, evalúan condiciones de actitud } \\
\text { y de acuerdo a resultados se renuevan los contratos. Por política de la } \\
\text { empresa a partir del segundo año, se evalúa un contrato indeterminado. } \\
\text { El sueldo base es de } \mathrm{S} / 750.00 \text {, las comisiones son de acuerdo al logro } \\
\text { de metas al } 100 \% \text {, aproximadamente desde } \mathrm{S} / 1,000.00 \text { hasta } \mathrm{S} / 1,600.00 \text {, } \\
\text { además de los incentivos del área de calidad de } \mathrm{S} / 150.00 \text { a } \mathrm{S} / 250.00 \text {. En } \\
\text { promedio ganan entre } \mathrm{S} / 2,500.00 \text { a } \mathrm{S} / 3,000.00 \text {; como beneficios } \\
\text { adicionales tienen los viajes promocionales, para los mejores } \\
\text { vendedores de todo el año. }\end{array}$ \\
\hline $\begin{array}{l}\text { Factores que } \\
\text { afectan la } \\
\text { rotación de } \\
\text { asesores } \\
\text { telefónicos }\end{array}$ & $\begin{array}{l}\text { Este año } 2017 \text { no han tenido ingreso de personal nuevo en el área. Indica } \\
\text { que la rotación del año } 2016 \text { y } 2017 \text { ha sido muy baja, casi nada, el } \\
\text { porcentaje de renuncias del año } 2017 \text { está entre un } 2 \% \text { y } 3 \% \text {, del total } \\
\text { de } 119 \text { asesores telefónicos del área. Estas renuncias se debieron a un } \\
\text { cambio de gerencia, por necesidad tenían que reducir personal y sólo se } \\
\text { quedaron con } 13 \text { asesores telefónicos de los } 17 \text { del total de su equipo. } \\
\text { En el } 2016 \text { firmaron contrato } 60 \text { asesores telefónicos por tres meses, de } \\
\text { los cuales solo quedó el } 50 \% \text {, ya que es parte del proceso de evaluación } \\
\text { del periodo de prueba. } \\
\text { La permanencia de un asesor telefónico en su área es de dos años. }\end{array}$ \\
\hline $\begin{array}{c}\text { Información } \\
\text { Adicional }\end{array}$ & $\begin{array}{l}\text { De acuerdo a una encuesta interna de clima laboral, los asesores } \\
\text { telefónicos prefieren trabajar menos de } 8 \text { horas, ya que sienten mucha } \\
\text { carga laboral, por ello, se ha establecido trabajar } 6 \text { horas efectivas a } \\
\text { partir de enero } 2018 \text {. Hay un piloto donde los asesores trabajan } 6 \text { horas } \\
\text { con las mismas metas establecidas y obtienen excelentes resultados, con } \\
\text { este piloto se demuestra que trabajar menos horas podrá optimizar sus }\end{array}$ \\
\hline
\end{tabular}


tiempos y evitar el estrés laboral. Este tipo de trabajo requiere de asesores telefónicos que se adapten a los cambios.

Un asesor telefónico contento es más productivo y beneficioso para el centro de contacto. 
Tabla 18. Observaciones de la entrevista (Segmento C, Supervisor)

\begin{tabular}{|c|l|}
\hline $\begin{array}{c}\text { Contexto } \\
\text { /Segmento }\end{array}$ & \multicolumn{1}{|c|}{ Supervisor } \\
\hline $\begin{array}{c}\text { Observaciones } \\
\text { antes de la } \\
\text { entrevista }\end{array}$ & $\begin{array}{l}\text { La entrevista se coordinó vía telefónica. Se dio lugar el día 29 de } \\
\text { noviembre a las 06:00 pm., en las instalaciones del BCP, ubicado en } \\
\text { Jr. Lampa 499, Cercado de Lima. La entrevista se inició en el } \\
\text { horario pactado. }\end{array}$ \\
\hline $\begin{array}{c}\text { Observaciones } \\
\text { durante la } \\
\text { entrevista }\end{array}$ & $\begin{array}{l}\text { El entrevistado fue muy amable y mostró mucho interés en las } \\
\text { preguntas planteadas, cuenta con conocimientos amplios en el } \\
\text { sector, ya que lleva 9 años de experiencia. Además, ha sido muy } \\
\text { interesante el inicio de su labor, es decir la línea de carrera realizada } \\
\text { en el Banco. } \\
\text { Comentó de su experiencia laboral y brindó información relevante } \\
\text { para realizar un comparativo entre el Centro de Contacto propio del } \\
\text { BCP con los Centros de Contacto externos. } \\
\text { Se notaba tranquilo al responder a las preguntas de investigación. }\end{array}$ \\
$\begin{array}{c}\text { Conclusión } \\
\text { general de la } \\
\text { supervisor }\end{array}$ & $\begin{array}{l}\text { La entrevista tuvo una duración de 30 minutos. El entrevistado nos } \\
\text { comentó a detalle el tema de los indicadores de los asesores } \\
\text { telefónicos que están a su cargo. Asimismo, nos indicó que por } \\
\text { motivos de la labor realizada en los Centros de Contacto, los } \\
\text { asesores deberían mantener un tiempo de permanencia como } \\
\text { máximo 4 años, luego de ese tiempo el rendimiento o la } \\
\text { productividad no es al 100\%, lo recomendable es que puedan rotar } \\
\text { por otras líneas del banco. } \\
\text { No especificó monto de remuneración establecido en este Centro de } \\
\text { Contacto, solo confirmó que el sueldo es superior al promedio del } \\
\text { mercado. } \\
\text { después de la } \\
\text { entrevista }\end{array}$ \\
\hline $\begin{array}{l}\text { El sueldo promedio es mayor al del mercado laboral, los horarios } \\
\text { son fijos, los contratos se renuevan cada 6 meses, el banco motiva a } \\
\text { sus trabajadores para que terminen su carrera y puedan tener un } \\
\text { contrato indeterminado. }\end{array}$ \\
\hline
\end{tabular}


Tabla 19. Ficha de la entrevista (Segmento C, Supervisor)

\begin{tabular}{|c|c|}
\hline $\begin{array}{l}\text { Contexto } \\
\text { /Segmento }\end{array}$ & Ficha Filtro \\
\hline $\begin{array}{c}\text { Experienci } \\
\text { a en el } \\
\text { sector de } \\
\text { Centro de } \\
\text { Contacto }\end{array}$ & $\begin{array}{l}\text { Supervisor Inbound de Bec en contacto, Gerencia de Líneas Comerciales } \\
\text { del BCP, desde hace } 9 \text { años. Se inició en el área de sistemas y desde el } \\
2013 \text { ascendió como supervisor. Existe una organización vertical de } \\
\text { gerentes de división a gerentes de áreas. La comunicación de asesor a } \\
\text { supervisor es horizontal, es decir fluida. El perfil del asesor telefónico: alto } \\
\text { nivel de comunicación empática, autocontrol y actitud con clientes y pares. } \\
\text { Se requiere experiencia y estudios previos, con carreras universitarias } \\
\text { concluidas y en curso dependiendo de la línea de entrada. Tiene a su cargo } \\
\text { a } 15 \text { asesores en su mayoría son mujeres. }\end{array}$ \\
\hline $\begin{array}{c}\text { Informació } \\
\text { n de las } \\
\text { variables } \\
\text { de estudio }\end{array}$ & $\begin{array}{l}\text { El sistema de llamadas es personalizado con una cartera de clientes } \\
\text { asignada a cada asesor telefónico. } \\
\text { Los turnos de trabajo son: lunes a viernes 9:00 am a 6:00 pm., el segundo } \\
\text { horario de 10:00 am a 8:00 pm., sábados de 9:00am a 2:00 pm solo para el } \\
\text { primer turno, incluido horario de refrigerio y dos breaks de 15 min. } \\
\text { Sobre la modalidad de contratos: La contratación es fija o indeterminada } \\
\text { dependiendo del grado de estudios. La renovación es cada } 6 \text { meses. } \\
\text { Culminados los estudios pasan a contrato indeterminado, luego de dos años } \\
\text { y medio de permanencia en el Centro de Contacto. También existen } \\
\text { políticas internas: no estar reportado por la SBS y haber alcanzado sus } \\
\text { indicadores (meta de ventas, meta de satisfacción, meta de contacto con } \\
\text { clientes), producto y monitoreo de llamadas y se evalúa la meta de } \\
\text { desempeño anual. } \\
\text { Sobre la remuneración, conformado por el sueldo básico, una variable y } \\
\text { bono que se da en forma trimestral (los sueldos se establecen llegando } \\
\text { mínimo al } 80 \% \text { de sus indicadores), según el promedio del mercado hay } \\
\text { variación de sueldos según la función que realizan los diferentes asesores } \\
\text { telefónicos. }\end{array}$ \\
\hline $\begin{array}{l}\text { Factores } \\
\text { que afectan } \\
\text { la rotación } \\
\text { de asesores } \\
\text { telefónicos }\end{array}$ & $\begin{array}{l}\text { La evaluación y el filtro de selección es muy estricta, el personal está muy } \\
\text { preparado y el ingreso de personal nuevo es mínimo, en la mayoría de los } \\
\text { casos se integran otros colaboradores de otras áreas. En el último año se ha } \\
\text { presentado una alta rotación interna. El asesor que renuncia de manera } \\
\text { voluntaria, se va por otras oportunidades de empleo, desempeñándose en } \\
\text { otro tipo de funciones, no necesariamente en la misma labor. El tiempo de } \\
\text { permanencia es de } 4 \text { años. }\end{array}$ \\
\hline
\end{tabular}


Los asesores telefónicos contratados son universitarios en curso o estudios concluidos. Se exige que terminen su carrera universitaria para tener un contrato indeterminado. El principal motivo de renuncia de un asesor telefónico es por una mejora salarial, se pueden presentar para una convocatoria interna o externa dentro del banco.

Existen asesores telefónicos que cuentan con más de 6, 8, 10 años en el Centro de Contacto, solamente por evitar salir de su zona de confort. 
Tabla 20. Observaciones de la entrevista (Segmento C, Gerente)

\begin{tabular}{|c|l|}
\hline $\begin{array}{c}\text { Contexto } \\
\text { /Segmento }\end{array}$ & \multicolumn{1}{c|}{ Gerente de Recursos Humanos } \\
\hline $\begin{array}{c}\text { Observaciones } \\
\text { antes de la } \\
\text { entrevista }\end{array}$ & $\begin{array}{l}\text { La entrevista se concretó con el apoyo del Director General del Centro } \\
\text { de Contacto HDC BPO Service. } \\
\text { electrónicos, para el jueves 05 de octubre 2017 a las 08:00 am, en la } \\
\text { oficina ubicada en calle Chillón No 901 en el distrito de San Isidro. }\end{array}$ \\
\hline $\begin{array}{c}\text { Observaciones } \\
\text { durante la } \\
\text { entrevista }\end{array}$ & $\begin{array}{l}\text { La entrevistada nos recibió en su oficina, un lugar formal y cómodo. } \\
\text { La persona entrevistada accedió a responder a todas nuestras preguntas, } \\
\text { contaba con mucha predisposición, además nos brindó la información } \\
\text { necesaria sobre el índice de rotación de sus asesores telefónicos en su } \\
\text { Centro de Contacto HDC BPO Service; además, durante la entrevista } \\
\text { realizó algunas llamadas a la persona encargada de cada área a fin de } \\
\text { brindarnos una información más precisa. }\end{array}$ \\
\hline $\begin{array}{c}\text { Observaciones } \\
\text { después de la } \\
\text { entrevista }\end{array}$ & $\begin{array}{l}\text { Obtuvimos información importante referente a nuestro tema de } \\
\text { investigación sobre los asesores telefónicos. La entrevistada nos } \\
\text { proporcionó su número de teléfono personal, en caso necesitemos } \\
\text { contactarnos con ella directamente. }\end{array}$ \\
\hline $\begin{array}{c}\text { Conclusión } \\
\text { general de la } \\
\text { entrevista del } \\
\text { gerente de } \\
\text { RRHH }\end{array}$ & $\begin{array}{l}\text { La aplicación de la entrevista nos ayudó para conocer la información } \\
\text { sobre el centro de contacto donde ella trabaja. El personal que contrata } \\
\text { por cada campaña, el motivo porqué renuncian, la cantidad de asesores } \\
\text { telefónicos que tiene a su cargo y la responsabilidad que tiene para } \\
\text { mantener y evitar la fuga de esos talentos. }\end{array}$ \\
\hline
\end{tabular}




\begin{tabular}{|c|c|}
\hline $\begin{array}{l}\text { Contexto } \\
\text { /Segmento }\end{array}$ & Ficha Filtro \\
\hline $\begin{array}{l}\text { Experiencia en el } \\
\text { sector de Centro } \\
\text { de Contacto }\end{array}$ & $\begin{array}{l}\text { La entrevistada trabaja desde el } 2015 \text { para HDC. En este Centro de } \\
\text { Contacto existen } 500 \text { asesores telefónicos. El perfil del asesor } \\
\text { telefónico: Secundaria completa, estudiantes técnicos y estudios } \\
\text { inconclusos, que tengan habilidades blandas, técnicas de } \\
\text { negociación, tolerantes, con o sin experiencia, mayores de } 18 \text { años. } \\
\text { Las unidades especializadas son: Atención al cliente, ventas y } \\
\text { cobranzas. HDC se especializa más en cobranzas. }\end{array}$ \\
\hline $\begin{array}{c}\text { Información de } \\
\text { las variables de } \\
\text { estudio }\end{array}$ & $\begin{array}{l}\text { Los horarios son rotativos en el área de cobranzas y ventas; atención } \\
\text { al cliente son fijos. Los contratos son sujetos a modalidad por servicio } \\
\text { específico; por inicio de campaña o plan piloto y se renuevan cada } 4 \\
\text { a } 6 \text { meses. El sueldo base para los asesores categoría Junior (sin } \\
\text { experiencia) es de } \mathrm{S} / 850.00 \text { y las comisiones aproximadamente son } \\
\text { de } \mathrm{S} / 200.00 \text { y } \mathrm{S} / 400.00 \text { para el área de cobranzas y en ventas puede } \\
\text { variar un poco más, dependiendo el nivel de negociación, no tienen } \\
\text { tope. Para los asesores categoría Senior (con experiencia) el sueldo } \\
\text { base es de } \mathrm{S} / 1,000.00 \text { y aparte sus comisiones en promedio son de } \mathrm{S} / \text {. } \\
1500.00 \text { en el área de ventas. }\end{array}$ \\
\hline $\begin{array}{l}\text { Factores que } \\
\text { afectan la } \\
\text { rotación de } \\
\text { asesores } \\
\text { telefónicos }\end{array}$ & $\begin{array}{l}\text { Al } 60 \% \text { de asesores telefónicos se les renueva de manera temporal y } \\
40 \% \text { pueden lograr una renovación indeterminada de acuerdo a } \\
\text { resultados. Los motivos más frecuentes de renuncia son por cese } \\
\text { forzado debido a la desvinculación, no renovación o no superación } \\
\text { de periodo de prueba. La media de permanencia de los asesores } \\
\text { telefónicos es de dos años. El índice de rotación mensual es de } 14 \% \\
\text { a } 15 \% \text {. Los asesores telefónicos, sí están bien remunerados, porque } \\
\text { tienen todos los beneficios de ley y lo que se les paga está de acuerdo } \\
\text { con el mercado. }\end{array}$ \\
\hline $\begin{array}{c}\text { Información } \\
\text { Adicional }\end{array}$ & $\begin{array}{l}\text { Indica que en su Centro de Contacto, hay mayor porcentaje de } \\
\text { participación de mujeres en comparación con los varones. La } \\
\text { mayoría de las mujeres son más comprometidas y responsables en } \\
\text { sus labores. Además, indica que por la naturaleza del servicio, el } \\
\text { trabajo en Centros de Contacto es temporal, lo cual ayuda a cubrir } \\
\text { ciertas necesidades básicas de manera momentánea. }\end{array}$ \\
\hline
\end{tabular}


Tabla 22. Observación de la entrevista (Segmento C, Gerente)

\begin{tabular}{|c|l|}
\hline $\begin{array}{c}\text { Contexto } \\
\text { Segmento }\end{array}$ & \multicolumn{1}{c|}{ Ficha Filtro } \\
\hline $\begin{array}{c}\text { Observaciones } \\
\text { antes de la } \\
\text { entrevista }\end{array}$ & $\begin{array}{l}\text { La entrevista estuvo previamente coordinada a través de correos } \\
\text { electrónicos, para el viernes } 06 \text { de octubre } 2017 \text { a las 03:00 pm, en la } \\
\text { oficina ubicada en calle Capitán Astete } \mathrm{N}^{\circ} 118 \text { en el distrito de La } \\
\text { Victoria. } \\
\text { La entrevistada nos recibió en su oficina, un lugar formal y cómodo. }\end{array}$ \\
\hline $\begin{array}{c}\text { Observaciones } \\
\text { durante la } \\
\text { entrevista }\end{array}$ & $\begin{array}{l}\text { La persona entrevistada accedió a responder a todas nuestras preguntas } \\
\text { de investigación, tiene clasificado a su personal por diferentes rangos } \\
\text { de edades y perfiles. } \\
\text { La entrevistada cuenta con bastante experiencia en el tema de rotación } \\
\text { de asesores telefónicos de su empresa. Se mostró muy amable y segura } \\
\text { de la información brindada. }\end{array}$ \\
\hline $\begin{array}{c}\text { Observaciones } \\
\text { después de la } \\
\text { entrevista }\end{array}$ & $\begin{array}{l}\text { La entrevista tuvo una duración de } 30 \text { minutos. } \\
\text { La entrevistada nos comentó que podría apoyarnos para facilitar } \\
\text { entrevistas a algunos de sus asesores del Centro de Contacto, pero por } \\
\text { falta de tiempo, de cierres de mes y trimestre no se pudo concretar } \\
\text { dichas entrevistas. }\end{array}$ \\
\hline $\begin{array}{c}\text { Conclusión } \\
\text { general de la } \\
\text { entrevista con } \\
\text { la Jefa de } \\
\text { Recursos } \\
\text { Humanos }\end{array}$ & $\begin{array}{l}\text { Tiene bastante conocimiento y experiencia en cuanto a los diferentes } \\
\text { perfiles que requieren las empresas para la contratación de los asesores } \\
\text { telefónicos, debido a las exigencias que se presentan en el mercado } \\
\text { laboral, La línea de carrera que se ofrece en este sector es muy limitado, } \\
\text { por ello, la rotación es constante. }\end{array}$ \\
\hline
\end{tabular}


Tabla 23. Ficha de la entrevista (Segmento C, Gerente)

\begin{tabular}{|c|c|}
\hline $\begin{array}{l}\text { Contexto } \\
\text { /Segmento }\end{array}$ & Ficha Filtro \\
\hline $\begin{array}{l}\text { Experiencia en el } \\
\text { sector de Centro } \\
\text { de Contacto }\end{array}$ & $\begin{array}{l}\text { La entrevistada trabaja desde el } 2009 \text { para MTG. En este Centro de } \\
\text { Contacto existen } 60 \text { asesores telefónicos. Tiene clasificado a su } \\
\text { personal: Generación } \mathrm{Z} \text { de } 18 \text { a } 23 \text { años, Generación milenios de } 24 \\
\text { a } 32 \text { años. } \\
\text { Perfil del asesor depende del requerimiento del cliente: Si es perfil } \\
\text { básico requieren asesores telefónicos con/sin experiencia, con } \\
\text { secundaria completa y que tengan habilidades blandas. Si es perfil } \\
\text { avanzado, se requiere asesores telefónicos con/sin experiencia y que } \\
\text { sean egresados, bachilleres, con dominio de office. Mientras el } \\
\text { requerimiento sea más exigente tendrán un mejor sueldo. }\end{array}$ \\
\hline $\begin{array}{c}\text { Información de } \\
\text { las variables de } \\
\text { estudio }\end{array}$ & $\begin{array}{l}\text { En el Centro de Contacto no tienen establecido un horario rotativo, } \\
\text { ni horario nocturno, sus horarios son fijos. Los turnos de trabajo se } \\
\text { establecen de } 48 \text { horas semanales. Los contratos se renuevan cada } \\
\text { seis meses. } \\
\text { Sobre la política de remuneración se establece según el sueldo perfil } \\
\text { básico } S / 900.00 \text { más las comisiones como monto máximo } \mathrm{S} / 200.00 \text {. } \\
\text { Sueldo perfil avanzado } \mathrm{S} / 1,100.00 \text { más las comisiones como monto } \\
\text { máximo S/600.00. } \\
\text { Realizan actividades de integración, ya que nos comenta que es } \\
\text { necesario mantener motivados a los asesores telefónicos para } \\
\text { fomentar su productividad laboral. }\end{array}$ \\
\hline $\begin{array}{l}\text { Factores que } \\
\text { afectan la } \\
\text { rotación de } \\
\text { asesores } \\
\text { telefónicos }\end{array}$ & $\begin{array}{l}\text { La entrevistada nos indica que el índice de rotación al cierre del } 2016 \\
\text { terminó en } 13 \% \text {. Actualmente, el índice de rotación al cierre de } \\
\text { Setiembre } 2017 \text { es de } 11 \% \text {. Indica que este índice puede ser muy } \\
\text { variable. } \\
\text { Existe una mayor rotación en el área de ventas, debido a que los } \\
\text { asesores telefónicos no logran concretar sus metas establecidas. } \\
\text { El tiempo de permanencia de un asesor telefónico es de } 3 \text { a } 6 \text { meses. } \\
\text { Las renuncias voluntarias formales y abandonos de trabajo de los } \\
\text { asesores telefónicos se da entre un } 70 \% \text { y } 30 \% \text {, respectivamente. }\end{array}$ \\
\hline $\begin{array}{c}\text { Información } \\
\text { Adicional }\end{array}$ & $\begin{array}{l}\text { La remuneración puede ser baja, pero si el ambiente o clima laboral } \\
\text { es muy bueno, el asesor permanece. Si la remuneración es baja y } \\
\text { clima no es bueno, el asesor abandona el trabajo y busca nuevas } \\
\text { oportunidades laborales. } \\
\text { El mayor índice de rotación se da entre los jóvenes de la generación } \\
\text { milenios y Z. }\end{array}$ \\
\hline
\end{tabular}


Tabla 24. Observaciones de la entrevista (Segmento D, Institución Privada)

\begin{tabular}{|c|c|}
\hline $\begin{array}{l}\text { Contexto } \\
\text { /Segmento }\end{array}$ & Especialista del Sector \\
\hline $\begin{array}{l}\text { Observaciones } \\
\text { antes de la } \\
\text { entrevista }\end{array}$ & $\begin{array}{l}\text { La entrevista con el director de APECCO, estuvo previamente } \\
\text { coordinada para el miércoles } 20 \text { de setiembre } 2017 \text { a las } 8: 30 \text { am, } \\
\text { en la oficina ubicada en calle Garcilaso de la Vega N } 2640 \text { en el } \\
\text { distrito de Lince, sede administrativa de HDC BPO service. }\end{array}$ \\
\hline $\begin{array}{l}\text { Observaciones } \\
\text { durante la } \\
\text { entrevista }\end{array}$ & $\begin{array}{l}\text { El lugar donde se desarrolló la entrevista era una sala de reunión } \\
\text { pequeña, formal, cómoda, equipada con una moderna tecnología } \\
\text { (proyector, laptop, aire acondicionado, sillas ergonómicas, entre } \\
\text { otros). } \\
\text { El entrevistado accedió a responder todas nuestras preguntas, tenía } \\
\text { mucha predisposición, se lo notaba tranquilo, muy seguro de sí } \\
\text { mismo, sus respuestas fueron claras; podemos confirmar que el } \\
\text { entrevistado cuenta con amplios conocimientos sobre el sector. } \\
\text { Además, nos brindó información sobre una visión a futuro de esta } \\
\text { industria. En una oportunidad la entrevista fue interrumpida por } \\
\text { unos minutos. }\end{array}$ \\
\hline $\begin{array}{l}\text { Observaciones } \\
\text { después de la } \\
\text { entrevista }\end{array}$ & $\begin{array}{l}\text { El entrevistado nos proporcionó su número de teléfono personal, } \\
\text { en caso necesitemos contactarnos con él directamente, a fin de } \\
\text { apoyarnos para ser el medio con otros Centros de Contacto y poder } \\
\text { concretar una entrevista y continuar con el tema de investigación. }\end{array}$ \\
\hline $\begin{array}{l}\text { Conclusión } \\
\text { general de la } \\
\text { entrevista con el } \\
\text { especialista }\end{array}$ & $\begin{array}{l}\text { La entrevista tuvo una duración de } 30 \text { minutos. } \\
\text { El entrevistado cuenta con basta experiencia en el sector, pero el } \\
\text { tiempo fue muy limitado para poder extendernos, ya que tenía una } \\
\text { reunión con una junta directiva programada. Sin embargo se } \\
\text { completó con la guía de preguntas establecidas. }\end{array}$ \\
\hline
\end{tabular}


Tabla 25. Ficha de la entrevista (Segmento D, Institución Privada)

\begin{tabular}{|c|l|}
\hline $\begin{array}{c}\text { Contexto } \\
\text { /Segmento }\end{array}$ & Ficha Filtro \\
\hline $\begin{array}{c}\text { Experiencia en } \\
\text { el sector de } \\
\text { Centro de } \\
\text { Contacto }\end{array}$ & $\begin{array}{l}\text { Indica que la materia prima de la industria del Centro de Contacto es } \\
\text { el recurso humano, el medio de contacto es sólo vía telefónica y las } \\
\text { redes sociales. Lo que se busca en el Centro de Contacto es mejorar, } \\
\text { generar mejores prácticas. Servicio de inbound y outbound, se ofrece } \\
\text { en los siguientes rubros: atención al cliente, backoffice, cobranzas, } \\
\text { outshore, todas las empresas dedicadas a este rubro hacen de todo. } \\
\text { Existen 20 empresas asociadas a APECCO con tendencia al BPO. }\end{array}$ \\
$\begin{array}{c}\text { Información de } \\
\text { las variables de } \\
\text { estudio }\end{array}$ & $\begin{array}{l}\text { La edad promedio de un asesor telefónico se encuentra entre los 18 y } \\
\text { experiencia laboral. Con respecto a los horarios de trabajo son } \\
\text { flexibles, son fijos, desde el inicio del contrato se le confirma su } \\
\text { horario al asesor telefónico, puede ser un horario en la mañana, en la } \\
\text { tarde o de amanecida. La remuneración base es de S/850.00. El tiempo } \\
\text { de permanencia de un asesor es de 6 meses. }\end{array}$ \\
\hline $\begin{array}{c}\text { Factores que } \\
\text { afectan la } \\
\text { rotación de } \\
\text { asesores } \\
\text { telefónicos }\end{array}$ & $\begin{array}{l}\text { Refiere que el sector de servicios de Centro de Contacto tiene } \\
\text { potencial de crecimiento, las empresas que conforman APECCO tiene } \\
\text { un 70\% de participación en el mercado. En la industria del contact } \\
\text { center la rotación anual ha sido de 19\% al cierre del año 2016. } \\
\text { La proyección al 2020 del sector tiene un crecimiento continuo y la } \\
\text { captación de más jóvenes sin experiencia, ayudará a generar mayor } \\
\text { empleabilidad para que aprendan y se desarrollen profesionalmente. }\end{array}$ \\
\hline $\begin{array}{l}\text { La rotación en este sector se debe a que los jóvenes no tienen una } \\
\text { estabilidad laboral y responsabilidad por mantener un trabajo estable, } \\
\text { ya que solo buscan satisfacer sus necesidades temporales. Por la } \\
\text { limitación del tiempo no se extendió la entrevista. }\end{array}$ \\
\hline
\end{tabular}


Tabla 26. Observaciones de la entrevista (Segmento D, David Edery Muñoz)

\begin{tabular}{|c|l|}
\hline $\begin{array}{c}\text { Contexto } \\
\text { Segmento }\end{array}$ & Especialista del Sector \\
\hline $\begin{array}{c}\text { Observaciones } \\
\text { antes de la } \\
\text { entrevista }\end{array}$ & $\begin{array}{l}\text { La entrevista con el Gerente de Exportación de Servicios de } \\
\text { PROMPERÚ, estuvo previamente coordinada para el miércoles } 24 \text { de } \\
\text { octubre 2017 a las 09:30 am, en la oficina ubicada en calle 21 al lado } \\
\text { del Ministerio del Interior en el distrito de San Isidro. }\end{array}$ \\
\hline $\begin{array}{c}\text { Observaciones } \\
\text { durante la } \\
\text { entrevista }\end{array}$ & $\begin{array}{l}\text { El lugar donde se desarrolló la entrevista era una sala de reunión formal, } \\
\text { cómoda y completamente equipada con una moderna tecnología y } \\
\text { de experiencia en PROMPERÚ, sus respuestas fueron claras, podemos } \\
\text { confirmar que el entrevistado cuenta con amplios conocimientos sobre } \\
\text { el sector de exportación de servicios de los Centros de Contacto a nivel } \\
\text { nacional. Además, nos brindó información sobre una visión a futuro de } \\
\text { esta industria. }\end{array}$ \\
\hline $\begin{array}{c}\text { Observaciones } \\
\text { después de la } \\
\text { entrevista }\end{array}$ & $\begin{array}{l}\text { El entrevistado nos mencionó que nos podría proporcionar alguna } \\
\text { información adicional, en caso lo requeríamos y se podía coordinar } \\
\text { directamente con su asistente. }\end{array}$ \\
\hline $\begin{array}{c}\text { Conclusión } \\
\text { general de la } \\
\text { entrevista }\end{array}$ & $\begin{array}{l}\text { La entrevista tuvo una duración de 40 minutos. } \\
\text { El entrevistado indica que la tasa de rotación se encuentra en un 18 \% } \\
\text { al cierre del último año 2016. } \\
\text { Los factores que considera que puede afectar esta rotación son: Los } \\
\text { Centros de Contacto al tener un menor ingreso, tienen que restar sus } \\
\text { costos. Lo primero que van a realizar es la reducción de mano de obra, } \\
\text { esto representa el 85\% del costo de la misma operación. } \\
\text { El sueldo promedio máximo al que puede aspirar un asesor telefónico } \\
\text { es de S/ 1,000.00 a S/1,400.00. }\end{array}$ \\
\hline
\end{tabular}


Tabla 27. Ficha de la entrevista (Segmento D, Institución Pública)

\begin{tabular}{|c|l|}
\hline $\begin{array}{c}\text { Contexto } \\
\text { /Segmento }\end{array}$ & \multicolumn{1}{c|}{ Ficha filtro } \\
\hline $\begin{array}{c}\text { Experiencia } \\
\text { en el sector de } \\
\text { Centro de } \\
\text { Contacto }\end{array}$ & $\begin{array}{l}\text { El sector de Centros de Contacto ha ido en incremento, actualmente } \\
\text { cuenta con } 38 \text { mil puestos de asesores telefónicos aproximadamente al } \\
\text { cierre del primer trimestre del año } 2017 .\end{array}$ \\
\hline $\begin{array}{c}\text { Información } \\
\text { de las } \\
\text { variables de } \\
\text { estudio }\end{array}$ & $\begin{array}{l}\text { Las empresas no han madurado los servicios que vienen ofreciendo, } \\
\text { mayormente todo es telecomunicaciones, fidelización, ventas, entre } \\
\text { otros. Este tipo de servicio ya en el mundo se ha comoditizado, quiere } \\
\text { decir, que ya es un servicio muy común. Pocos Centros de Contacto } \\
\text { están dedicados a la fidelización, help desk, que son otros tipos de } \\
\text { servicio de mayor valor agregado y que pocos están brindando. }\end{array}$ \\
\hline $\begin{array}{c}\text { Factores que } \\
\text { afectan la } \\
\text { rotación de } \\
\text { asesores } \\
\text { telefónicos }\end{array}$ & $\begin{array}{l}\text { La tasa de crecimiento se ha desacelerado, porque ya no aparecen } \\
\text { nuevos Centros de Contacto, en su mayoría se están fusionando, puesto } \\
\text { que, cuentan con problemas de infraestructura, los lugares céntricos } \\
\text { están copados para que pueden instalar sus operaciones. }\end{array}$ \\
\hline $\begin{array}{c}\text { Información } \\
\text { Adicional }\end{array}$ & $\begin{array}{l}\text { y no todos ofrezcan los mismos servicios, se podría disminuir la } \\
\text { problemática. La rotación puede generar más inestabilidad laboral. } \\
\text { El principal problema que tiene los Centros de Contacto cuando se va } \\
\text { un asesor telefónico, es realizar el reclutamiento nuevamente, por ello, } \\
\text { es mejor retenerlos a través de incentivos, la labor es estresante y } \\
\text { algunos ambientes no son los adecuados. Las condiciones laborales } \\
\text { también son un factor que podría generar la rotación. }\end{array}$ \\
\hline
\end{tabular}


Tabla 28. Observaciones de la entrevista (Segmento D, Abogado laboralista)

\begin{tabular}{|c|l|}
\hline $\begin{array}{c}\text { Contexto } \\
\text { /Segmento D }\end{array}$ & \multicolumn{1}{c|}{ Especialista del Sector } \\
\hline $\begin{array}{c}\text { Observaciones } \\
\text { antes de la } \\
\text { entrevista }\end{array}$ & $\begin{array}{l}\text { La entrevista con el abogado y docente de derecho laboral, estuvo } \\
\text { previamente coordinada para el martes 24 de octubre 2017 a la } \\
01: 00 \text { pm, en un restaurante de Plaza Lima Norte, en el distrito de } \\
\text { San Martin de Porres. }\end{array}$ \\
\hline $\begin{array}{c}\text { Observaciones } \\
\text { durante la } \\
\text { entrevista }\end{array}$ & $\begin{array}{l}\text { Se procedió a comentarle en qué consistía nuestra investigación y } \\
\text { a exponerle algunas preguntas. El entrevistado mostraba mucha } \\
\text { predisposición, además cuenta con amplios conocimientos sobre el } \\
\text { sistema de contratación en los Call Center. Comentó haber } \\
\text { trabajado en diferentes empresas y estar a cargo de las diferentes } \\
\text { renovaciones de contratos aplicados en los asesores telefónicos. El } \\
\text { entrevistado estaba un poco nervioso en la entrevista porque le } \\
\text { incomodaba la filmación. A pesar de ello se pudo concretar la } \\
\text { entrevista sin ningún inconveniente adicional. }\end{array}$ \\
\hline $\begin{array}{c}\text { Observaciones } \\
\text { después de la } \\
\text { entrevista }\end{array}$ & $\begin{array}{l}\text { El entrevistado mencionó que nos podría proporcionar alguna } \\
\text { información adicional, en caso lo requeríamos. Lo hicimos } \\
\text { posteriormente a través de su asistente. El entrevistado después de } \\
\text { haber contado su experiencia en el ámbito laboral, nos recomendó } \\
\text { entrevistar a otros expertos en el tema. }\end{array}$ \\
\hline $\begin{array}{c}\text { Conclusión } \\
\text { general de la } \\
\text { entrevista }\end{array}$ & $\begin{array}{l}\text { La información obtenida en la entrevista fue muy relevante debido } \\
\text { a que se pudo conocer el tipo de contrato que aplican en los } \\
\text { diferentes centros de contacto, la importancia que tiene el asesor } \\
\text { telefónico al momento de firmar su contrato y sus deberes que } \\
\text { muchos por desconocimiento, no reclaman los beneficios que les } \\
\text { corresponden ante despidos arbitrarios. }\end{array}$ \\
\hline
\end{tabular}


Tabla 29. Ficha de la entrevista (Segmento D, Abogado laboralista)

\begin{tabular}{|c|c|}
\hline $\begin{array}{l}\text { Contexto } \\
\text { /Segmento }\end{array}$ & Ficha Filtro \\
\hline $\begin{array}{l}\text { Experiencia en el } \\
\text { sector de Centro } \\
\text { de Contacto }\end{array}$ & $\begin{array}{l}\text { El abogado nos indica que los Call Center básicamente, brindan } \\
\text { servicios a terceros. Las empresas que contratan a personas para } \\
\text { realizar este tipo de trabajo están dedicadas a la intermediación } \\
\text { laboral, son personas que pueden designar algunos trabajadores a } \\
\text { ciertas empresas. }\end{array}$ \\
\hline $\begin{array}{l}\text { Información de } \\
\text { las variables de } \\
\text { estudio }\end{array}$ & $\begin{array}{l}\text { En la mayoría de los casos los asesores son contratados en menos de } \\
\text { dos meses. } \\
\text { El sueldo promedio de un asesor telefónico no está acorde con el } \\
\text { mercado, ya que la remuneración mínima vital es baja en el Perú. } \\
\text { Los horarios rotativos van de acuerdo con el contrato que tengan con } \\
\text { el cliente usuario, en todo caso las empresas de Call Center deben dar } \\
\text { una comunicación clara desde el inicio, para que el asesor no tenga } \\
\text { ninguna duda sobre sus turnos de trabajo en un periodo determinado. }\end{array}$ \\
\hline $\begin{array}{l}\text { Factores que } \\
\text { afectan la } \\
\text { rotación de } \\
\text { asesores } \\
\text { telefónicos }\end{array}$ & $\begin{array}{l}\text { Falta de conocimiento de las condiciones laborales, se debe indicar a } \\
\text { los jóvenes los términos de sus contratos. } \\
\text { El índice de rotación es alto, mayormente entre jóvenes de } 18 \text { a } 20 \\
\text { años, y uno de los motivos de rotación es por despido justificado o } \\
\text { término de contrato. } \\
\text { El sueldo promedio no está acorde con el del mercado, ya que la } \\
\text { remuneración mínima vital es baja en el Perú. } \\
\text { Los horarios rotativos van de acuerdo con el contrato que tengan con } \\
\text { el cliente usuario. }\end{array}$ \\
\hline $\begin{array}{c}\text { Información } \\
\text { Adicional }\end{array}$ & $\begin{array}{l}\text { Mayor conocimiento de las condiciones laborales se debe indicar a } \\
\text { los jóvenes los términos de sus contratos. } \\
\text { Falta fiscalización laboral en las empresas de Call Center, se debería } \\
\text { promover ésta, con el fin de evitar muchas vulneraciones laborales. }\end{array}$ \\
\hline
\end{tabular}

